\title{
UCL: uma linguagem de comunicação para agentes de software
}

\author{
Carlos Alberto Estombelo Montesco
}

Orientador:

Prof. Dr. Dilvan de Abreu Moreira

Dissertação apresentada ao Instituto de Ciências Matemáticas e de Computação ICMC-USP, como parte dos requisitos para obtenção do titulo de Mestre em Ciências de Computação e Matemática Computacional.

$$
\begin{gathered}
\text { USP - São Carlos } \\
\text { Dezembro/2001 }
\end{gathered}
$$

Data da Defesa:

$22 / 11 / 2001$

Revisada)

Visto do Orientador Dilucu lloveina. 


\title{
$\mathrm{UCL}$ - Uma Linguagem de Comunicação para Agentes de Software
}

\author{
Carlos Alberto Estombelo Montesco
}

Orientador

Prof. Dr. Dilvan de Abreu Moreira

\begin{abstract}
Dissertaçäo apresentada ao Instituto de Ciências Matemáticas e de Computação, da Universidade de São Paulo - USP, como parte dos requisitos para obtenção do título de Mestre em Ciências - Área de Ciências de Computaçăo e Matemática Computacional.
\end{abstract}

São Carlos

Outubro de 2001 
"Being a scientist means living on the botderline between your competence and your incompetence, if you always feel competent, you aren't doing your job. -Carlos Bustamante" 


\section{AGRADECIMENTOS}

A meus pais, Andrés e Eufemia por acreditar em mi todo este tempo, pelo apoio, carinho e amor oferecidos à distancia desde Arequipa.

A meu irmão, Richard pela força, apoio e motivação que sempre colocou nas minhas decisões em todo momento.

Ao professor Dilvan, que acreditou na minha capacidade para realizar meu mestrado. Obrigado pela ajuda nos momentos dificeis e pela amizade. Sem duvida aprendi muitas coisas valiosas que estarão presentes na minha vida.

Aos amigos que sempre estão por perto, Alex, Percy, Pastor, Eduardo, Ernesto, Govi, Miluska, Cesar, Ursula, Christian, Patricia, Guillermo, Juan Carlos, Jorgito. Sem eles seria muito mais dificil este caminho.

A todos os colegas que dividiram seu tempo comigo durante todo o mestrado. Em especial ao pessoal de Minas Gerais, Obrigado a vocês por compartir sua vida comigo, Débora, Iris, Elaine, Thiago, Stênio, Werley ... com vocês conheci e entendi as palavras "gente boa!".

À Marilia, Beth e Laura, pela paciência e por estarem sempre prontas a me atender.

À CNPq (Conselho Nacional de Desenvolvimento Científico e Tecnológico), pelo apoio financeiro para a realização deste trạbalho. 


\section{ÍNDICE}

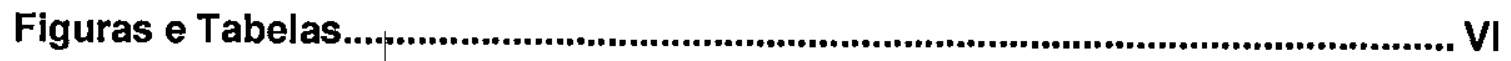

RESUMO .......................................................................................................... VIII

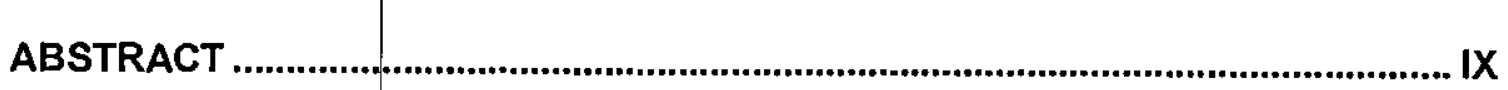

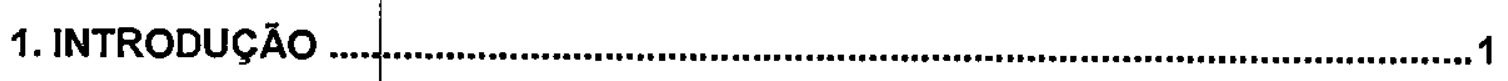

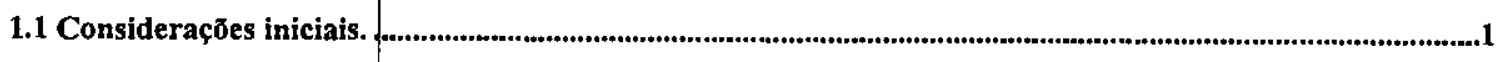

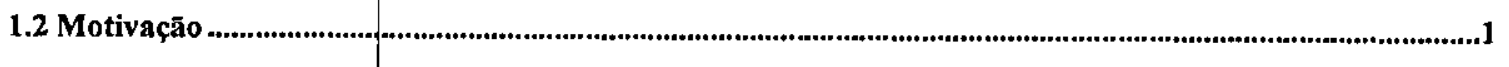

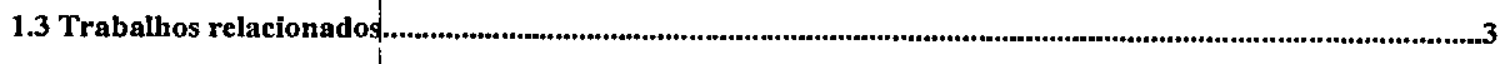

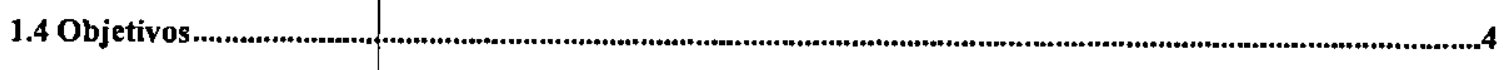

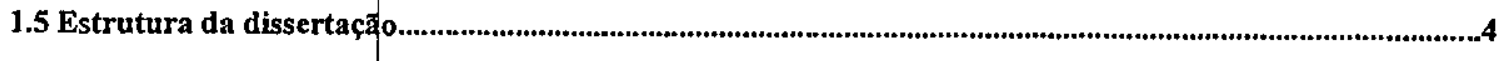

2. COMUNICAÇĀO ENTRE AGENTES DE SOFTWARE...........................................6

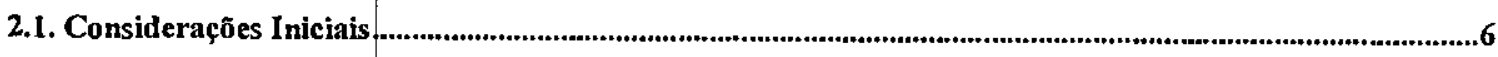

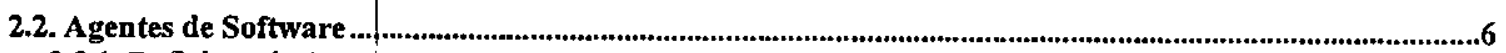

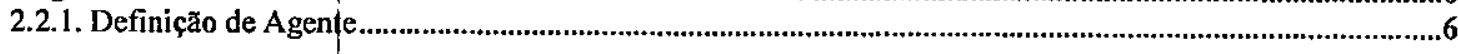

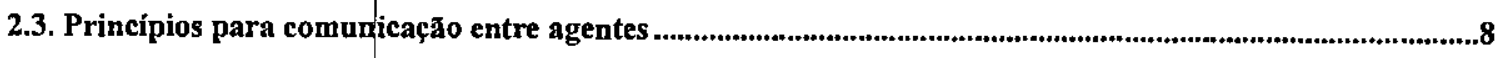

2.4. Especificaçōes de uma linguagem de comunicação para agentes.................................................................10

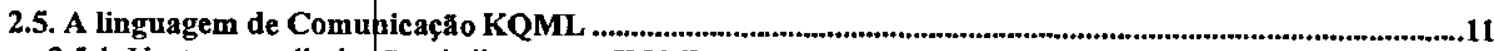

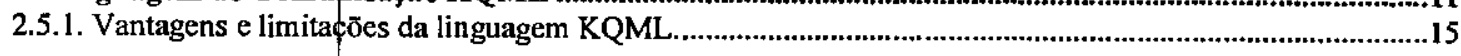

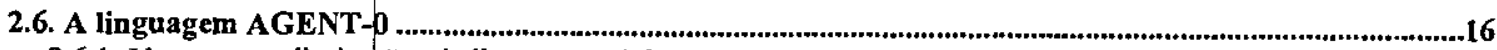

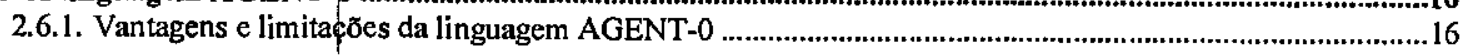

2.7. Linguagens de comunjẹçåa para Agentes Móveis ..........................................................................................17

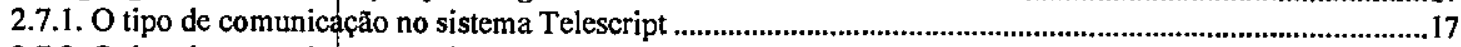

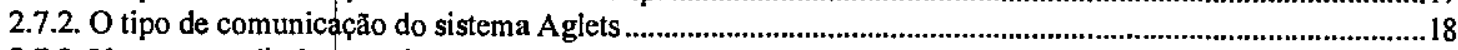

2.7.3. Vantagens e limitaçঠes da comunicação entre Agentes Móveis...............................................................19

2.8. A linguagem FIPA-A

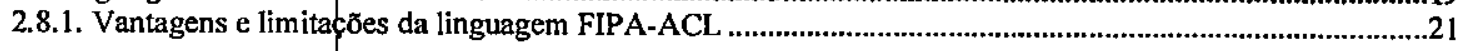

2.9. Uma proposta para uma ACL com ênfase no ambiente social.......................................................................21

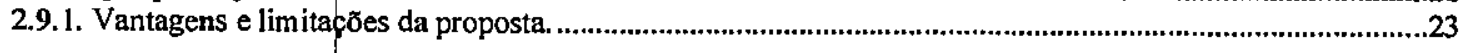

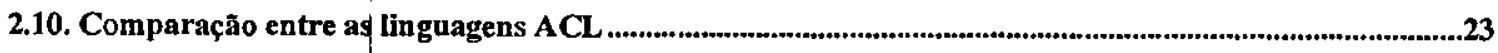

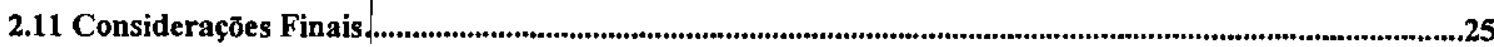


3. ONTOLOGIAS PARA AGENTES...............................................................27

3.1 Considerą̧⿸丆es iniciais .

3.2 Definição e Aplicaçāo de Ontologias .................................................................................................................27

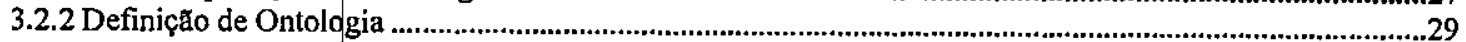

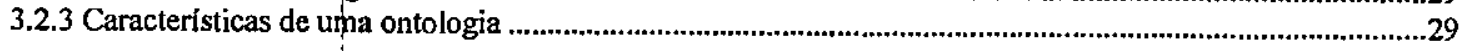

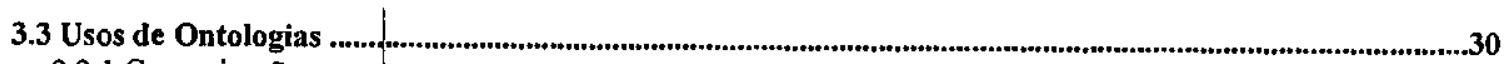

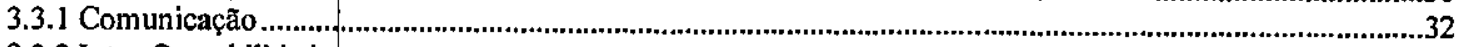

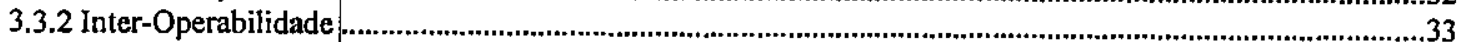

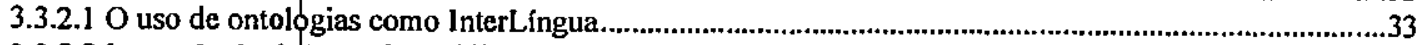

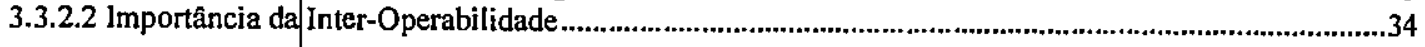

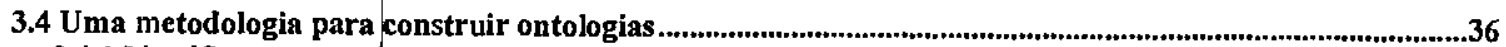

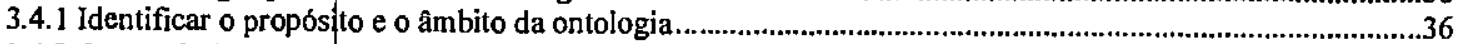

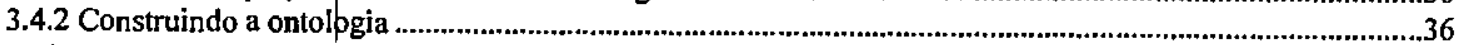

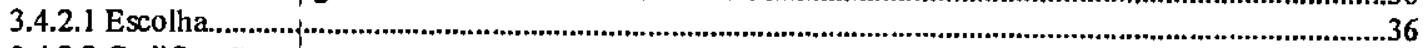

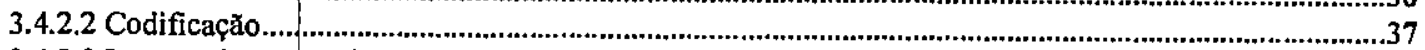

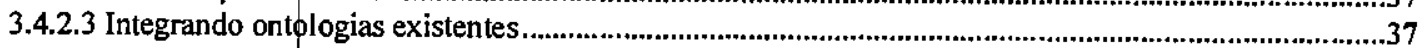

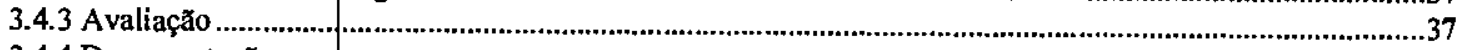

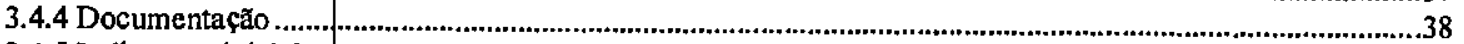

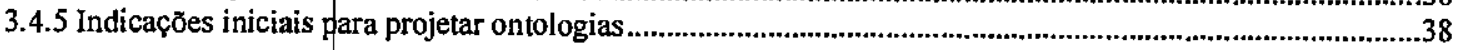

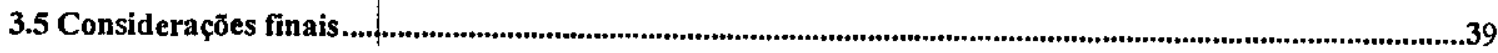

4. COMUNICAÇĀO ĖNTRE AGENTES DE SOFTWARE NA INTERNET ................40

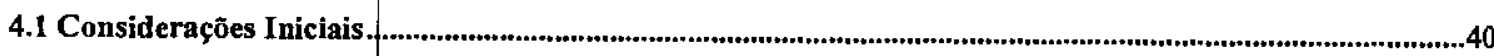

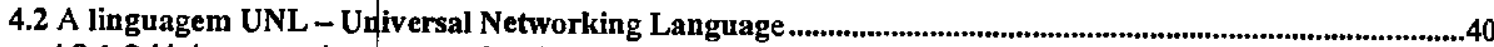

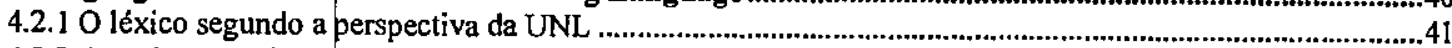

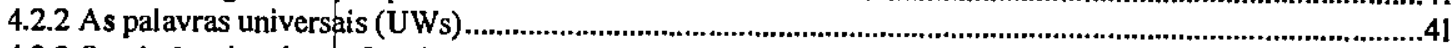

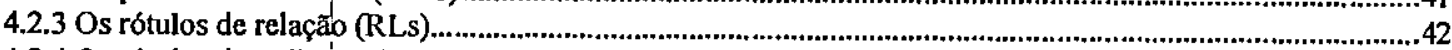

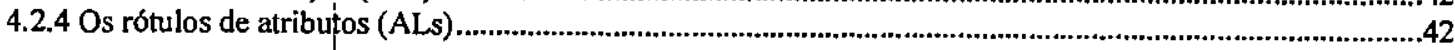

4.3 A meta-linguagem XML - Extensible MarkUp Language ..........................................................................43

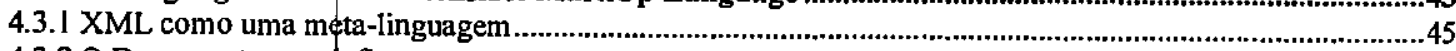

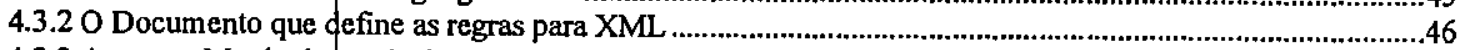

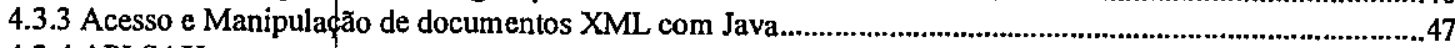

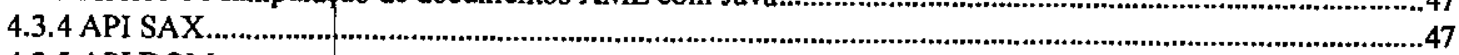

4.3.5 API DOM

4.4 Representação de sentenç̧as em linguagem natural ....................................................................................50

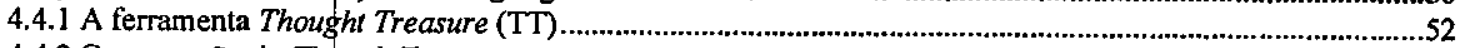

4.4.2 Comparação do Thought Treasure com outros sistemas ..........................................................................55

4.5 Considerações finais ....

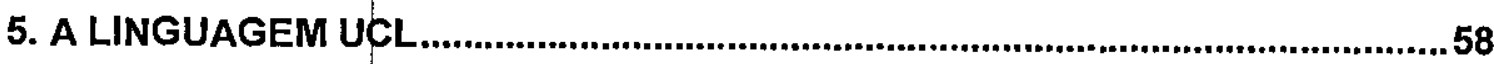

5.1 Considerą̧⿰̃es iniciais

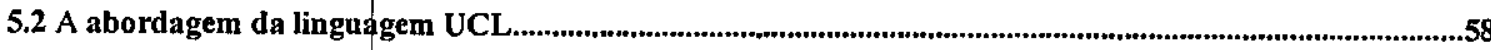

5.3 Metodologia utilizada.

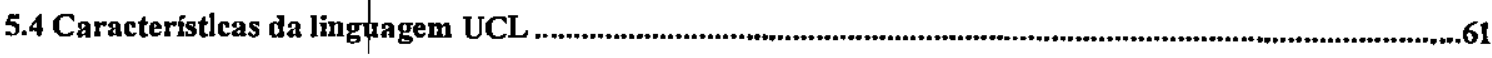




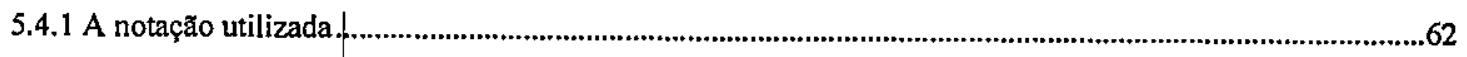

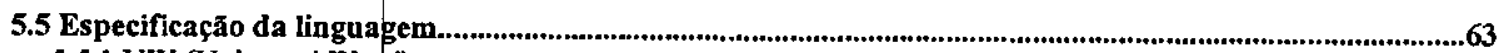

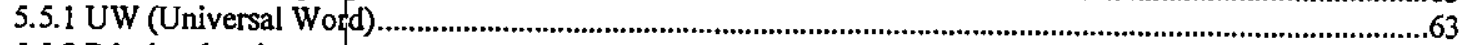

5.5.2 Rótulos de relação .

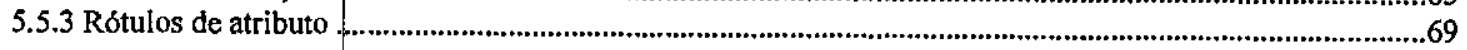

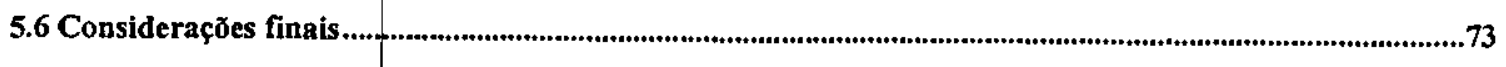

6. UM ENCONVERTER-DECONVERTER UCL...................................................75

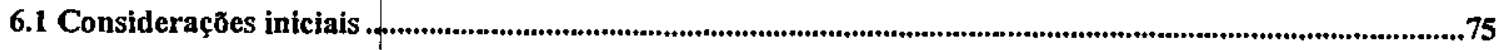

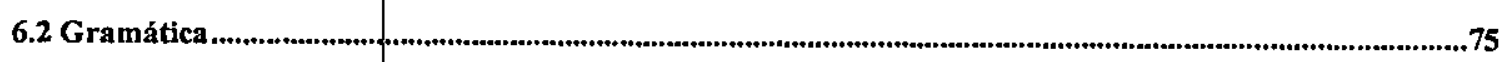

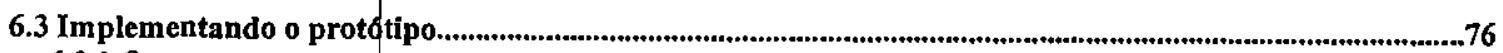

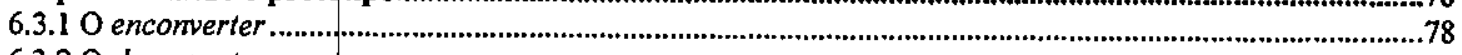

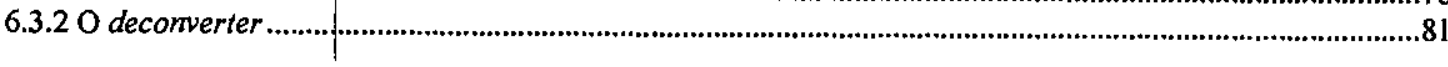

6.4 Arquitetura de um sistẹma de comunicação em UCL ..............................................................................85

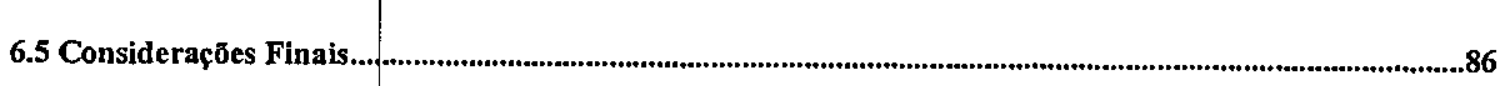

7. CONCLUSÃO

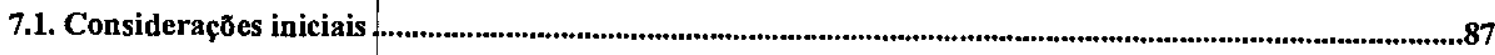

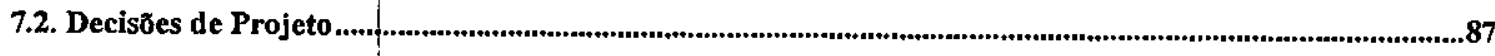

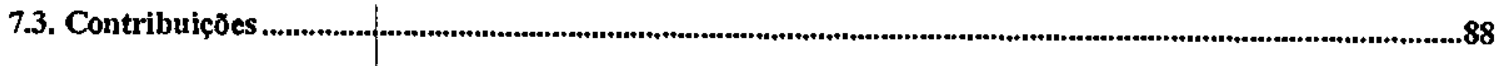

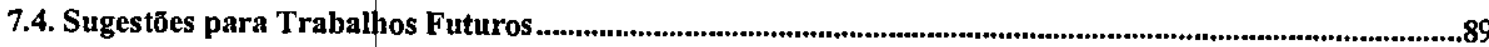

7.5. Consideraçס̃es Finais ...

APÊNDICE A - DESCRIÇÃO DA LINGUAGEM UNIVERSAL NETWORKING

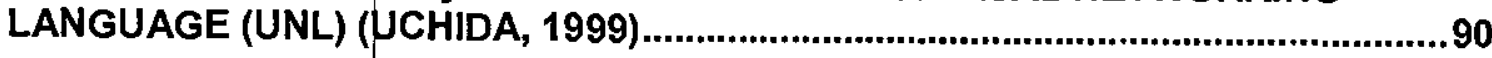

APÊNDICE B - DTD|DA UNIVERSAL COMMUNICATION LANGUAGE ..................93

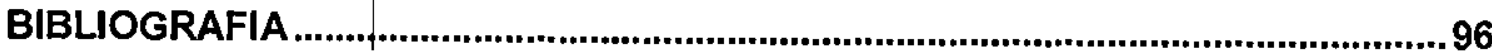




\section{Figuras e Tabelas}

Figura 2.1. Estrutura das três camadas KQML 14

Figura 2.2. Arquitetura do sistema Telescript. 18

Figura 2.3. A Arquitetura Aglet e modelo de comunicação. 19

Figura 2.4. Espaço de płojeto das linguagens de comunicação de agente 22

Figura 3.1 Usos de ontologias. 31

Figura 3.2 Ontologia colmo Interlíngua 34

Figura 3.3 Exemplo de uso de ontologia como interlíngua. 35

Figura 4.1 Sistema baseado em XML. 46

Figura 4.2 Estrutura do HTML utilizado no exemplo.

Figura 4.3a Estrutura basseada em árvore (API DOM). 50

Figura 4.3b Estrutura baseada em evento (API SAX). 50

Figura 4.4 Associação da ontologia com a linguagem natural. 52

Figura 4.5 Formato do banco de dados do Thought Treasure 53

Figura 4.6 Relações em Thought Treasure.

Figura 4.7 Asserções em ThoughtTreasure.

Figura 5.1 Sintaxe gemal de uma Universal Word 63

Figura 5.2 Definição de/conceitos em um documento XML 64

Figura 5.3 Sintaxe geral de um Rótulo de relação. 65

Figura 5.4 Definição de Rótulos de relação em um documento XML 69

Figura 5.5 Sintaxe geral de um rótulo de atributo $\quad 70$

Figura 6.1 Classes e interface do protótipo. $\quad 77$

$\begin{array}{ll}\text { Figura 6.2 Diagrama de Classes. } & 77\end{array}$

$\begin{array}{ll}\text { Figura 6.3 Diagrama de seqüência de eventos. } & 78\end{array}$

Figura 6.4 Interpretandф uma sentença em linguagem natural 79

Figura 6.5 Transforma a lista de conceitos na mensagem UCL 80

Figura 6.6 Criação de átvore de nós de um documento UCL. 81

Figura 6.7 Transforma à mensagem UCL na lista de conceitos 82

Figura 6.8 Transformar a lista de conceitos numa sentença em linguagem natural $\quad 82$

Figura 6.9 Exemplo : Monkey eats bananas 83

Figura 6.10 Exemplo : Who directed Rendezvous in Paris? 84

Figura 6.11 Arquitetura de um sistema que utiliza a linguagem UCL 85

Tabela 2.1. Performatives teservadas de KQML. 
Tabela 2.2 Comparação/das linguagens ACL.

Tabela 4.1 Comparação do Thought Trasure com outros sistemas 56

Tabela 6.1 Principais etiquetas para a construção de mensagens UCL 


\section{RESUMO}

Uma parte impołtante, da proposta dos agentes de software, é o princípio que esses agentes podem funcionar de fołma mais eficiente quando trabalham em grupos. Para que a cooperação entre agentes tenha sucesso, é requerida comunicação entre eles. Para que essa comunicação seja possivel precisa-se de luma Linguagem de Comunicação entre Agentes (em inglês Agent Communication Language, ou ACL). Dentro de uma ACL, torna-se importante a forma como são comunicadas as mensagens, isto é, se as mensagens expressam adequadamente seu propósito sob um ponto de vista semântico.

O objetivo destę trabalho é a especificação de uma nova ACL, chamada UCL - Universal Communication Language, |que se preocupa com a descrição da estrutura das mensagens, com o modelo semântico e com suporte a protocolos para interação entre agentes (de software ou humanos). Além disso, é importante explorar, no contexto deste trabalho, a utilização do padrão XML (Extensible Markup Language), para atribuir à linguagem UCL meios para uma fácil integração à Internet. Por isso a linguagem UCL foi implementada no padrão XML.

Foi desenvolvido também um protótipo de enconverter-deconverter, que serviu como ferramenta para experinpentação e teste da proposta de linguagem apresentada. Esse protótipo permite a conversão de inglês para UCL e de UCL para inglês, ele usou ferramentas e programas abertos, estando disponíyel para uso de todos sob a GPL (GNU Public License). 


\section{ABSTRACT}

An important part of the software agents' theory is the idea that the agents should work more efficiently in groups. For the cooperation among software agents to be successful, it is required communication between them. To enable this communication an Agent Communication Language (ACL) is required. Messages coded in an ACL should adequately express their meaning from a semantic point of view.

The goal of this work is to specify a new ACL language, called Universal Communication Language (UCL). UCL design is concerned with the description of the messages' structures, the underlining semantic context and the support for protocols for agents interaction (software agents or humans agents). Also, it is important to explore the use of the Extended Markup Language (XML) to make UCL easier to integrate into the Internet. For this reason UCL was implemented using XML.

Also, an enconverter-deconverter software prototype was written to serve as a tool for testing and experimenting with the language specifications. This prototype allows the conversion from English to UCL ard from UCL to English. It was written in Java using open programs and it is available free under the GPL (GNU Public License). 


\section{INTRODUÇÃO}

\subsection{Considerações iniciais.}

À medida que cresce $\mathrm{o}$ interesse pela tecnologia de agentes de software, as ferramentas de software para projeto e construção de sistemas baseados nessa tecnologia começam a aparecer (Sierra et. al. 2000).

Em anos recentes, o interesse em sistemas multi-agentes (MAS) cresceu de forma tal que a abrangência das aplicações baseadas em MAS vai desde bibliotecas digitais até comércio eletrônico. Nessas aplicações, considera-se a existência de cooperação entre seus componentes para poder realizar suas tarefas, em conseqüência todas estas aplicações têm uma coisa em comum: os agentes que operam dentro destes sistemas têm que comunicar (Dignum, 2000).

Neste capitulo, são apresentados as motivações, um breve resumo dos trabalhos relacionados, os objetivos que levaram ao desenvolvimento deste trabalho e a forma como esta monografia está organizada.

\subsection{Motivação}

A tecnologia de agentes desperta o interesse para criar uma nova forma de sistemas de software complexos. (No projeto de agentes, misturam-se muitas das técnicas tradicionais de inteligência artificial ("raciocínio" no nível de conhecimento, flexibilidade) com as experiências obtidas nas áteas de sistemas distribuídos, teorias sobre negociação e teorias de equipe de trabalho, como também das ciências sociais (Dignum, 2000). 
Uma parte importanté da proposta dos agentes de software é que esses agentes (similarmente aos humanos) podem funcionar de forma mais eficiente quando trabalham em grupos, tendo como características importantes a cooperação e a divisão do trabalho.

Para que a cooperaçãb entre agentes tenha sucesso, é requerida comunicação entre eles. Uma coleção de agentes trabalhando juntos em cooperação pode ser vista como uma pequena sociedade, e o funcipnamento de qualquer sociedade coerente precisa de uma linguagem comum e um meio de comunicação. Agentes que trabalham de forma isolada provavelmente serão menos eficazes do que aqueles que são capazes de interagir. (David, 1999).

É tão vasto o camp $\phi$ da comunicação que se toma dificil encaixá-lo numa definição exata. Em getal, a comuniçação é o intercâmbio intencional de informação que se dá mediante a emissão e percepção de sinais que pertencem a um sistema convencional.

O que poderia motivar um agente a realizar atos de comunicação, enquanto ele poderia se concentrar apenas ep realizar ações comuns? Em um caso hipotético, suponha que um grupo de agentes esteja pesquisando em um mundo de domínio específico de conhecimento, um labirinto, e os agentes precisem encontrar um objeto que se encontra em algum lugar do labirinto. Em funçã da tarefa encarregada aos agentes, o grupo se beneficia (em nível coletivo e individual) (quando é capaz de fazer as seguintes ações:

- Trocar informações entre si a respeito da parte do mundo que cada um deles está pesquisando e, assim, poupar trabalho de pesquisa;

- consultar outros agentes sobre determinados aspectos do mundo;

- responder a perguntas de outros agentes;

- aceitar petiçães e propostas;

- compartilhar experiência entre si.

Para estes atos de comunicação e a cooperação entre os agentes serem possíveis precisa-se de uma Linguagem de Comunicação entre Agentes (em inglês Agent Communication Language, ou ACL). Dentro de uma ACL, torna-se importante a forma como são comunicadas estas mensagens, isto é, se as mensagens expressam adequadamente seu propósito sob um ponto 


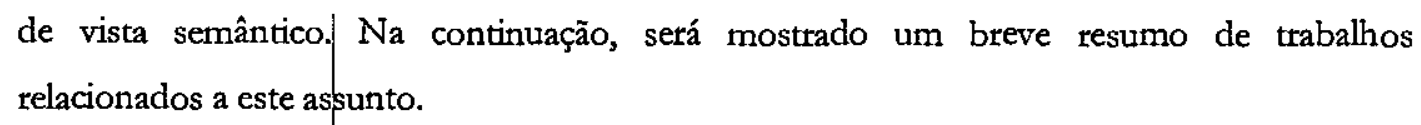

\subsection{Trabalhos relacionados}

Uma primeira tentativa para padronizar uma linguagem de comunicação entre agentes veio do grupo Knowledge Sharing Effort (KSE), que produziu a Knowledge Query and Manipulation Language (KQML). $\varnothing$ objetivo da KQML foi desenvolver fundamentos para interação e interoperabilidade de sistemas de software (ARPA, 1993).

Recentemente, outros esforços estão scndo feitos para padronizar as ACIs. Estas iniciativas foram adotadas pela prganização Foundation for Intelligent Pbysical Agents (FIPA). Em particular, - padrão FIPA para ACL tenta identificar os componentes práticos da comunicação e cooperação inter-agentes (FIPA, 1999).

Estes e outros trabalhos como programação orientada a agentes, comunicação entre agentes móveis, surgiram com propósitos similares aos já mencionados e serão revisados de forma mais clara no capítulo seguinte.

Embora estas iniciatiyas mostrem que alguns trabalhos foram feitos em relação às ACLs, de forma geral, percebe-se a falta de consenso nos fundarnentos para a comunicação entre agentes. Não há um entendimento semântico clato das mensagens a serem transmitidas ou até mesmo os conceitos básicos que deveriam ser usados para definir uma semântica (Dignum, 2000).

Além disso, apesar de a Internet ser um repositório enorme de informação e que muitos sistemas fazem uso dela, percebe-se uma falta de integração das ACLs com as tecnologias da Internet (Grosof \& Labrou, 1999). Em conseqüência, é razoável sugerir que as ACLs deveriam se integrar de uma forma mais fácil a Internet e serem capazes de trabalhar com as ferramentas e a infraestrutura que estão disponíveis nela. Isso motiva a se tentar utilizar a meta linguagem Extensible Marksp Language (XML), projetada para uso na Internet, pata codificação de mensagens em uma ACL como primeiro passo para esta integração. 


\subsection{Objetivos}

O objetivo deste trabalho concentra-se na especificação de urna nova ACL, chamada UCL Universal Communication Language, que se preocupa com a descrição da estrutura das mensagens, com o modelo semântico e com suporte a protocolos para interação entre agentes (de software ou humanos) na Internet.

Na comunicação entre agentes, é imprescindível um entendimento adequado do que vai ser comunicado através da troca de mensagens. Uma boa representação do domínio de conhecimento pode colaborar para um melhor entendimento do contexto em que a troca de mensagens acontece. Como conseqüência, é importante explorar as tentativas de classificar e estruturar conceitos e suas relações dentro de um domínio, focalizando-se no compartilhamento e teúso destes conceitos.

Além disso, é importante explorar, no contexto deste trabalho, a utilização do padrão XML (Extensible Markup Language), para atribuir à linguagem UCL meios para uma fácil integração à Internet. Por isso a linguagem UCL será implementada no padrão XML.

\subsection{Estrutura da dissertação}

Esta dissertação estấ organizada de forma a apresentar o contexto teórico no qual este trabalho está inserido, bem como os resultados obtidos no desenvolvimento do trabalho e as suas contribuições pata a comunidade científica interessada.

No Capítulo 2, é mpstrado o conceito de agentes (de software), destacando-se algumas das definições encontradas na literatura e algumas propriedades dos agentes. Além disto, é mostrada a contextualização deste projeto, relacionado-o a outros trabalhos sobre comunicação entre agentes de software, ressaltando-se os princípios básicos para a comunicação entre agentes.

No Capítulo 3, é apresentado um meio para representar o domínio de conhecimento, especificamente as ontologias e sua importância, como um meio de classificar e estruturar os conceitos e suas relaçóes. Além disso, inclui-se uma metodologia para construir ontologias. 
No Capítulo 4, é apresentada a descrição de várias tecnologias que auxiliaram na especificação da linguagem UCL e a construção de um protótipo que utiliza a linguagem UCL. Entre estas tecnologias, pode-se mencionar a meta-linguagem XML, a linguagem Universal Networking Language (UNL) (Uchida, 1999), e uma outra para representat sẹntenças em linguagem natural na forma de conceitos usando-se a ferramenta Thought Treasure.

No Capítulo 5, é apresentada a especificação da linguagem proposta para a comunicação envolvendo agentes na Internet, que será designada UCL - Universal Communication Language. Incluem-se as consłderações sobre a linguagem e suas características. Além disso, a metodologia que orientou o seu desenvolvimento e, finalmente, uma descrição completa da estrutura das mensagens especificadas nesta linguagem é mostrada.

No Capítulo 6, é aptesentada uma descrição da implementação da linguagem UCL, tomando como base a especificação mostrada no capitulo 5. Apresentam-se também diagramas para explicar os vários processos usados para a criação das mensagens utilizando-se os recursos tecnológicos mostrados no capítulo 3 e 4 .

Finalmente, o Capítulo 7 apresenta as conclusões deste trabalho, considerando as decisões de projeto, contribuições do trabalho e sugestões para pesquisas futuras. 


\section{COMUNICAÇÃO ENTRE AGENTES DE SOFTWARE}

\subsection{Considerações Iniciais}

Assim como é necessária a cooperação entre pessoas na sociedade humana para executar alguma tarefa, existe uma necessidade semelhante num sistema multi-agentes. Esta cooperação se dá pela comunicação (troca de mensagens) entre agentes com o objetivo de executar tarefas deteminadas. Atualmente nesta área, várias pesquisas estão sendo realizadas e linguagens específicas para esse tipo de comunicação estão sendo desenvolvidas.

Este capítulo contém a definição de agentes de software e suas características, os princípios para a comunicação entre esses agentes e algumas linguagens de comunicação que constituem resultado de pesquisas envolvendo a comunicação entre agentes. Será incluída a apresentação de algumas características dessas linguagens, focalizando suas vantagens e desvantagens. Além disso, será apresentada uma comparação entre elas e analisadas as tendências de desenvolvimento.

\subsection{Agentes de Software}

O termo "agente" existe na linguagem dos computadores desde a década de 80 , porém a definição do termo é tão complexa para a comunidade científica quanto a definição do termo "inteligência artificial". Dessa forma, o que tem ocorrido é que cada autor adopta uma definição do termo "ggente" que melhor se adapte ao seu contexto de trabalho.

\subsubsection{Definição de Agente}

Iniciando pela definição encontrada nos dicionários, agente é aquele que opera; é aquele que é encarregado dos hegócios de terceiros. Tais definições consideram duas perspectivas diferentes: a primeira que associa um agente a uma entidade que é capaz de agir; e a segunda 
em que um agente é considerado como um ajudante, ou alguém que atua por intermédio de outra pessoa.

No contexto da ciêthcia da computação, um agente de software pode ser utilizado para facilitar a criação de software capaz de interoperar, ou seja, trocar informações e serviços com outros programas e, dessa forma resolver problemas complexos (Moreira \& Walczowski, 1997). Porém, pode-se observar algumas outras definições feitas por outros pesquisadores da área:

- Agentes de softuare são componentes de software capazes de comunicar e cooperar com seus pares por meio da troca de mensagens, usando uma linguagem de comunicação)(Ketchpel \& Genesereth, 1994).

- Agentes são| sistemas computacionais que habitam algum ambiente complexo dinâmico, percebem e agem de maneira autónoma nesse ambiente e, assim, atingem objetivos ou cumprem tarefas para as quais foram designados (Maes, 1994).

- Agente é um hardware ou (mais usualmente) um sistema computacional baseado em software que tem características como autonomia, capacidade social, reatividade e proatividade (Jennings \& Wooldridge, 1995).

O termo "agente" não tem uma definição consensual, talvez por cobrir diversas áreas de investigação e desenvolvimento. As várias definições de agentes fornecem uma lista de atributos para eles, o que não significa que todos os agentes tenham que, necessariamente, conter todos os attibutos, os quais dependem do tipo de aplicação que está sendo desenvolvida (Gouveia et al., 1998). Segundo (Franklin \& Graesser, 1996), as características encontradas na maiontia dos agentes são:

- Autonomia: um agente será tão mais autônomo, quanto mais controle tiver sobte as suas ações. Um agente pode ser considerado autônomo em relação ao ambiente ou em relação a putros agentes.

- Pró-atividade: um agente pró-ativo toma a iniciativa para atingir os seus objetivos, não se limitando a responder a estímulos do ambiente. 
- Reatividade: um agente tem capacidade de reagir às mudanças que sente no ambiente (estímulos).

- Continuidade Temporal: um agente está continuamente ativo. Nota-se que grande parte do soffuare existente não tem essa característica, já que esses programas executam uma ou mais tarefas e terminam.

- Capacidade Social: se um agente tern capacidade social, então ele pode se comunicar com outros agentes, o que poderá incluir humanos. Dessa comunicação poderá resultar uma cooperação. Para o caso específico da comunicação entre o agente de software e $q$ usuário humano deverá ocorrer uma cooperação na construção do "contrato" sobre o que o agente deverá fazer e não uma simples ordem.

- Capacidade de Adaptação: um agente com capacidade de adaptação é capaz de alterar seu comportamento com base na experiência. Esse tipo de agente é o chamado "agente inteligente", pois possui a capacidade de aprendizagem. A adaptação pode ser relativa ao ambiente ou no sentido de melhorar a sua interação com outros agentes.

- Mobilidade: corresponde à capacidade de o agente se mover dentro do ambiente. Quando se trata de agentes de software, um agente móvel é aquele capaz de se transportar de uma máquina para outra durante a sua execução.

- Flexibilidade: um agente com flexibilidade é aquele que não executa ações prédefinidas em roteiros. Ou seja, possui a capacidade de escolher dinamicamente seqüências de ações em resposta a um estado do ambiente.

Para (Franklin \& Graesser, 1990), autonomia, pró-atividade, reatividade e continuidade temporal são características essenciais em um agente.

\subsection{Princípios para comunicação entre agentes}

$\mathrm{Na}$ busca por uma linguagem de comunicação entre agentes (Agent Communication Language $\mathrm{ACL}$ ), houve várias iniciativas e trabalhos pioneiros dos grupos de pesquisa Knowledge Sharing Effort e da Fundation for Intelligent Pbysical Agents (FIPA) que têm formulado fundamentos 
teóricos para que agentes possam interagir independentemente do ambiente de implementação (Mamadou et al., 2000).

O projeto das linguagens de comunicação para agentes (ACLs) evoluiu em torno de vátios principios, tais como heterogeneidade, cooperação e coordenação, separação, interoperabilidade, ransparência, escalabilidade, estensibilidade, e desempenho. Uma linguagem de comunicação para agentes pode ser importante para um grande número de áreas de aplicação se estes princípios são observados. A generalização de um framework de uma ACL pode ser caracterizada pelos seguintes princípios (Mamadou, 2000):

- O princípio de heterogeneidade: Afirma que o agente deve ser capaz de se comunicar independentemente de seu ambiente de implementação. Nessa comunicação as mensagens trocadas devem refletir uma perspectiva global em lugar de uma perspectiva peivada do agente emissor ou receptor.

- Os princípios de cooperação e coordenação: Afirmam que, para que uma cooperação seja efetiva e tenha o propósito de resolver uma tarefa complexa, é necessária uma linguagem de comunicação significativa. Geralmente, a comunicação entre agentes inclui transportar e trocar informação sobre o conhecimento dos agentes ou de seus ambientes. Neste sentido, uma ACL deve dar aos agentes os meios através dos quais eles possam se coordenar para alcançar seus objetivos.

- O princípio de separação: Afirma que o conteúdo, a estrutura, e o mecanismo de transporte de uma mensagem constituem entidades distintas que devem ser tratadas separadamente.

- O princípio de interoperabilidade: Afirma que uma ACL deve fornecer aos agentes meios para interoperar. A integração de software baseada em agentes foi concebida para permitir que componentes de software heterogêneos, modelados como agentes, possam inter $\phi$ perar usando uma linguagem apropriada.

- O princípio de transparência: Afirma que um sistema multi-agente deve ser protegido das complexidades existentes na especificação de uma ACL. Neste sentido, uma API (Application Ppgramming Interface) adequada a uma ACL libera os agentes dos detalhes específicos e determina as interações num nível mais alto. 
- Os princípios de escalabilidade e estensibilidade: Afirmam que os projetistas de ACLs podem adicionar novos atos comunicativos compativeis com aqueles existentes. Estes novos atos podem implementar novos protocolos de interação. Além disso, o projeto de urna ACL deve considerar escalabilidade em relação ao crescimento do número de agentes em um sistema multi-agente.

- O princípio de desempenho: Afirma que uma implementação de ACL deve usar eficientemente os recursos do sistema (CPU, memória e largura de banda). Os atos primitivos de comunicação fornecidos pela linguagem devem ser compatíveis com a tecnologia de rede usada e exibir capacidades de conexão unicast, multicast, síncrona e assíncrona. Allém disso, uma ACL deve suportar uma troca de mensagens confiável e segura entre dgentes.

\subsection{Especificações de uma linguagem de comunicação para agentes}

A especificação de uma linguagem preocupa-se com a descrição da estrutura da mensagem, seu modelo semântico e os protocolos de interação em que se apóia (Mamadou, 2000):

- O formato da mensagem define os atos de comunicação (communicative acts) primitivos e os parâmetros da mensagem (como sender, receiver, etc.). $O$ conteúdo da mensagem descreve fatos, ações, ou objetos em uma linguagem de conteúdo (KIF, Prolog, etc). Outros parâmetros podem cuidar do significado da mensagem (ontologia) e sua entrega.

- O modelo semântico de uma $\mathrm{ACL}$ estabelece os fundamentos para obter um significado conciso e não ambíguo das mensagens do agente e dos protocolos de interação.

- Os protocolos de interação são conjuntos de padrões bem definidos projetados para facilitar a comunicação entre agentes. Protocolos são opcionais, mas, caso sejam usados, a comunicação entre agentes deve ser consistente com o protocolo escolhido. Os seguintes protocolos de comunicação podem ser usados no projeto de ACLs: 
- Protọcolo de comunicação direta: Este tipo de protocolo é aplicado quando um agente emissor conhece $o$ agente receptor e suas capacidades.

- Protocolo Contract Net. Projetado originalmente por Davies e Smith em (Davis \& Smith, 1983), este protocolo define, em sua forma genérica, padrões de interação entre um agente (the manager) com outros agentes (contractors) para executar alguma tarefa complexa. Os agentes Contractors submetem propostas de tarefas ao agente manager, que as avalia e atribui seguindo algumas condiçōes. Os contractors, que tiveram suas propostas aceitas, são tesponsáveis por executar a tarefa atribuída e enviar de volta o resultado ao manager.

- Protocolo de comunicação mediado: Este protocolo utiliza os serviços de agentes especiais (denominados facilitators) que atuam como brokers entre agentes necessitando de algum serviço e agentes que forneçam esse serviço. A mediação envolve agentes fazendo pedidos de serviço e facilitadores negociando, recrutado e recomendando agentes, que registraram suas identidades e capacidades, para executar esses serviços.

\subsection{A linguagem de Comunicação KQML}

Knowledge Query and Manipulation Language (KQML) é uma linguagem versátil de propósito geral que suporta a comunicação entre vários agentes com um conjunto de primitivas reservadas chamadas performatives. A linguagem KQML adotou o termo performatives para designar as primitivas das mensagens. A definição deste termo segundo (Labrou et. al., 1999) se refere a uma declăração feita pelo usuário emissor e que é executada pelo agente receptor, simplesmente por que o emissor a declara ou afirma.

A KQML, descrita por Tim Finin em (Finin et al., 1993), é o resultado de pesquisas feitas pelo grupo Knowledge Sharing Effort (KSE) (ARPA, 1993), cuja iniciativa teve por objetivo desenvolver fundamentos para interação e interoperabilidade em sistemas de software. Três subgrupos de trabalho com objetivos complementares compõem o KSE:

- O grupo de Interlíngua, que projetou o Knowledge Interchange Format (KIF) como uma linguagem comum para descrever o conteúdo de mensagens. 
- O grupo Shated and Reusable Knowledge Base (SRKB), que se interessa pelo conteúdo de bases de conhecimento compartilhadas.

- O grupo External Interface, que produziu a linguagem $\mathrm{KQML}$ e considerou as interações dos componentes do sistema em tempo de execução.

Em KQML, as mensagens são expressas por meio de performatives e elas definem as operações que um agente pode conduzir. O conteúdo de uma mensagem KQML pode ser descrito em várias linguagens, inclusive $\mathrm{KIF}$, desde que a linguagem escolhida possa expressar os performatives de maneira adequada. A lista completa dos performatives reservados e seus significados estão ilustrados na Tabela 2.1. Nesta tabela $S$ representa o agente que envia uma mensagem de pedido (emissor) e $R$ é o agente que recebe os pedidos de outros agentes (receptor).

Tabela 2.1. Performatives reservadas de KQML.

$\mathrm{S}$ : agente emissor, $\mathrm{R}$ : agente receptor.

\begin{tabular}{|c|c|c|c|}
\hline Categoria & & Nome & Significado \\
\hline \multirow[t]{10}{*}{ Discurso } & \multicolumn{2}{|c|}{ Ask-if } & S quer saber se um conteúdo está na base de conhecimento de $\mathrm{R}$. \\
\hline & \multicolumn{2}{|c|}{ Ask-one, ask-all } & S quer perguntar a um ou a todos o conteúdo de algo. \\
\hline & \multicolumn{2}{|c|}{ strearh-all } & Versão múltipla de ask-all. \\
\hline & Eos & & End-of-stream, marcador de fim de múltipla resposta (stream-all). \\
\hline & \multicolumn{2}{|c|}{ Tell, untell } & $\begin{array}{l}\text { er informar a } \mathrm{R} \text { sobre uma sentença que está ou não na base de } \\
\text { conhecimento. }\end{array}$ \\
\hline & Deny & & $\begin{array}{l}\text { S quer informar a } R \text { que uma sentença não está na base de } \\
\text { conhecimento. }\end{array}$ \\
\hline & \multicolumn{2}{|c|}{ Insert, uninsert } & S solicita que $\mathrm{R}$ adicione um conteúdo na base de conhecimento. \\
\hline & \multicolumn{2}{|c|}{$\begin{array}{l}\text { Delete-one, } \\
\text { Delete-all, undelete }\end{array}$} & $\begin{array}{l}\text { S quer que } \mathrm{R} \text { apague um ou mais sentenças da sua base de } \\
\text { conhecimento. }\end{array}$ \\
\hline & \multicolumn{2}{|c|}{ Achietve, unachieve } & S quer de $\mathrm{R}$ alguma coisa. \\
\hline & \multicolumn{2}{|c|}{$\begin{array}{l}\text { Advettive, } \\
\text { Unadvertive }\end{array}$} & $\begin{array}{l}\text { S informa a } \vec{R} \text { de sua capacidade e disposição para processar } \\
\text { conteúdo. }\end{array}$ \\
\hline
\end{tabular}

\begin{tabular}{|l|l|l|}
\hline \multirow{2}{*}{ Categoria } & \multicolumn{1}{|c|}{ Nome } & \multicolumn{1}{c|}{ Significado } \\
\hline \multirow{4}{*}{$\begin{array}{l}\text { Intervenção e } \\
\text { Mecanismos }\end{array}$} & Subscribe & S quer atualizaçöes regulares sobre pefformatives dn facilitador. \\
\cline { 2 - 3 } & Erroo & S considera as mensagens prévias de R como mal formadas. \\
\cline { 2 - 3 } & Sorry & S entende as mensagens de R, mas não fornece ajuda. \\
\cline { 2 - 3 } & Stanqby & $\begin{array}{l}\text { S quer anunciar a R que está pronto para fornecer respostas a suas } \\
\text { mensagens }\end{array}$ \\
\cline { 2 - 3 } & Ready & S está pronto para responder as mensagens prévias de R \\
\hline & Next & S quer a resposta seguinte de R à mensagem previamente enviada. \\
\hline & Rest & S quer o que falta de R \\
\cline { 2 - 3 } & Discard & $\begin{array}{l}\text { S ignora qualquer resposta restante de uma mensagem multi- } \\
\text { resposta }\end{array}$ \\
\hline
\end{tabular}




\begin{tabular}{|c|c|c|}
\hline Categoria & Nome & Significado \\
\hline \multirow{7}{*}{$\begin{array}{l}\text { Facilitação } \\
\text { e Rede }\end{array}$} & Registter, unregister & S anuncia ao facilitador que quer fazer ou desfazer uma inscrição. \\
\hline & $\begin{array}{c}\text { Forupard } \\
\vdots \\
\end{array}$ & $\begin{array}{l}\text { S quer do facilitador uma transferência da mensagem a outro } \\
\text { agente }\end{array}$ \\
\hline & Broatdcast & $\begin{array}{l}\text { S quer do facilitador o envio de uma mensagem a todos os agentes } \\
\text { conhecidos. }\end{array}$ \\
\hline & Transport-address & S associa seu nnme a um nnvo endereço de transporte. \\
\hline & $\begin{array}{l}\text { Broker-one, } \\
\text { broker-all }\end{array}$ & $\begin{array}{l}\text { S solicita ao facilitadinr pasa encontrar um agente disponivel que } \\
\text { forneça uma ou mais respnstas a uma performative. }\end{array}$ \\
\hline & $\begin{array}{l}\text { Recomended-one, } \\
\text { Recnmended-all } \\
\end{array}$ & $\begin{array}{l}\text { S quer do facilitador recnmendações snbre ns agentes que estão } \\
\text { dispnniveis para executar uma performative. }\end{array}$ \\
\hline & $\begin{array}{l}\text { Recruit-nne, } \\
\text { recruit-all }\end{array}$ & $\begin{array}{l}\text { S quer que facilitador encontre um agente adequadn disponivel } \\
\text { para responder a uma pefformative. }\end{array}$ \\
\hline
\end{tabular}

Para mostrar como são utilizadas as performatives apresentadas na Tabela 2.1, é mostrado a seguir um exernplo de um simples cenário de conversação em $K Q M L$ a respeito de um "call for papers" para uma conferência, no qual $C$ é o agente que preside a conferência, $R$ é o agente receptor e $A$ é um agente relacionado com $R$. Ao presidir a conferência, $C$ faz um broadcast para os agentes intestessados no "call for papers", tais como $R$, que eventualmente transfere a mensagern para quent está relacionado com ele, como $A$ :

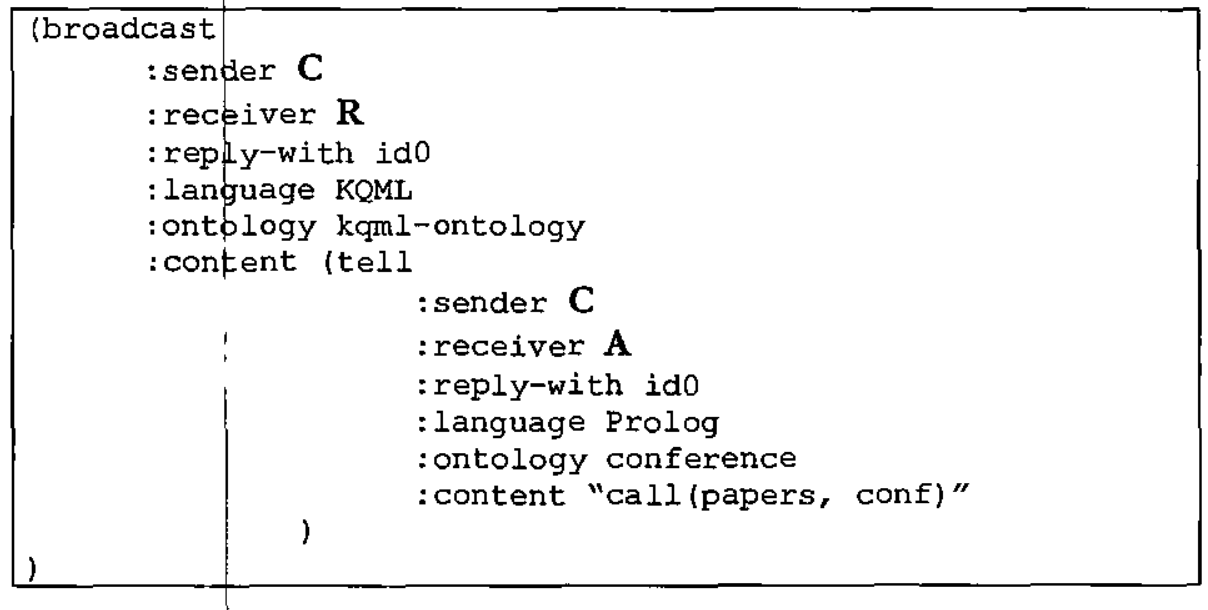

Após o "call for papers" para a conferência, o agente $A$ sugere seu paper para o agente $C$, que preside a conferência 


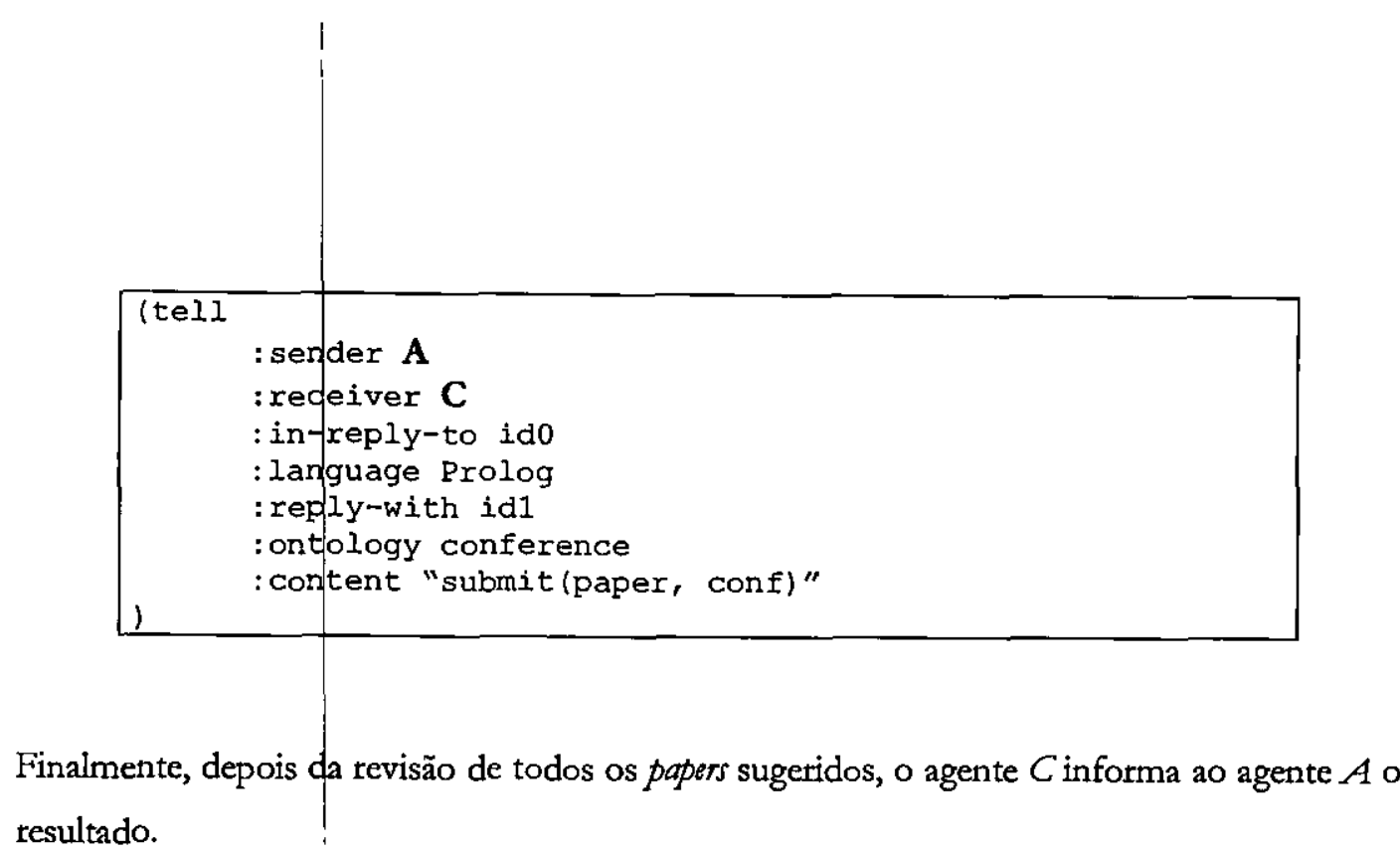

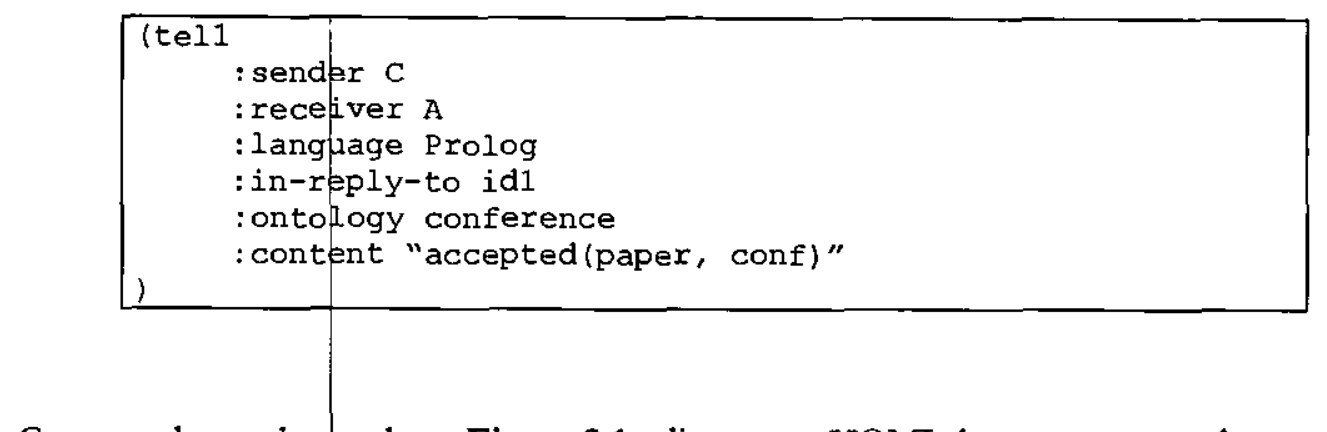

Como pode ser obsezvado na Figura 2.1, a linguagem KQML é composta por três camadas:

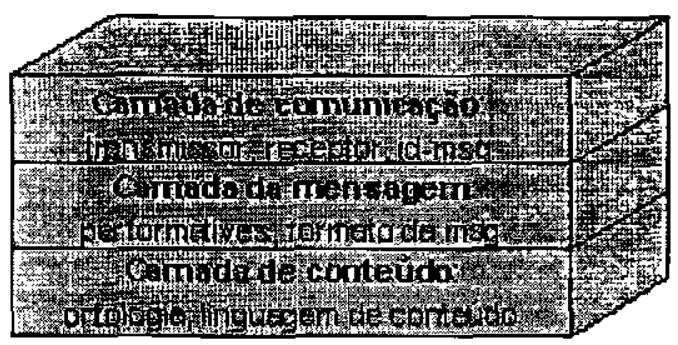

Figura 2.1. Estrutura das três camadas KQML

Camada de conteúdo: Esta camada abriga uma linguagem de conteúdo, tal como KIF ou Prolog. Para que dois ou mais agentes se comuniquem precisam concordar na utilização da mesma linguagem de conteúdo.

Camada de mensagem: esta camada é utilizada para codificar uma mensagem de uma aplicação para outral Esta mensagem pode ser de dois tipos: content message ou declaration message. O primeiro tipo faz uma descrição do conhecimento que está representado na 
camada de conteúdo. O segundo tipo serve para anunciar a presença de um agente no sistema, ou fomecer uma descrição geral da informação que o agente enviará ou receberá.

Camada de comunicação: é através desta camada que os agentes trocam pacotes. Estes pacotes são como um invólucro da mensagem, e especificam alguns atributos da comunicação tais como a especificação do emissor e do receptor.

Em KQML, há principalmente dois tipos de comunicação entre agentes: comunicação direta e mediada. No primeiro tipo, um agente conhece exatamente qual agente pode processar seu pedido. Assim, ele envia seu pedido diretamente a este agente. No segundo tipo, um agente faz pedidos para um agente especial chamado facilitador (facilitator). A função deste é coordenar as interaçळes dos agentes envolvidos em um problema particular, que pode ser resolvido através de:

- Transferência de pedidos aos agentes apropriados.

- Brokering, convocação e recomendação de um agente adequado para outro agente.

- Iniciar a resol|cção distribuída de um problema envolvendo agentes.

Presume-se que todos os agentes interessados informaram suas identidades, interesses e capacidades ao facilitador. Num ambiente de comunicação KQML, um K-router cuida da chegada das mensagens que serão futuramente processadas pela API Router Interface Library (KRIL) do KQML.

O número de aplicações da linguagem $K Q M L$ varia da engenharia de bardware e sistemas de software a sistemas de banco de dados e experimentos na integração tecnológica. Uma das aplicações promissoras é a integração de software baseado em agentes (Agent-Based softrvare Integration - ABSE) mostrado em (Ketchpel \& Genesereth, 1994), em que a integração e interoperação entre componentes de softwate são alcançadas com agentes facilitadores.

\subsubsection{Vantagens e limitações da linguagem KQML.}

A principal vantagem da linguagem $\mathrm{KQML}$ é a sua capacidade para suportar várias arquiteturas diferentes de agentes com seu conjunto estensível de performatives. Como resultado, KQML tornou-se uma linguagem padrão para comunicação entre agentes em diferentes áreas de aplicação. No entanto, a sua primeira versão teve algumas críticas como 
pode ser observado em (Cohen \& Levesque, 1995), que apontam para uma confusão no uso destas performatives. De certa forma, devido a esta fraqueza, vários dialetos de KQML surgiram na indústria e foram usados em diferentes projetos de agentes de software que não podem interoperar. Felizmente, uma nova especificação não oficial (Labrou \& Finin, 1997a) está melhorando a semântica e os conjuntos de performatives.

\subsection{A linguagem AGENT-0}

A linguagem AGENT-0 foi projetada por Torrance (Torrance, 1998), com o propósito de especificar agentes de software. Esta linguagem é baseada nos princípios definidos por Yoav Shoham (Shoham, 1993) que os introduziu como um novo paradigma de programação, chamada programação orientada a agente (Agent Oriented Programming - AOP). Este paradigma, descrito etn (Shoham, 1993), é um framenork computacional cujos conceitos são baseados em inteligência artificial (AI), speech act theory (Cohen \& Levesque, 1990b), e progtamação orientada a objeto. De acordo com Shoham, neste framework um agente é uma entidade cujo estado é formado por componentes "mentais" tais como crenças, capacidades, escolhas e compromissos (Shoham, 1993). A definição de uma linguagem baseada em AOP deve ser formal e concisa, para que ela possa expressar satisfatoriamente os atos comunicativos e "estados mentais" do agente.

Nesta linguagem há somente três primitivas baseadas nos atos de comunicação: inform, request, e unrequest, que podem ser combinados para expressar urna variedade de ações.

\subsubsection{Vantagens e limitações da linguagem AGENT-O}

A idéia de atribuir atitudes mentais aos agentes de software na linguagem AGENT-0 é realmente único e attativo. No entanto, o número pequeno (somente três) de primitivas de atos de comunicação disponíveis, faz com que esta linguagem se torne imprópria para a maioria das aplicaçôes do mundo real. Conforme David Parks em (Parks, 1997), a base teórica da $\mathrm{AOP}$ ainda é uma área pouco desenvolvida porque não está direcionada a assuntos importantes como:

- Descrição formal dos fundamentos da teoria dos estados mentais.

- Segurança em redes heterogêneas. 
Além disso, AGENT-0 precisa de uma linguagem de implementação mais expressiva para transformar-se em un paradigma de programação completo (Parks, 1997).

\subsection{Linguagens de comunicação para Agentes Móveis}

Um agente móvel é um programa que pode migrar de forma autônoma através de uma rede de computadores heterogênea. Em qualquer momento ele pode parar, mover-se juntamente com seu estado e dados para uma nova máquina, e reiniciar a execução no ponto em que parou. Agentes móveis são um novo tipo de abstração na comunicação cliente/servidor. $O$ mecanismo de comunicação mais comum usado por agentes móveis é passar mensagens (pedidos ou consultas). Essa passagem de mensagens pode ser feita por vários métodos, como Remote Procedural Calls (RPC), Remoted Method Invocation (RMI) ou através de Object Request Brokers (ORBs). A tecnologia de agentes móveis tem encontrado muitas aplicações interessantes em sistemas multimídia distribuídos, sistemas de tempo teal, computação móvel, automatização de fábricas e sistemas de missão crítica (Mamadou, 2000).

Ao contrário da proposta sobre os estados mentais, a tecnologia de agentes móveis não faz necessariamente uma suposição a tespeito de estados mentais e nem da estrutura social dos agentes. Aqui, agentes são somente processos que são capazes de se mover de forma autônoma e executar tarefas em lugares remotos. Esta propriedade leva a uma diferença na forma como a comunicação entre agentes é definida, como mostrado nos dois exemplos seguintes.

\subsubsection{O tipo de comunicação no sistema Telescript}

Telescript é um sistema de agentes móveis concebido pela General Magic (White, 1994) para introduzir o paradigma de Remote Programming (RP). A arquitetura do sistema Telescript, ilustrado na Figura 2.2, possibilita que os usuários deleguem tarefas a um agente e que este as executem em locais onde os serviços estão disponíveis. A tecnologia Telescript se apóia nos conceitos de lugar, agente, viagem e reunião.

Os agentes se reúnem em servidores ou clientes (lugares) que oferece serviços para os agentes móveis que estão chegando através da rede. A comunicação entre agentes acontece quando eles se reúnem num|lugar ou por meio de instruções de conexão, quando estão em lugares diferentes. Esta comunicação pode ser implementada por meio de agentes que chamam 
procedimentos um dos outros. Na parte central do sistema Telescript, está o Telescript engine, um interpretador que fornece um ambiente para execução para os agentes.

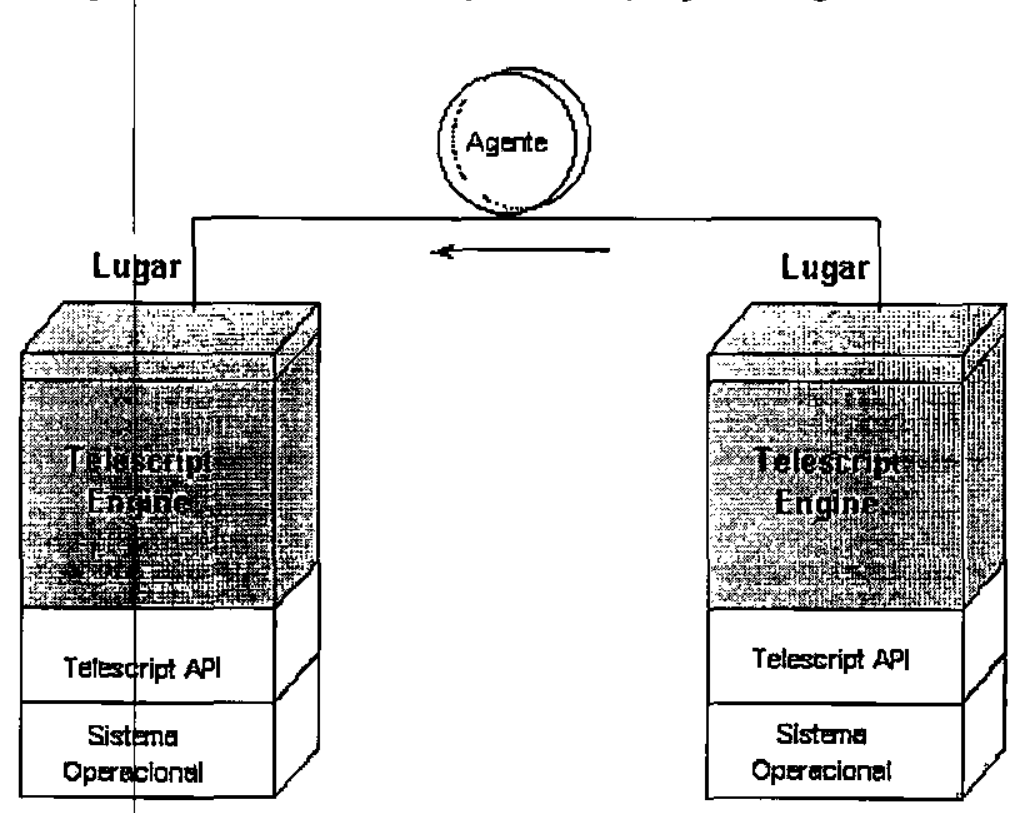

Figura 2.2. Arquitetura do sistema Telescript.

\subsubsection{O tipo de comunicação do sistema Aglets}

Os Aglets (Agile applets) são objetos Java projetados no centro de pesquisa da IBM em Tokyo (Mamadou et al., 2000), que podem migrar, junto com seu código e estado, de forma autônoma dentro de uma rede de computadores e que executar algum trabalho em beneficio do seu proprietário. 0 s agentes se comunicam por meio de message passing (local bost) ou remote message passing (remote host) como mostra a Figura 2.3.

Essas mensagens são objetos (message objects) que são serializados, organizados e enviados, para depois serem armazenados em uma fila de mensagens. Estas mensagens podem pertencer a um dos seguintes tipos:

- Mensagem Now-type, que é síncrona e requer processamento completo pelo receptor;

- Mensagem Future-Type , que é assíncrona;

- Mensagem Oneway-Type, que é também assíncrona, e tratada sempre como última na fila. 
Uma mensagem recebida por um agente é tratada por um método Aglet (Aglet.bandleMessage) antes do seu processamento. Alérn disso, mensagens suportam respostas de confirmação. Os princípios da programação de agentes móveis Java são explicados pelos projetistas desta tecnologia em (Lange \& Mitsuru, 1998).

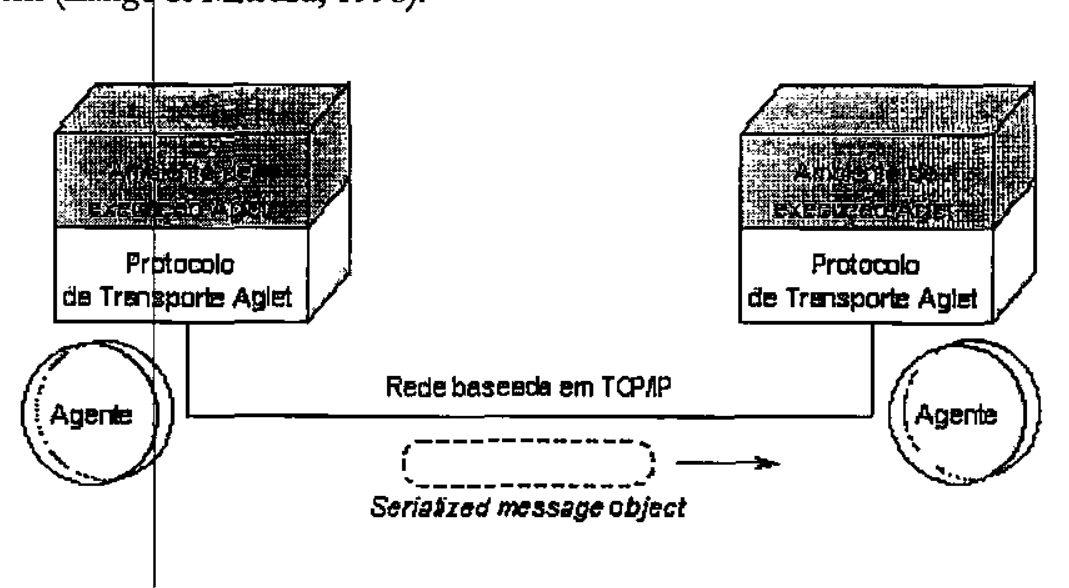

Figura 2.3. A Atquitetura Aglet e modelo de comunicação.

\subsubsection{Vantagens e limitaçōes da comunicação entre Agentes Móveis}

Agentes que são capązes de migrar certamente oferecem uma alternativa atrativa ao estilo de comunicação tipo RPC entre bosts. No entanto, a comunicação interagente apresentada é limitada a pedidos simples. Devido às características dos agentes móveis, não há muito intercâmbio de informação nem conhecimento de domínio. O propósito da comunicação aqui não é buscar a cooperação de outros agentes para resolver uma tarefa, mas, de preferência, fazer uso dos serviços fornecidos no bost destino. Como não existe o conceito de comunidade de agentes, pode-se questionar se os agentes móveis realmente se comunicam.

\subsection{A linguagem FIPA-ACL}

A Foundation for Intellagent Pbysical Agents (FIPA) é uma organização internacional que tern por objetivo desenvolver um conjunto de agentes padronizados e genéricos com a contribuição de todos os participantes envolvidos no desenvolvimento da tecnologia de agentes. Em particular, o padrão FIPA-ACL tenta identificar os componentes da comunicação e cooperação interagente, pela definição de uma linguagem com semântica concisa, formal e com suporte a protocolos de comunicação. De fato, a principal especificação padrão FIPA (FIPA, 1999) é composta por seis sub-especificaçōes: administração de agentes; comunicação 
entre agentes; interação entre agentes; assistência pessoal para viagem, entretenimento e bradcasting audiovisual; e administração.

O centro da especificação FIPA para comunicação entre agentes - que inclui primitivas de comunicação (performatives), um modelo formal, e uma linguagem de conteúdo (Semantic Language SL) - foi extraído da linguagem ARCOL (Sadek et al., 1997) que foi projetada pela France Télecom, enquanto que a KQML inspirou a estrutura de suas mensagens.

O cenário simples nelatado na seção 2.4 , call for papers, para chamada de papers para uma conferência é expresso da seguinte forma na linguagem FIPA-ACL.

Primeir, o agente $\mathrm{C}$ - que preside a conferíncia - envia (cfp) uma chamada de papers a um agente $\mathrm{R}$ interessado.

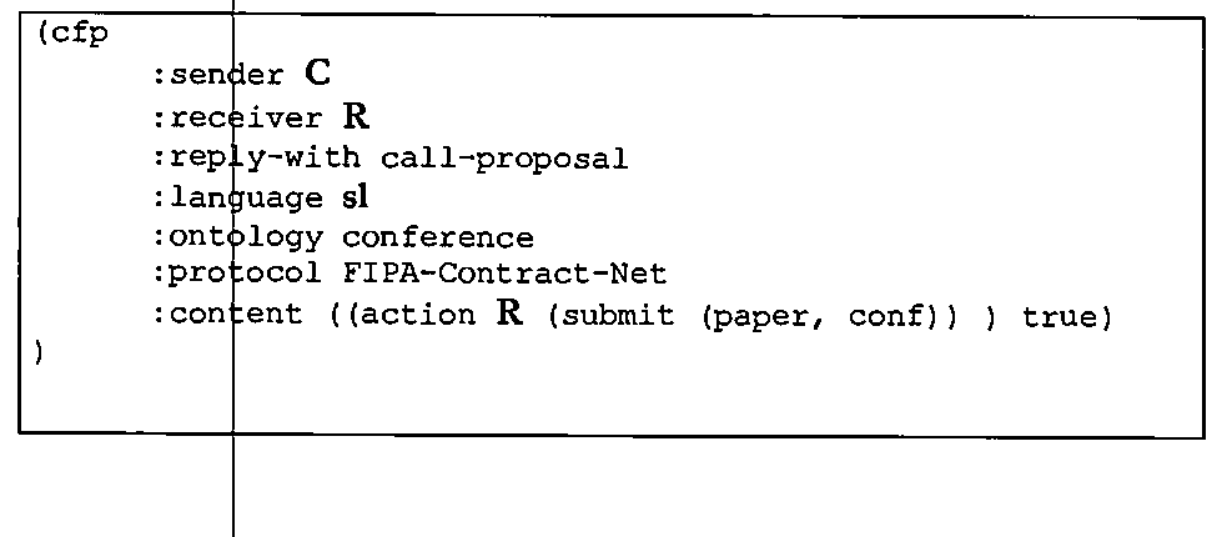

$O$ agente $R$ submete seu paper para revisão com o agente $C$.

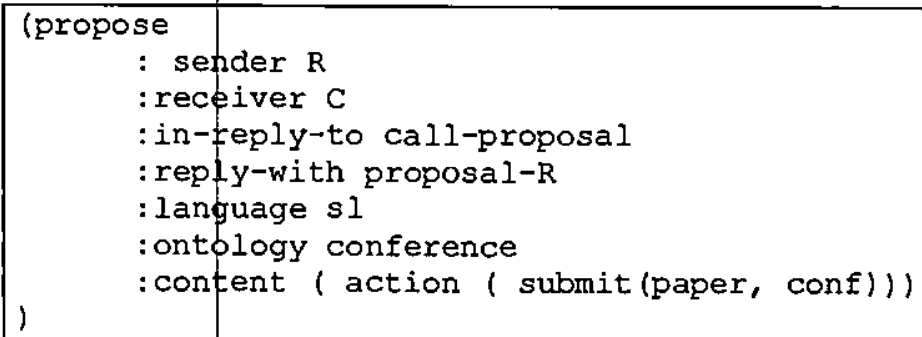




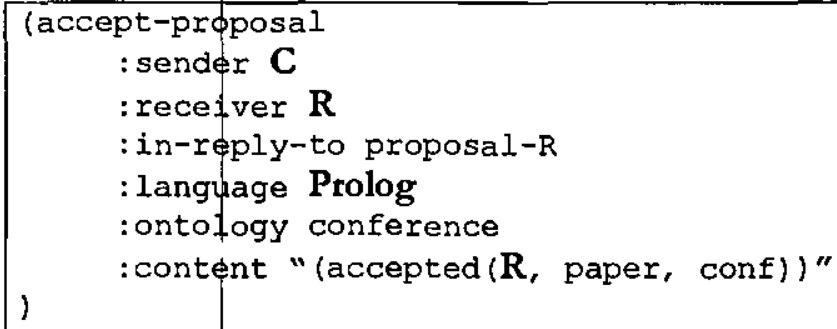

2.8.1. Vantagens a limitações da linguagem FIPA-ACL

A FIPA-ACL é una linguagem de comunicação para agentes que envolve muitas das particularidades da in dústria e da academia. FIPA-ACL se baseia em componentes práticos de comunicação e cooperação interagente com uma semântica formal definida.

Estas características a tornam um ponto de referência. No entanto, ao contrário de outros modelos ACL, a FIPA-ACL sofre da falta de aplicações práticas que poderiam apontar suas desvantagens ou limiţações.

\subsection{Uma proposta para uma $A C L$ com ênfase no ambiente social.}

A comunicação em ssstemas convencionais multi-agentes baseados em atitudes mentais, sofre da falta de uma semântica formal concisa e universalmente aceita. Como resultado, a comunicação entre agentes está limitada a um domínio de ambiente restrito e os agentes heterogêneos não conseguem interagir adequadamente.

Como agentes de software são geralmente definidos em termos de autonomia, interoperabilidade, cooperação e capacidade para coordenar ações em direção a um objetivo comum, as atitudes mentais podem não ajudar a definir uma semântica formal e concisa. Várias soluções atrativas para estas desvantagens foram propostas por Singh (1998), que defende um modelo semântico formal que enfatiza a social agency.

Singh propõe uma teoria que fornece um fundamento conciso para o projeto de sistemas multi-agentes. Nesta teoria, ele mostra que o sucesso de um sistema multi-agente depende de quão bem a ACL suporta a interação entre agentes em um ambiente social. Na Figura 2.4 apresenta-se o espaço de projeto das ACLs segundo (Singh, 1998). A região à esquerda 
representa as ACLs existentes que seguern um modelo de agência mental (mental agency modeð). A região superior direita representa os objetivos a serem alcançados, os quais seguem o modelo de agencia social (social agency model) onde se preferem as seguintes características: uma alta cobertura (incluir todas as categorias significativas de atos de comunicação), contexto flexível, base semântica para o significado, tipo de significado convencional e uma perspectiva pública.

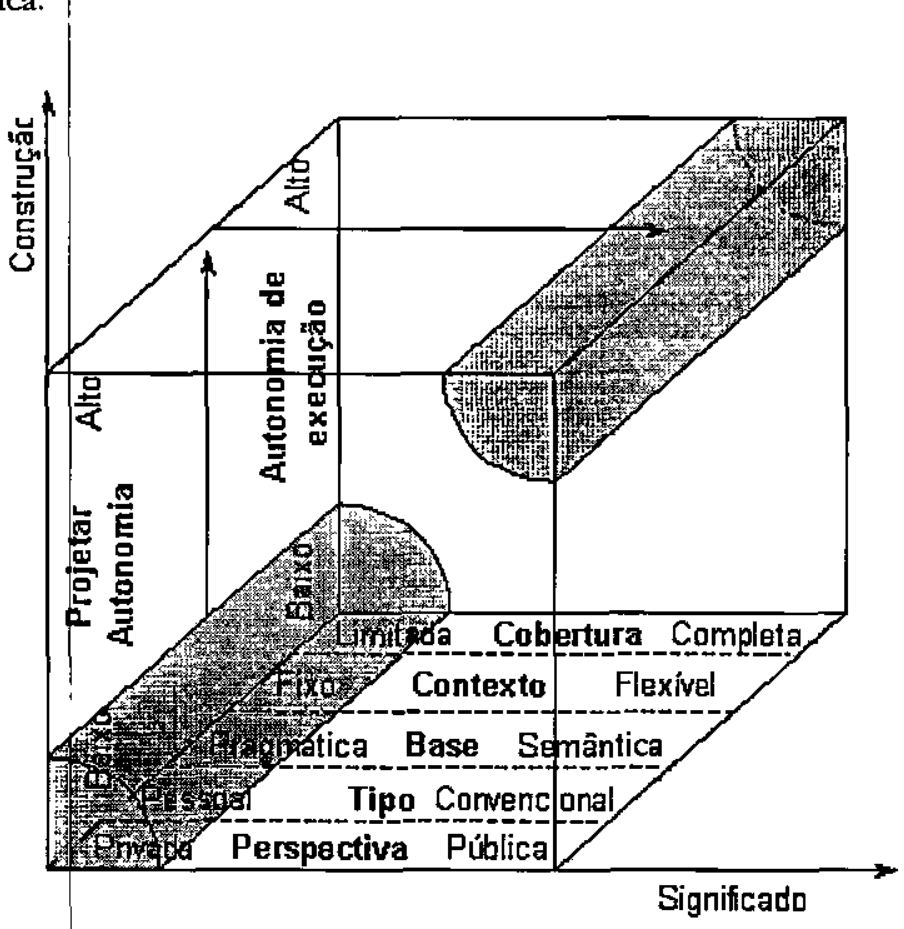

Figura 2.4. Espaço de projeto das linguagens de comunicação de agente(C) 1998 IEEE). Procedência da figura: "Agent Communication Languages: Retbinking the Principles" by Munindar P. Singh in IEEE Computer, volume 31, numer 12, December 1998 , pages $40-47$.

Singh sugere que muitos elementos descritos na Figura 2.4 contribuem para a significância da comunicação entre agentes (Singh, 1998) e elas podem ter as seguintes características:

- Perspectiva deve ser privada (se nos referimos ao transmissor) ou pública (se nos referimos a uma sociedade de agentes).

- Tipo de significado do conteúdo da linguagem é pessoal (estabelecido por um agente) ou convencional (estabelecido por um grupo de agentes). 
- O Contexto deve ser flexível para tomar a comunicação mais significativa.

- Cobertura: Como os atos comunicativos representam o significado, quanto maior sua cobertura (incluindo todas as categorias do Speech Act tbeory) melhor será a interação em um sistema multi-agente (Cohen \& Levesque, 1990b). Além disso, Singh introduz em (Singh, 1999) uma semântica social para ACL baseado em compromissos sociais da lógica temporal.

\subsubsection{Vantagens e limitações da proposta.}

A dimensão social oos sistemas multi-agentes é uma valiosa propriedade para o projeto e administração de grafde parte destes sistemas. O fundamento teórico do modelo social agency estabelecido por Singh propõe o novo campo de integração de software baseado em agentes.

Esta proposta é uma macro teoria que pode ser dificil de implementar em ambientes do mundo real, porque os modelos computacionais impõem restrições que o modelo social agency não poderia definir (Mamadou, 2000).

\subsection{Comparação entre as linguagens $A C L$}

A falta de uma semântica formal e de um formato para as linguagens ACLs aceitos universalmente torna dificil fazer uma comparação em termos dos princípios mostrados na seção 2.1. No entanto, algumas similaridades e diferenças existem entre as ACLs, ilustradas na Tabela 2.2 .

Por exemplo, FIPA-ACL e KQML têm sintaxe similar, formato de mensagem idêntico e compartilham vários parâmetros. Em $\mathrm{KQML}$, as primitivas dos atos comunicativos (Communicative Acts - CAs) apresentam uma dificuldade na descrição das atitudes mentais reais na mensagem do transmissor, enquanto que a FIPA-ACL insere algumas dessas propriedades na expressão do conteúdo da mensagem.

Alguns críticos, tais como Cohen e Levesque, atgumentam (Cohen \& Levesque, 1995) que a semântica de KQML é mal definida, suas performatives (primitivas de comunicação) são ambíguas e não têm uma cobertura completa de todas as interações na comunicação entre agentes. 
Por outto lado, os projetistas da KQML melhoratam sua semântica e forneceram uma fundamentação melhor para muitas aplicações que usam esta linguagem. Embora a linguagem FIPA-ACL esteja causando muito interesse, Yannis Labrou e Tim Finin declararam (Labrou et. al., 1999 ): "Quando surgiu o interesse pela integração dos sistemas multi-agentes por intermédio da comunicação, a linguagem KQML teve um papel pioneiro na definição do que seria uma linguagem de comunicação entre agentes, e de quais características seriam necessárias".

Tab ela 2.2. Comparação das linguagens ACL (Mamadou, 2000).

\begin{tabular}{|c|c|c|c|}
\hline $\begin{array}{c}\text { Elementos ACI } \\
\text { Linguagens ACL }\end{array}$ & $\begin{array}{l}\text { Formato da } \\
\text { mensagem }\end{array}$ & $\begin{array}{l}\text { Conteúdo Sintatico e } \\
\text { Linguagem }\end{array}$ & Conteúdo semântico \\
\hline KQML & $\begin{array}{l}\text { Estrutura em } \\
\text { camadas; separação } \\
\text { entre conteúdo, } \\
\text { mensagem e } \\
\text { comunicação. }\end{array}$ & $\begin{array}{c}\text { Knowledge Interchange } \\
\text { Format (KIF) } \\
\text { Linguagem de } \\
\text { conteúdo não } \\
\text { predefinida } \\
\end{array}$ & Sernântica informal \\
\hline Agent-0 & $\begin{array}{l}\text { Atitudes mentais e } \\
\text { regras de } \\
\text { compromisso; lógica } \\
\text { como base. }\end{array}$ & $\begin{array}{l}\text { Linguagem não } \\
\text { definida }\end{array}$ & Sem semântica \\
\hline Agentes móveis & Message object & $\begin{array}{c}\text { Linguagem não } \\
\text { definida }\end{array}$ & Sem semântica \\
\hline FIPA & $\begin{array}{l}\text { Estrutura em } \\
\text { camadas; Separação } \\
\text { entre conteúdo, } \\
\text { mensagem, e } \\
\text { comunicação. }\end{array}$ & Linguagem SI. & $\begin{array}{l}\text { Semântica formal } \\
\text { baseada em lógica }\end{array}$ \\
\hline $\begin{array}{l}\text { Proposta } \\
\text { Social Agengy }\end{array}$ & $\begin{array}{l}\text { Estrutura social; } \\
\text { agência social ou } \\
\text { comunidade social. }\end{array}$ & $\begin{array}{l}\text { Linguagem não } \\
\text { predefinida }\end{array}$ & $\begin{array}{l}\text { Semântica formal } \\
\text { com perspectiva } \\
\text { pública e crenças } \\
\text { comuns }\end{array}$ \\
\hline
\end{tabular}

Por outro lado, a proposta teórica baseada na dimensão social da interação entre agentes, a Social Agency de Singh (1998), parece complementar as linguagens anteriores.

Em engenharia de software, agentes móveis têm necessidades diferentes a tespeito da comunicação em sistemas multi-agentes. Em sistemas baseados em agentes móveis, a comunicação está intimamente relacionada ao protocolo de transporte, e principalmente, a 
forma dos pedidos de informação. Nenhuma suposição é feita a respeito dos estados mentais no agente móvel.

Para que as linguagens de comunicação entre agentes sejam de importância tanto na indústria como na área acadêmica, os seguintes assuntos teóricos e práticos devem ser resolvidos (Mamadou, 2000):

- Consenso sobre a semântica parece ser o problema mais importante enfrentado pela comunidade de pesquisadores.

- Compartilhamento de ontologias e o conteúdo da linguagem são uma condição prévia para compartilhar conhecimento, porque a habilidade para trocar mensagens não pressupõe o entendimento sobre o conteúdo das mensagens.

- Suporte paraja verdadeira heterogeneidade: agentes de diferentes ambientes ainda não se comunican.

- O gerenciamento da conversação em sistemas multi-agentes deve incluir regras, semântica e protocolos de interação apropriados.

- Testes de conformidade são essenciais para que as ACLs sejam consideradas em concordância com algum padrão. Estes testes assegurarão que diferentes implementaçpes de ACLs permitam aos agentes se comunicarem.

\subsection{Considerações Finais}

A pesquisa nas linguagens de comunicação para agentes (ACLs) está tendo um maior destaque devido às iniciativas dos grupos de pesquisa nesta átea, como o Knowledge Sharing Effort (KSE) e a Foundation for Intelligence Physical Agent (FIPA). Sistemas multi-agentes e suas ACLs relacionadas são áreas de pesquisa que estão florescendo e novas perspectivas, como a interação social entre agentes, vão trazer ainda mais mudanças nessas áreas.

Neste capítulo foi apresentada uma visão global sobre as linguagens de comunicação entre agentes (ACI) que фstão surgindo e esforços de padronização que estão acontecendo nesta 
área. Além disso, foram apresentadas similaridades e diferenças entre estas linguagens e uma introdução sobre alguns assuntos atuais no projeto de uma ACL.

Neste contexto podem-se notar várias preocupações no momento de projetar uma linguagem de comunicação para agentes de software. Este trabalho focará especial atenção aos seguintes assuntos:

- Um consenso na semântica, que é um problema importante para o entendimento da mensagem a ser transmitida, com um significado conciso e não ambiguo.

- Compartilhamento do conhecimento sobre um assunto entre os agentes, e como prérequisito para isto, uso de conceitos para representar senso comum (ontologia). A preocupação estará também em como é representado o conteúdo da linguagem, porque a habilidade para trocar mensagens não assume o entendimento do conteúdo da mensageṃ. No capitulo seguinte será mostrada mais informação sobre este assunto.

Neste ponto, é importante ressaltar que este trabalho leva em consideração os assuntos acima para projetar uma linguagem de comunicação para agentes de software. 


\section{ONTOLOGIAS PARA AGENTES}

\subsection{Considerações iniciais}

$\mathrm{Na}$ comunicação entre agentes de software é imprescindível um entendimento adequado na troca de mensagens. É aí que uma representação do domínio de conhecimento pode colaborar para um melhor entendimento do contexto e, dessa maneira, coordenar as prováveis soluções de um determinado problema.

Este capítulo trata sobre ontologias, que são uma tentativa de classificar e estruturar conceitos e suas reląõos, focalizando-se aqui o compartilhamento e reúso destas estruturas, assim como critérios para projetá-las. Além disso, esse capítulo apresenta também a importância do uso desses conceitos, uma metodologia genérica para construir ontologias e as diferentes ferramentas existentes para o apoio a construção destas ontologias.

\subsection{Definição e Aplicação de Ontologias}

Pessoas, organizaçõos e sistemas de software devem se comunicar. Porém, devido às necessidades e aos contextos diferentes, pode se notar vários pontos de vista e suposições relacionados a um mesmo assunto. A existência de conjuntos de palavras específicas para cada contexto ou assunto de uma área cria discrepâncias, justaposições e/ou conceitos mal compreendidos, em estruturas e métodos. Como conseqüência, surge a falta de um entendimento comum. Isto conduz a (Ushold \& Gruninger, 1990):

1. Uma comunicação pobre, dentro e entre estas pessoas e/ou organizações.

2. Dificuldades na identificação de requisitos e deste modo na definição da especificação do sistema.

3. Restringem a interoperabilidade; 
4. Restringem o potencial para reutilizar e compartilhar informação.

O segundo ponto refere-se ao contexto de construção de sistemas de tecnologia de informação (TI). O terceiro e quarto ponto se referem a discrepâncias no modelamento dos métodos, paradigmas, linguagens e ferramentas de software.

Um caminho para resolver estes problemas é reduzir ou eliminar as confusões conceituais e terminológicas e conseguir uma compreensão comum. Esta compreensão pode funcionar como um frameworke unificador para os diferentes pontos de vista e serve de base para (Ushold \& Gruninget, 1996):

- Comunicaçăa entre pessoas com diferentes necessidades e pontos de vista que surgem em seus diferentes contextos.

- Inter-Operabilidade entre sistemas que interagem com outros sistemas que usam diferentes métodos de modelamento, paradigmas, linguagens e ferramentas de software.

- Benefícios na Engenharia de Sistemas: em particular,

- Reutilização: A compreensão compartilhada é a base para a especificação formal de entidades importantes, atributos, processos e suas inter-relações no domínio de interesse. Esta representação formal pode ser a alavanca para reutilização de componentes compartilhados em um sistema de software.

- Confabilidade: Uma representação formal também torna possível uma automatização na verificação de resultados em um software confiável.

- Espeçificação: a compreensão compartilhada pode ajudar ao processo de identifíicação de requisitos e definição de uma especificação para um sistema de tecnologia de informação. Isto é especialmente vantajoso quando os requisitos envolvem diferentes grupos usando diferentes terminologias no mesmo domínio, ou múltiplos domínios. 
Alguns exemplos práticos, na unificação de áreas de pesquisa, na fabricação de semicondutores, e pa missão de operações de astronaves, são descritos em (Ushold \& Gruninger, 1996) como uma amostra das utilidades das ontologias.

\subsubsection{Definição de Ontologia}

'Ontologia' é um termo usado para se referir ao senso comum de algum domínio de interesse. A ontologia pode ser usada como um framenork unificador para resolver os problemas apresentados anteriormente (Ushold \& Gruninger, 1996).

Uma ontologia necessariamente vincula ou inclui algum tipo de "visão geral" referente a um domínio determinado. Esta "visão geral" é freqüentemente concebida como um conjunto conceitos (por exemplo: entidades, atributos, processos), suas definições e suas inter-relações. Isto é chamada uma conceitualização (conceptualisation).

Uma conceitualização pode estar concretamente implementada, como por exemplo, em um componente de software, ou pode ser abstrata, definida em linguagem natural de uma forma não formal. A palavra 'Ontologia' é algumas vezes usada para chamar isto de uma conceitualização implícita. Porém, o uso mais padronizado e que será adotado neste documento é que ontologia é uma idéia explícita, ou uma representação (de alguma parte) de uma conceitualização

\subsubsection{Caracteristicas de uma ontologia}

Uma ontologia explicita pode tomar uma variedade de formas, mas necessariamente ela incluirá um vocabulátio de termos e alguma especificação dos seus significados (por exemplo: definições).

A maneira como estẹs vocabulários são criados e especificados tem graus de formalidade que variam consideravelmente. Esta variação pode ser mostrada nos seguintes quatro pontos de vista: (Ushold \& Gruhinger, 1996).

- Altamente informal: expresso livremente em linguagem natural.

- Semi-informal: expresso em uma forma restrita e estruturada em linguagem natural. Maior clareza pela tedução de ambigüidade (Fraser et. al., 1995).

- Semiformal: expressa em uma linguagem artificial definida formalmente. 
- Rigorosamente formal: termos meticulosamente definidos com uma semântica formal, teoremas e provas de tais propriedades como completitude e boa qualidade.

Neste ponto é importante ressaltar uma citação que têm como procedência a lista eletrônica SRKB (Shared Re-usable Knowledge Bases), e que resume sutilmente o que é uma ontologia e as várias formas e contextos em que uma surge: (Ushold \& Gruninger, 1996).

"Ontologias são conncordâncias sobre senso comum. Conceitualizações compartilhadas incluem: a) um framezwork conceitual para modelar conhecimentos sobre um domínio; b) protocolos de contéúdo específicos para comunicação entre agentes; c) e concordâncias sobre a representação de teotias de um domínio em particular. No contexto do compartilhamento de conhecimento, ontologias são especificações na forma de definições de um vocabulátio representativo. Um simples caso seria um tipo de hierarquia, especificando as classes e suas relações. Um banco de dados telacional também serve como ontologia através das especificações das relações que podem existir nas tabelas de dados compartilhadas e nas tegras de integridade que oferecem suporte".

Até este ponto, o enfoque foi sobre a identificação de alguns problemas reais e de propostas para resolvê-los. Tratou-se destes problemas de uma forma não controversa, refletindo-se sobre o termo 'ontologia' e como este é usado na comunidade de pesquisa. Infelizmente uma preocupação real é que não existe um consenso no significado do termo ontologia. Uma arıálise sobre esta situação pode ser vista em (Guarino \& Giaretta, 1995).

Parte da confusão é devido ao fato que idéias e assuntos são orientados a vários contextos e áreas, freqüentemente usando diferentes terminologias, tais como: representação e aquisição de conhecimento, ótologias para entendimento da linguagem natural, modelamento de domínios na engenharia de software e empreendimentos de integração.

\subsection{Usos de Ontologias}

A literatura é atualmente rica sobre descrições de ontologias e seus propósitos pretendidos. Em um alto nível, a maioria parece ter pretensões para que, de algum modo, se faça sua reutilização. Alguns destes propósitos estão implícitos dentro das várias interpretações da palavra 'ontologia' que são encontradas na literatura, como por exemplo (Guarino \& 
Giaretta, 1995): um| vocabulátio pata um processo de tradução (Gruber, 1993) ou uma especificação meta-leveldde teoria lógica (Schreiber et. al, 1995; Wielinga et. al, 1994).

Algumas definições sobre ontologias referem-se aos meios para estruturar uma base de conhecimento; outas concebem ontologias como sendo parte de uma base de conhecimento; e algumas se referem a ontologias como uma aplicação específica no domínio das interlinguas (Fuchs \& Wheadon, 1995; Jones et. al, 1995).

Outra importante mptivação pata o uso de ontologias é para integrar modelos de diferentes domínios de conhecimento em framenorks coetentes. Ontologias estão também sendo usadas em processos da re-engenharia (onde se precisa de um modelo integrado da empresa, seus processos, sua organização, objetivos, e seus clientes) e em arquiteturas de multi-agentes distribuídos (onde diferentes agentes se comunicam e solucionam problemas).

Neste ponto, pode-se subdividir os espaços de uso das ontologias dentro das seguintes categorias:

- Comunicação,

- Interoperabilidade,

- Engenharia de Sistemas: especificação, confiabilidade e re-utilização.

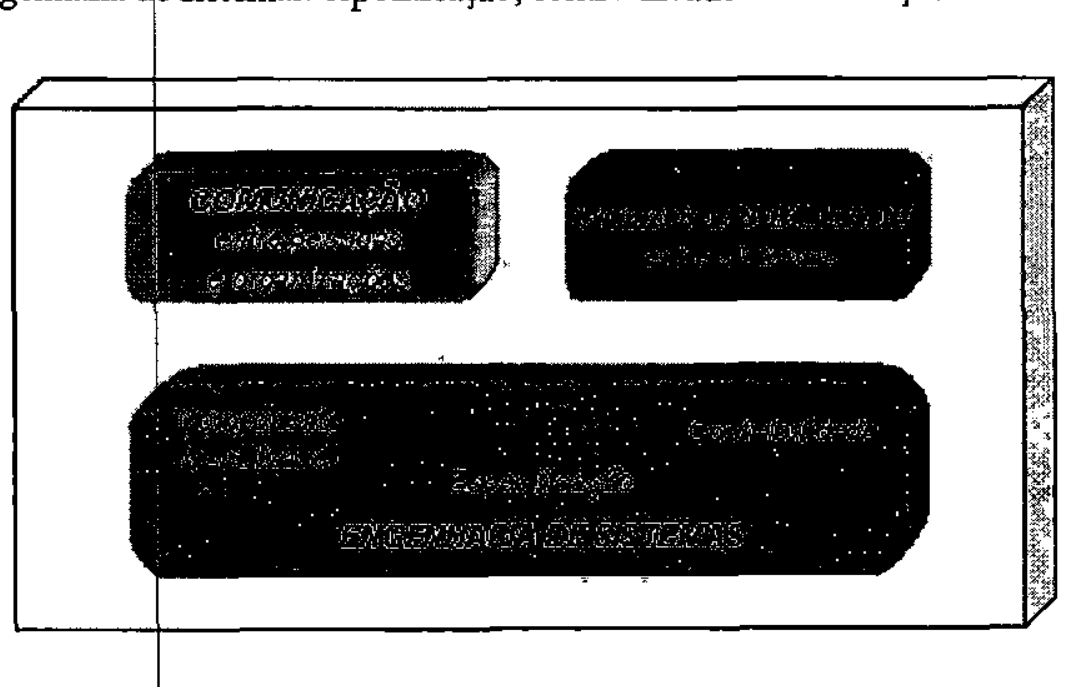

Figura 3.1 Usos de ontologias. 


\subsubsection{Comunicação}

Ontologias reduzem confusões conceituais e terminológicas fornecendo um framework unificador dentro da otganização. Desta forma, ontologias favorecem o entendimento compartilhado e a çomunicação entre pessoas de contextos diferentes com necessidades e pontos de vista particulares. Nos parágrafos seguintes são considerados em detalhe vátios aspectos sobre o usq de ontologias para facilitar a comunicação entre pessoas dentro de uma organização (Ushold \& Gruninger, 1996):

a) Modelos normativos: dentro de qualquer sistema de software amplo e integrado, diferentes pessoas devem ter uma compreensão compartilhada sobre o sistema e seus objetivos. Usando ontologias, pode-se construir um modelo normativo do sistema. Este cria uma semântica para o sistema e um modelo extensível que posteriormente pode ser refinado.

b) Rede de relações: uma ontologia pode ser usada para criar uma rede de relações com o objetivo de manter um registro de dados que estejam sendo relacionados e para permitir a sua exploração pela havegação através desta rede. Considerando-se que pessoas podem ter diferentes perspectivas sobre um mesmo assunto, é necessário unificar essas perspectivas para forma um senso comum. Isto se torna particularmente importante em aplicações que exigem o uso de várias ontologias em diferentes domínios. É neste contexto que as ontologias servem para fazer com que todas estas perspectivas sejam explicitadas, identificando as conexões lógicas entre elas.

De forma geral, pretende-se que as ontologias ajudem no entendimento do impacto de possíveis mudanças num sistema. Por exemplo, pode-se usar uma ontologia para dar suporte a modelagem da descrição de uma organização permitindo capturar uma visão desta para possíveis modificaçōes. Desta forma pode-se dar tesposta às questões da modelagem organizacional, e saber quais cenários variam nas diferentes partes da organização durante uma operação de re-engenharia.

c) Consistência e nẵo-ambigüidade: Um dos papéis mais importantes que uma ontologia representa num sistema é fornecer definições sem ambigüidade para termos usados na definição de suas partes (subsistemas) e na sua interface com o usuátio. Qualquer subsistema deve ser capaz de manter a consistência com os outros subsistemas e suas ontologias. A ontologia usada pela interface tem de ser compatível com a ontologia entendida pelo usuário. 
d) Integrando diferentes perspectivas de usuários: a integração de diferentes perspectivas através da compreensão do domínio de conhecimento compartilhado torna-se vital em um sistema onde vários agentes se comunicam. Existe o desafio de integrar diferentes perspectivas enquanto se identificam diferenças entre elas. Por exemplo, pessoas em diferentes posições em uma organização terão diferentes perspectivas sobre $\circ$ que faz a organização, que objetivos alcançar, e como este objetivos devem ser alcançados. Uma ontologia estabelece os fundamentos para o desenvolvimento de padrões dentro de uma organização. Quando adotamos uma ontologia que possa ser compartilhada, todos os participantes usam upna terminologia padronizada em função dos objetivos e das relações da sua organização.

\subsubsection{Inter-Operabilidade}

A principal preocupação no uso de ontologias em domínios como o modelamento de organizações e arquiteturas multi-agentes é a criação de um ambiente integrador para diferentes ferramentas de software. Muitas dessas ferramentas usam ontologias para lidar com problemas de interoperabilidade (Ushold \& Gruninger, 1996). Elas lidam com diferentes usuários que trocam dados ou que utilizam diferentes ferramentas de software.

\subsubsection{O uso de ontologias como InterLingua}

Qualquer ambiente de tecnologia de informação para a re-engenharia de processos de negócios ou para sistemas multi-agentes deve usar uma descrição integrada do seu modelo organizacional para assim poder especificar suas atividades, recursos, objetivos, produtos, e serviços. Esta descrição serve como um repositório comum e acessível para várias ferramentas de software do ambiente. Ela também pode servir para integrar repositórios de dados existentes, seja pela padronização dos termos usados nestes repositórios, ou pelo uso de tradutores que permitam a interoperabilidade entre eles e sua comunicação com os usuários.

Para facilitar essa interoperabilidade, ontologias devem ser usadas para suportar a tradução entre diferentes linguagens e representações. Uma possibilidade seria projetar um único tradutor para cada par de línguas que se quer fazer comunicar; porém, isto exigiria $O\left(n^{2}\right)$ traduções para $n$ linguagens diferentes, como é mostrado na Figura 3.1a.

Usando uma ontologia como interlíngua para suportar a tradução, pode-se reduzir o número de traduções a $O(n)$ para $n$ linguagens diferentes (Ushold \& Gruninger, 1996), já que isto iria 
requer somente tradưções para uma ontologia nativa, como mostrado na Figura 3.1b (Lee et. al., 1995).

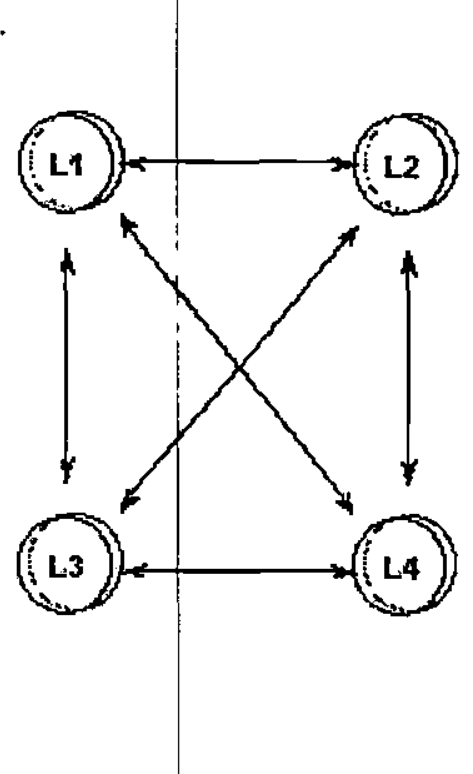

(a)

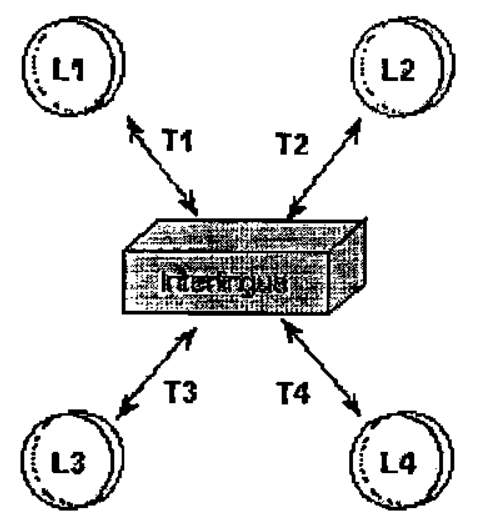

(b)

Figura 3.2 : Ontologia como Interlingua

Pode-se obserpar a tradufäo desde uma linguagem $\mathrm{Li}$ a $\mathrm{L}$ j e viceversa, somente um tradutor é exigido

entre $L_{i}$ a a interlingwa o outro entre a interlingua e Lj. Deste modo, envolvendo $n$ linguagens,

tomente säo requeridas $O(n)$ tradupöes, em comparafão com as $O\left(n^{2}\right)$ do outro método.

\subsubsection{Importancia da Inter-Operabilidade}

Deve-se considerar a natureza das relações entre os usuários que compartilham as ferramentas e os dados, pois ela é vital para que as ontologias e ferramentas que são usadas dentro da mesma ofganização sejam compartilháveis e re-utilizáveis (Guarino \& Giaretta, 1995):

a) Inter-operabilidade interna: Esta característica exige que todos os subsistemas necessitem interoperar desta forma exista um controle direto da unidade organizacional.

b) Inter-operabilidade externa: Esta característica tem-se quando uma unidade organizacional está querendo se comunicar com outros sistemas, procedentes do ambiente externo. 
c) Ontologias intégradas entre os domínios: Outra diferença para interoperabilidade surge do assunto da integração de ontologias a partir de diferentes domínios para suportar tarefas. Por exemplo, uma ontologia para suportar sistemas workflow manogement, necessitariam de ontologias para os processos, recursos, produtos, serviços e a organização. Então, as diversas ferramentas workflow iriam usar este conjunto de ontologias integradas.

d) Ontologias que integram as ferramentas de software: De outro lado, pode-se necessitar diferentes ontologias no mesmo domínio devido à natureza do sistema. Por exemplo, diferentes ferramentas podem querer usar diferentes ontologias relacionadas a processos; para alcançar a interoperabilidade, precisa-se ter uma ontologia comum que ambas ferramentas possam usar. Este é o desafio mais dificultoso a enfrentar no uso de ontologias, visto que usualmente não é possivel impor requisitos de integração sobre as ferramentas.

A Figura 3.2 apresenta o uso de ontologias como uma interlíngua para integrar diferentes ferramentas de software. O termo procedimento é usado em uma ferramenta que é traduzido em outro termo, MÉTODO é usado por outras ferramentas por meio da ontologia, os termos são considerados os mesmos e dentro do conceito processo.

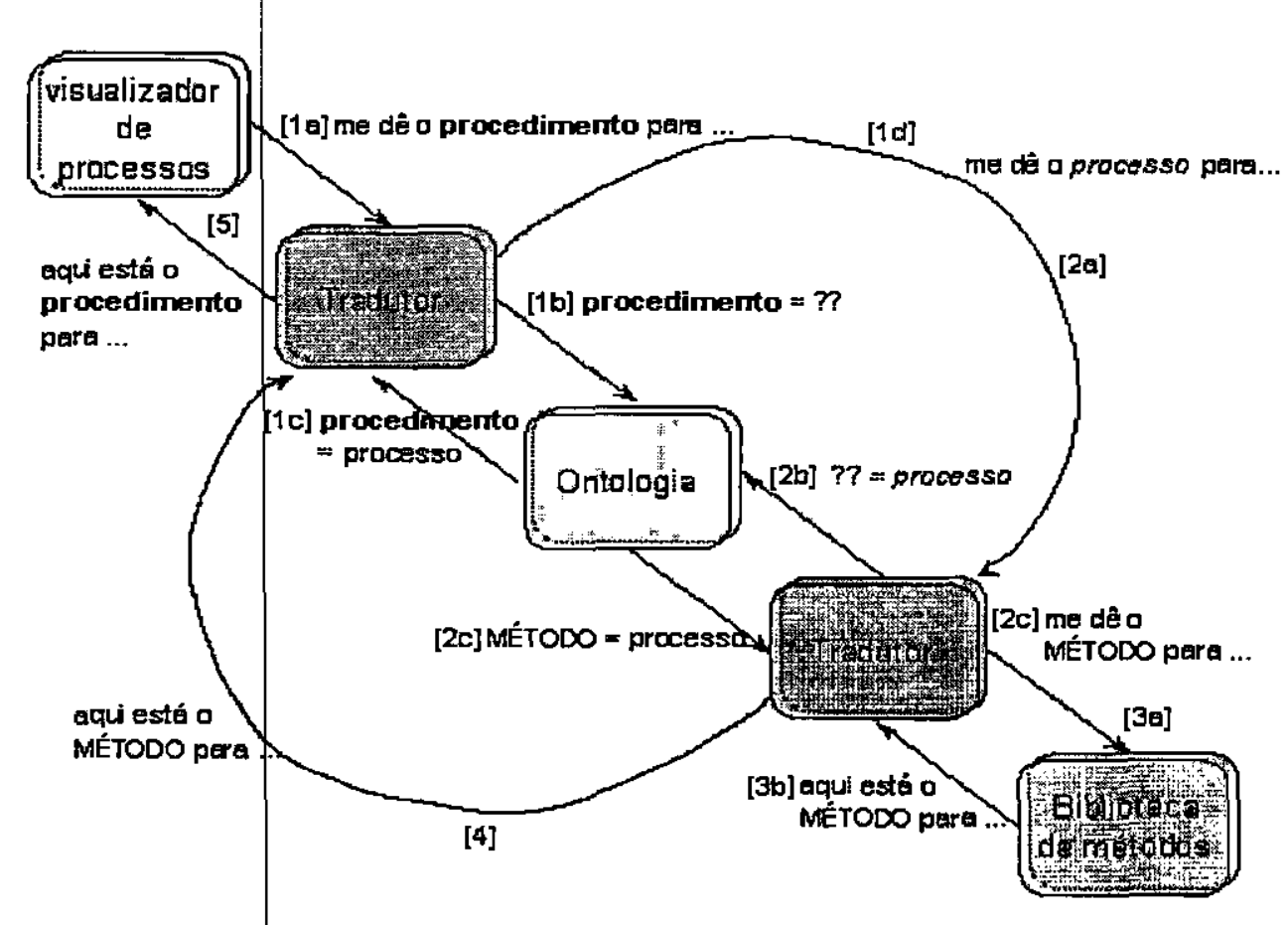

Figura 3.3 Exemplo de uso de ontologia como interlíngua. 


\subsection{Uma metodologia para construir ontologias}

Não existem metodplogias padrão para construir ontologias; nem foi possível encontrar muita informação pyblicada sobre este assunto. Em uma tentativa para começar a preencher esta brecha, uma proposta de metodologia para o desenvolvimento de ontologias foi apresentada por Uschold \& Gruninger (1996), seus principais passos são:

- Identificar o propósito e o âmbito da ontologia;

- Construir a ohtologia;

- Escolher a ontologia,

- Codificar a ontologia,

- Integrar ontologias existentes;

- Avaliar;

- Documentar.

Na continuação, define-se brevemente cada passo e indica-se que tipo de trabalho pode ser feito e que poderia ser usado para desenvolver uma ontologia.

\subsubsection{Identificar o propósito e o âmbito da ontologia}

Esta etapa é importante para deixar claro o porquê da ontologia estar sendo construída e como se pretende usá-la. Na seção anterior, mostrou-se como uma ontologia pode ser utilizada; isto pode ser um ponto de início na identificação dos propósitos da ontologia a ser construída. Também pode ser útil para identificar e representar o alcance pretendido para a ontologia.

\subsubsection{Construindo a ontologia}

A identificação dos propósitos e do âmbito da ontologia, pelo menos em termos gerais, serve para fornecer um objjetivo razoável para construção desta. Três aspectos são considerados nesta etapa: a captura, codificação, e integração de ontologias existentes.

\subsubsection{Escolha}

Entendesse por escolha ontológica:

1. Identificação de conceitos e relações principais envolvidos no domínio de interesse;

2. Produção de definições (textuais) sem ambigüidade para aqueles conceitos e relações; 
3. Identificação de termos para poder referenciar os conceitos e relações (item 1), que estejam de acordo com as definições do itern 2.

\subsubsection{Codificagão}

Entende-se por codificação, uma representação explícita da conceitualização capturada na etapa anterior em alguma linguagem formal. Isto envolve as seguintes etapas:

- Considerar os termos básicos que serão usados para especificar a ontologia (por exemplo: class, entity, relation); freqüentemente isto é chamado de meta-ontologia por que esta é, em essência, uma subcamada ontológica de termos representativos que serão usados para expressar a ontologia principal.

- Escolher uma linguagem de representação (que seja capaz de suportar a meta-ontologia);

- Escrever o código.

\subsubsection{Integrando ontologias existentes}

Nas etapas de captura e/ou processo de codificação, existe a questão de se usar partes de ontologias já existentes, ou mesmo ontologias completas. De forma geral, este é um problema dificil. Alguns progressos importantes nesta área estão descritos em (Farquhar et. al., 1995) e (Skuce, 1995). O ponto principal de Skuce é que, para chegar a um acordo entre as ontologias que podem ser compartilhadas entre vátios usuários da comunidade, deve-se trabalhar muito para compatibilizá-las.

De forma geral, fornecer orientações e ferramentas nesta área, pode ser um dos maiores desafios no momentp de desenvolver metodologias abrangentes para construir ontologias. É fácil identificar sinôtimos e estender uma ontologia quando não existe nenhum conceito prévio. Porém, quando existem conceitos similares já definidos em ontologias existentes, não fica claro "como" e "se" tais conceitos podem ser adaptados e re-utilizados.

\subsubsection{Avaliação}

Gómez-Pérez (Gómez-Pérez et. al., 1995) fornece uma boa definição de avaliação no contexto de compartilhamento de conhecimento: 
"Para fazer uma apreciação técnica sobre as ontologias, precisa-se que o software associado, e a sua documentação estejam em relação a um framework de referência. Este framework de referência pode conter especificações de requisitos, questões competentes, e/ou aspectos do mundo real.“

Alguns detalhes sobre avaliação de ontologias que foram feitas, que poderiam contribuir para uma metodologia abrangente para construir ontologias, e outras informações podem ser encontradas em (Gómez-Pérez, 1995; Gómez-Pérez, 1996; Gruninger \& Fox, 1995).

\subsubsection{Documentação}

Segundo Uschold e Gruninger (1996), pode ser desejável estabelecer diretrizes para documentar ontologias conforme o tipo e propósito da ontologia.

Como foi mencionada por Skuce (1995), uma das principais barreiras para efetivar o compartilhamento de conhecimento é a insuficiente documentação existente sobre as bases de conhecimentos e as ontologias. Para se resolver este problema, devem ser documentadas todas as premissas importantes sobre os conceitos principais definidos na ontologia, bem como as primitivas usadas para expressar as definições na ontologia.

\subsubsection{Indicações iniciais para projetar ontologias}

Uma metodologia abrangente para construir ontologias deve incluir também um conjunto de técnicas, métodos e princípios para cada um das quatro etapas apresentadas anteriormente, como um bom indicador das relações entre as etapas.

Uma tentativa de consolidar a experiência, que se ganhou em diversos grupos de pesquisas no desenvolvimento de ontologias, é descrita em (Gruber, 1995). Um breve resumo sobre estas experiências são apresentadas na continuação, como um conjunto de critérios de projeto. A ênfase está sobre o compartilhamento e a re-utilização, e são:

a) Clareza: Uma ontologia deve comunicar efetivamente as diferentes pretensões para os usuários que projetam agentes. Isto significa que a ambigüidade deve ser mínima, deve-se dar exemplos para ajudar o usuário a entender as definições que carecem de condições. Se for possível, as definições devem ser especificadas como premissas formais. Em todos os casos, definições devem ser documentadas em linguagem natural e deve-se dar exemplos para ajudar a esclarecer o processo. 
b) Coerência: Uma ontologia deve ser consistente internamente. As premissas definidas devem ser pelo memos logicamente consistentes. Também a coerência deve se aplicar às partes das definições que não são colocadas como premissas (como a documentação em linguagem natural e seus exemplos).

c) Extensibilidade: Uma ontologia deve ser projetada antecipando o uso compartilhado do vocabulário. Este dẹve oferecer fundamentos conceituais para o conjunto de tarefas e a representação deve ser planificada de tal forma que posteriormente possa-se estender e especializar a ontologia de forma uniforme. O usuário deve ser capaz de definir novos termos baseado no vocabulátio existente, de tal forma que não se precise fazer tevisões de definições existentes.

\subsection{Considerações finais}

Neste capítulo foi apresentada a necessidade de compartilhamento de conhecimento para melhorar a comunicação entre pessoas, organizações e sistemas de software. Tal compartilhamento pode funcionat como um framenork unificador, chamado de ontologia, que pode gerar uma serie de benefícios.

Para que exista uma comunicação entre agentes de software e esta seja possível, ela deve estar baseada numa linguàgem de comunicação (discussão vista no capítulo 2), que permita a interoperação entre os agentes envolvidos. Essa linguagem deve ter como base uma ontologia comum que permita aos agentes compartilhar conhecimento através da troca de mensagens.

Uma linguagem de comunicação, a Universal Communication Language, e sua ontologia são as principais contribuiçŏes deste projeto de mestrado. 


\section{COMUNICAÇÃO ENTRE AGENTES DE SOFTWARE NA INTERNET}

\subsection{Considerações Iniciais}

A Internet tem motivado o desenvolvimento de novas tecnologias voltadas para aplicações distribuídas. No contexto da comunicação entre agentes de software, várias tecnologias têm sido propostas e estudadas, no sentido de aprimorar as técnicas existentes e permitir o desenvolvimento de aplicações cada vez mais complexas e poderosas.

Este capítulo contém uma breve descrição dessas várias tecnologias, que podem ser aplicadas na comunicação entre agentes de software, especificamente para auxiliar a descrever a implementação da lìguagem Universal Communication Language - UCL, que será vista com maior detalhe no capitulo 6. Dentro das tecnologias que serão descritas inclui-se algumas características da meta-linguagem XML e da linguagem Universal Network Language (UNL) (Uchida, 1999). Esta última é um projeto que esta sendo patrocinado pela Universidade das Nações Unidas (UNU). Além disso, é descrita a ontologia ThoughtTreasure como meio de representação conceitual.

\subsection{A linguagem UNL - Universal Networking Language}

A Universidade das Nações Unidas (UNU), sediada em Tóquio, resolveu patrocinar um projeto de longa duração - 10 anos - para o desenvolvimento de ferramentas de software, que usam uma intedíngua como representação intermediaria de mensagens, para vencer a barreira da língua pata a comunicação entre os povos. Nesse projeto, ao invés da tradução de uma língua para outa se faz a codificação do conteúdo de um texto em uma dada língua natural para uma antificial, chamada Universal Networking Language (UNL) (Uchida, 1999), criada especificamente para textos escritos para o ambiente da Internet. $O$ texto já codificado 
em UNL pode então ser decodificado para a língua destino. O projeto UNL é de âmbito mundial, sendo coołdenado pelo Instituto de Estudos Avançados, da Universidade das Nações Unidas. Nos três primeiros anos, a partir de 1997, começaram a ser desenvolvidos codificadores e decodificadores para cerca de 15 línguas, incluindo chinês, russo, alemão, francês, italiano, japonês, inglês, hindi, espanhol e português. Nos sete anos testantes previstos para o projeto UNL, espera-se atingir praticamente todas as línguas oficiais das Nações Unidas (Nunes, et.al., 1997).

O Projeto UNL busca uma integração comunicativa em um ambiente de processamento automático de linguagem natural (PALN) integrado em rede, que permitirá que usuários de qualquer parte do mundo possam se comunicar sem que, para isso, tenham que aprender uma linguagem especial de comunicação (Uchida, 1999).

\subsubsection{O léxico segundo a perspectiva da UNL}

Os componentes do léxico da UNL incluem conceitos padrões ou Universal Words (UWs) e um conjunto de relações conceituais e atributos que podem ser expressos estruturalmente, em termos de relaçõos sentenciais. Essas relações são rotuladas adequadamente, por meio de "rótulos de relações" (Relation Labels - RLs) e "rótulos de atributos" (Attribute Labels - ALs) (Uchida, 1999). As UWs são baseadas principalmente em palavras da língua inglesa e são relacionadas segundo as relações hierárquicas da taxonomia conceitual ou segundo os rótulos de relacionamento sentencial fornecidos por um usuário especialista. Dessa forma, o léxico forma uma hiper-rede de relações entre UWs que abrange conceitos genéricos e específicos, indicando parte de seu in ter-relacionamento semântico (Nunes et. al., 1999).

Assim, como se faz uso de RLs para se chegar ao significado pertinente e, logo, a uma UW particular, faz-se uso dos ALs para limitat o significado das UWs. Desse modo, o uso dos componentes sentenciais indica a semântica lexical incorporada ao léxico. Uma descrição completa dos componentes da linguagem UNL é feita no Apêndice A.

\subsubsection{As palavras universais (UWs)}

A função de uma UW é denotar um significado específico. Sua representação genérica é um tótulo simples (que indica o significado genérico de uma palavra em inglês). Cada UW é tepresentada por uma palavra inglesa que contém o significado genérico na língua inglesa, acompanhada de restrições de maneira que essa mesma palavra inglesa possa gerar várias UWs. Consequentemente, a ambigüidade devido à homografia é eliminada. Por exemplo, a 
palavra "book" tem|várias UWs a ela associadas, para indicar os seus vários significados, como em :

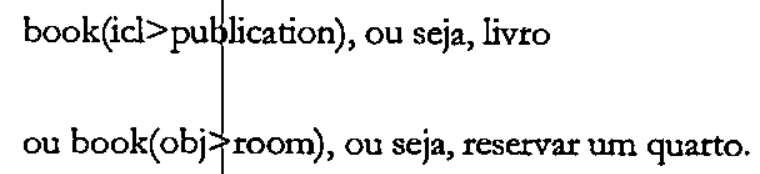

Para este exemplo deve-se considerar que a UW book esta associada com outras UWs como "publication" e "room", além disso para auxiliar na definição de uma UW se utilizam rótulos de relação como "icl' e "obj” que serão descritos no próximo tópico.

Por tanto, a UW "book" contém todos os significados possiveis, ao passo que as outras com restrições servem para desambigüização (Nunes, et.al., 1997). Observa-se no exemplo que a restrição "(icl>publication)" limita o significado da palavra book referindo esta a uma publicação. A outra testrição “(obj>room)" indica que a palavra book está relacionada com a reserva de um quarto.

\subsubsection{Os rótulos de relação (RLs)}

A UNL inclui atualmente cerca de 35 relações semânticas. Os RLs expressam relações binárias entre significados, ou seja, UWs. Sua representação genérica é um par do tipo relation_label (UW1, UW2), onde UW1 e UW2 são interrelacionadas através da relação semântica denotada pelo RL. Há varias classes de RLs que podem ser associadas a dois componentes da sentença, ou 2 UWs. Um exemplo é a relação (agente-objeto), em que o agente (agt) é um objeto animado que causa uma ação volitiva. Outros RLs incluem método (met), tempo (tim), beneficiário (ben), possessão (pos). Os RLs também são empregados para relacionar UWs na restrição de significados, como inclusão (icl) para representar hiperonímia, como em icl (dog, arimal) ou sinônimo (equ) para representar significados equivalentes entre Uws (Nunes, et.al., 1997).

\subsubsection{Os rótulos de atributos (ALs)}

Os rótulos atributivos (ALs) são empregados para restringir o significado genérico de uma UW. Informações como tempo, aspecto e intenção também são representados como ALs. Um AL é representado por uma UW seguida de atributos identificados pelo símbolo “@”. Por exemplo, uma UWW com $n$ atributos tem a forma: 
propriamente ditas. Tais informações são conhecidas em conjunto como markupp (marcação) (McGrath, 1999). Existem várias linguagens de marcação patenteadas usadas em pacotes de processadores de texto como também existem linguagens de marcação abertas e sem patentes, como TeX, Troff, e a conhecida HTML (HyperText Markup Language - linguagem de marcação de hipertexto).

Nesse contexto surgiu a linguagem XML (eXtensible Markexp Language) que também é uma linguagem de marcação com vantagens importantes sobre as já citadas. As linguagens de marcação, em sua maioria, são "fixas". O que equivale dizer que elas oferecem um certo conjunto de recursos em sua marcação, e esse conjunto é definido no modelo da linguagem. A XML, por outro lado, não define qualquer conjunto de recursos de marcação em particular. Ao invés disso, ela oferece uma estrutura padrão que possibilita a cada usuário criar sua própria estrutura ou usar outras definidas por terceiros (McGrath, 1999).

A linguagem XML, surgiu como uma forma simplificada da SGML (Standard Generalized Marked Language). A SGML é um padrão muito poderoso e geral, mas muito complexo. A SGML foi proposła para solucionar um problema compartilhado por instituições, pesquisadores e empresas que necessitavam manipular e realizar o intercâmbio de documentos eletrônicos. A SGML foi desenvolvida de modo a permitir que os documentos pudessem ser escritols com sua própria gramática e formato, legiveis por seres humanos e manipulados de modo eficiente por aplicações computacionais. A XML é um subconjunto da SGML que pretende torná-la "leve" o suficiente para o uso na Web (McGrath, 1999) em muitos casos substituindo a HTML. Isso se dá porque, apesar da linguagem HTML ser muito simples e utilizada etn diversas aplicações, existem algumas desvantagens relacionadas à sua flexibilidade como (J hhnson, 1999; Mace et al., 1998):

- Não é exter sível, ou seja, não é possível especificar e criar novos elementos e atributos pafa situações específicas e, desta forma, indicar o significado da informação;

- É uma linguagem boa para propósito de exibição, mas não para aplicação de dados, pois ela reptesenta a informação em termos de seu layout e não através do seu significado; 
- Possui poucá ou nenhuma estrutura semântica, pois seus elementos são agrupados sem seguir nenhuma estrutura pré-definida, o que torna dificil de encontrar o que se esteja procurando na Internet.

Devido a estas e outras desvantagens, torna-se evidente que a HTML atualmente não é suficiente para a especificação e o suporte à variedade de aplicações existentes na Internet. Já a SGML não possuil essas desvantagens, mas é muito complexa. Assim, é necessário obter uma linguagem podetosa quanto a SGML e simples como a HTML. Foi com esse intuito que o grupo de trabalho \$GML criou o novo padrão chamado XML (Extensible Markup Language) (Connolly, 2000).

\subsubsection{XML como uma meta-linguagem}

O objetivo da XML é fornecer muitos beneficios encontrados em SGML e não disponíveis em HTML. Além disso, ser fácil de aprender e usar se comparada com a complexa linguagem SGML (Mace et. al., 1998; MCGrath, 1999). A XML é definida como um subconjunto da SGML e oferece uma abordagem padrão para descrição, captura, processamento e publicação de informações.

Em XML, os desenvolvedores podem criar seus próprios elementos de acordo com a aplicação que está sendo modelada, dando importância ao conteúdo e à estrutura da informação, sem se preocupar com a apresentação. A linguagem descreve uma classe de objetos de dados (documentos XML) e descreve, parcialmente, o comportamento de programas que os processem (Bray et. al., 2000). Esse processamento é realizado através de dois módulos. O primeiro é chamado de processador XML e é usado para ler um documento XML e fornecer acesso ao seu conteúdo e estrutura. A tarefa fundamental do processador $\mathrm{XML}$ é interpretar (parse) os dados, ou seja, refere-se ao processo por meio do qual os caracteres que formàm o documento XML são categorizados como marcação ou dados de caracteres. O processador envia essas informações para o segundo módulo (aplicação XIML), ou seja, ele trabalha em beneficio da aplicação, como mostra a Figura 4.1 (McGrath, 1999) 


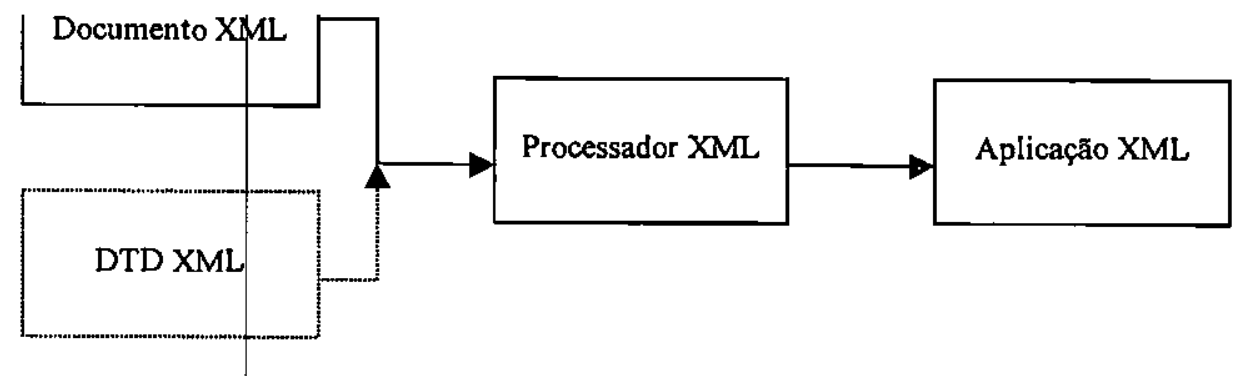

Figura 4.1 Sistema baseado em XML.

Um documento XML pode estar associado a um conjunto de regras que limitam o tipo do conteúdo das informações que podem estar contidas nesse documento. Essas regras encontram-se em un DTD (Document Type Definition) e o fato de ser mostrado por linhas pontilhadas na figura 4.1 indica que ele é opcional. A seguir, é detalhado o conceito de DTD e como se ele se relaciona com XML.

\subsection{2 $O$ Documento que define as regras para XML}

Um DTD (Document Type Definition) define regras para a especificação de uma classe de documentos, tais como (Trindade, 1997):

- que tipos de elementos podem existir em um documento (por exemplo, Aluno, Professor, Curso);

- que atributos esses elementos podem ter (por exemplo, um Curso é formado pelos elementos Nome_Curso, Professor, Período, Alunos);

- como as instâncias desses elementos estão hierarquicamente relacionadas (como por exemplo, um Curso possui Alunos e cada Aluno possui um Id (Identificação_Curso), Nome, Email, Homepage e Notas, que por sua vez podem conter várias Notas e uma Nota final).

A estrutura especificada em um DTD, segundo sua definição no padrão XML, possui uma propriedade importante: apenas a estrutura lógica de um documento é descrita, não sendo fornecida informação sobre a apresentação dos elementos definidos (Brown, 1989). 
Se o documento XML estiver associado a um DTD, o Interpretador deve verificar se o documento XML está correto (validação). Para isto, o Interpretador processa o DTD que corresponde ao documento XML e obtém sua estrutura. Posteriormente, o Interpretador obtém as informações do documento XML realizando a validação com a estrutura definida no DTD. Por outro ado, se o documento XML não está associado a um DTD, então apenas a sua estrutuma sintática pode ser verificada (sem validação).

\subsubsection{Acesso e Manipulaçăo de documentos XML com Java} As APIs (Aplication Programming Interface) SAX (Simple API for XML) e DOM (Document Object Modeל são recursos que podem ser utilizados por desenvolvedores Java que precisem manipular e apresentar documentos XML suportados por suas aplicações. Esses recursos, comentados a seguir, são os mais explorados na literatura para estes propósitos.

\subsubsection{API SAX}

A API SAX (Simple API for XML) foi criada para permitir o acesso à informação armazenada em documentos XMY em qualquer linguagem de programação (Megginson, 1998). Ela provê esse acesso não como uma árvore de nós, mas como uma seqüência ordenada de eventos. A aplicação interpreta esses eventos de uma maneira significativa e cria o seu próprio modelo de objetos baseada nestes eventos. Assim, bibliotecas que implementam a API SAX tomamse mais rápidas e simples, porém as aplicações que usam essa interface precisam atender das seguintes condições (Idris, 1999):

- criação de seu próprio modelo de objetos personalizado;

- criação de una classe que capture os eventos SAX (gerados pelo Interpretador SAX conforme ele processa um documento $\mathrm{XMI}$ ) e crie adequadamente o modelo de objetos.

Uma vantagem de SAX é que o documento inteiro não fica residente na memória, o que é interessante em situações onde há processamento de documentos gigantes. O Interpretador SAX percorrem um documento XML ativando métodos que tratam de cada caso, como, por exemplo, início, conteúdo e fim de elemento.

A API SAX é mais adequada para propósitos onde é preciso ler um documento $\mathrm{XML}$ completo do início ao fim e executar alguma tarefa, tal como construir uma estrutura de 
dados que represente um documento ou resumir a informação contida em um documento. SAX não é muito útil em casos onde se deseja modificar a estrutura do documento de alguma forma complicada que envolva troca de elementos que estão aninhados. Desse modo, a API SAX é recomendada em casos onde a informação é estruturada de tal maneira que seja mais fácil criar um mapeamento próprio que representar a informação como uma árvore (Idris, 1999).

\subsubsection{API DOM}

O poder da XML está na sua capacidade de representar a estrutura da informação baseada em como cada parte dessa informação se relaciona com as demais (Bray et al., 2000). Os documentos estruturados têm a propriedade de poder ser aninhados um dentro do outro, apresentando uma estrutura em forma de árvore.

A API DOM (Document Object Model) fornece uma interface independente de plataforma e linguagem para a estrutura e o conteúdo de documentos H'TML e XML. Ela descreve uma linguagem neutra capaz de representar qualquer documento XML bem formado em forma de uma árvore e tratar a informação armazenada nesses documentos como um modelo de objetos hierárquicos (Idris, 1999). A API DOM cria uma árvore baseada na estrutura e na informação do documento, sendo que o acesso à informação pode ser feito através de interações com os nós dessa árvore.

A API DOM busca fornecer um modelo padrão único na forma como são organizados os diversos objetos que formam os documentos. Ela também busca padronizar uma interface desses objetos para facilitar a navegação em documentos e o processamento destes.

Os principais objetivos de projeto do modelo DOM são (McGrath, 1999):

- fornecer um 'conjunto de objetos e interfaces suficientes para representar o conteúdo e a estrutúa dos documentos HTML e XML sem perda de informações significativas;

- realizar isso de uma forma independente de plataforma e linguagem;

- fornecer funcionalidade de criação de objeto poderosa o suficiente para permitir que documentos HTML e XML sejam criados completamente a partir do zero; 
- fornecer umá base sólida e extensível na qual podem ser adicionadas novas camadas DOM no futuro.

Diferentemente da API SAX, no modelo DOM o Interpretador faz quase tudo: lê o documento, cria um modelo de objeto em uma linguagem (nesse trabalho, em Java) e fornece uma referência para este modelo de objeto ser controlado (Idris, 1999).

Com o uso do modelo DOM, os usuários se beneficiam de uma interface homogênea tanto para HTML como para XML. E ainda é possível fazer a transformação de um documento XML para HTML, por exemplo, utilizando as especificações XSL (Extensible Stylesheet Language) (XSL, 2000).

Uma alternativa para manipular e apresentar documentos XML é utilizá-los como objetos ou tratá-los como uma seqüência de eventos. Isso porque, uma vez que os elementos de um documento estruturado estão aninhados, estes podem ser representados como uma estrutura em árvore (os objetos são os nós da árvore) ou uma seqüência ordenada de eventos. Exemplos: a Figura 4.3(a) apresenta a hierarquia do documento HTML da Figura 4.2 em forma de nós em una estrutura de árvore: o elemento $\langle$ TBODY $>$ é filho de $\langle$ TABLE $>$, o elemento $<$ Over the River, Charlie $>$ é filho do elemento $\langle\mathrm{TD}\rangle$, que por sua vez, é filho à esquerda do elemento $<\mathrm{TR}>$ que, por sua vez, é filho à direita do elemento $<\mathrm{TBODY}>$. Já a Figura 4.3(b) apresenta os elementos HTML da Figura 4.2 como uma seqüência ordenada de eventos: 1) start table, 2) start element:tbody, 3) start element:tr, e assim sucessivamente.

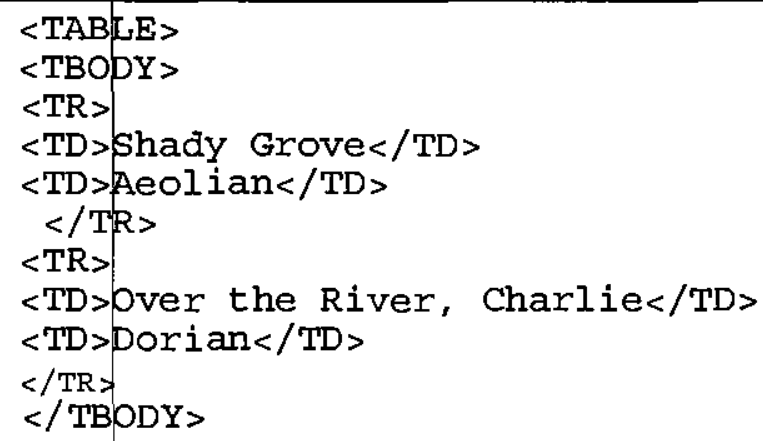

Figura 4.2 - Estrutura do HTML utilizado no exemplo (DOM, 1998) 


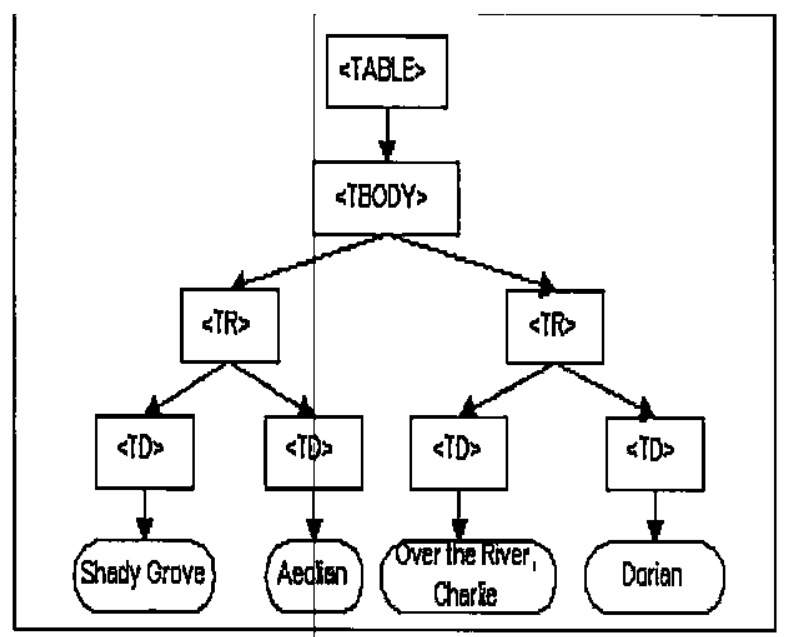

Figura 4.3 - a) Estrutura baseada em árvore (API b) Estrutura baseada em evento (API DOM) (DOM, 1998) start able

start clement thody

start clement or

start element: td

chamcters: Shady Grove

end element: to

start element id

caracteres: Aeolian

end clement: td

end element: tr

start element tr

start element: td

caracteres: Over the River, Chaadie

end element td

start element td

caracteres: Dorian

end element: td

end element: tr

end element: tbody

col elment: table

\subsection{Representação de sentenças em linguagem natural.}

No uso cotidiano da língua, a comunicação entre os falantes se dá através de textos embora esses mesmos falantes possuam uma consciência intuitiva das unidades mínimas de língua. Em termos de análise linguística, pode-se dizer que o texto é a unidade maior na estrutura de uma língua natural, pois reúne em si informações de diversas naturezas que, por sua vez constituem no objeto de estudo de alguns campos específicos na área da Linguística.

No processamento de linguagem natural (PLN) o material de processamento é um texto que deve ser analisado, ou seja, recortado em unidades menores para a compreensão completa dos mecanismos de operação envolvidos em cada dessas unidades. Assim, o PLN recorre a campos específicos da Linguística, procurando depreender da sua descrição as informações que irão fazer da máquina um instrumento sensível aos fenômenos da língua natural.

O processamento da linguagem natural tem seus inícios na semiótica, o estudo dos signos. A semiótica foi desenvolvida por Charles Sanders Peirce (logicista e filósofo) e Ferdinad de Saussure (lingüista). A semiótica é dividida em três ramificações: sintaxe, semântica, e pragmática. 
Um processador de linguagem natural completo pode extrair o significado da linguagem em vátios níveis. Quatro são os mais importantes para esse trabalho (Nunes et. al., 1999):

a) Morfológico: Palavras da língua também podem ser segmentadas em termos do seu conteúdo significativo. As unidades mínimas dotadas de significado (gramatical ou lexical) são denominadas morfemas e se constituem no objeto de estudo da Morfologia.

b) Sintático: A organização das palavras na sentença acarreta a definição desses itens lexicais em termos de suas funções gramaticais. Trata-se de reconhecer as regras pelas quais a distribuição das formas é determinada sendo esse exercício o objeto de estudo da Sintaxe.

c) Semântico: As relações envolvidas no plano do significado das palavras em busca de alcançarem certo sentido no escopo da sentença são a matéria de investigação da Semântica. $\mathrm{q}$ significado é inerente ao signo linguistico e está presente não só na palavra como uma unidade completa, mas nas suas unidades constitutivas. $\mathrm{Da}$ mesma forma, fala-se em significado de expressões, de sentenças, em fim, de unidades mais complexas da língua. Grande parte do esforço do tratamento semântico em PLN deve envolver, então, a depreensão das propriedades semânticas dos itens lexicais para a construção de sentenças semanticamente bem formadas da língua.

d) Pragmática: Nesse nível de análise linguística estão em foco as questões, consideradas por muitos estudiosos, do mundo extralinguístico. Essa noção é amparada pelo fato de que para além das formas e das estruturas, a língua recupera da situação comunicativa diversos fatores que implicam na determinação de certa compreensão das palavras \& sentenças. Todo texto é produzido por certos interlocutores, em um tempo e um lugar determinado, o que significa dizer que nenhum texto existe independente dos individuos envolvidos na atividade comunicativa e nenhum texto existe sem uma situação de contexto. Quando se examina uma construção linguística procurando essas relações presentes no ato da fala, na verdade procura-se estudar aquilo que é objeto da Pragmática. 


\subsubsection{A ferramenta Thought Treasure (TT)}

O programa Thought Treasure é uma poderosa ferramenta de processamento de linguagem natural (ferramenta de código aberto), desenvolvida por Erik T. Mueller.(1998). Esta ferramenta é capaz de interpretar linguagem natural, como também estender sua base de conhecimento que está baseado em ontologias. É um compilador para linguagem natural que permite extrair informação de sentenças ou frases.

O TT é formado por uma base de dados de 25,000 conceitos organizados hierarquicamente (Mueller, 1998). Por exemplo, Evian é um tipo de flat-water, o qual é um tipo de drinking-water, o qual é um tipo de fod e assim por diante.

Cada conceito tem uma ou mais aproximações sinônimas, o programa chega a um total de 55,000 palavras e frases do idioma inglês e francês. Por exemplo, como se vê na Figura 4.4, associações com o conceito food no idioma inglês são as palavras food e foodstuffs e em francês aliment e nourriture (entre outras).

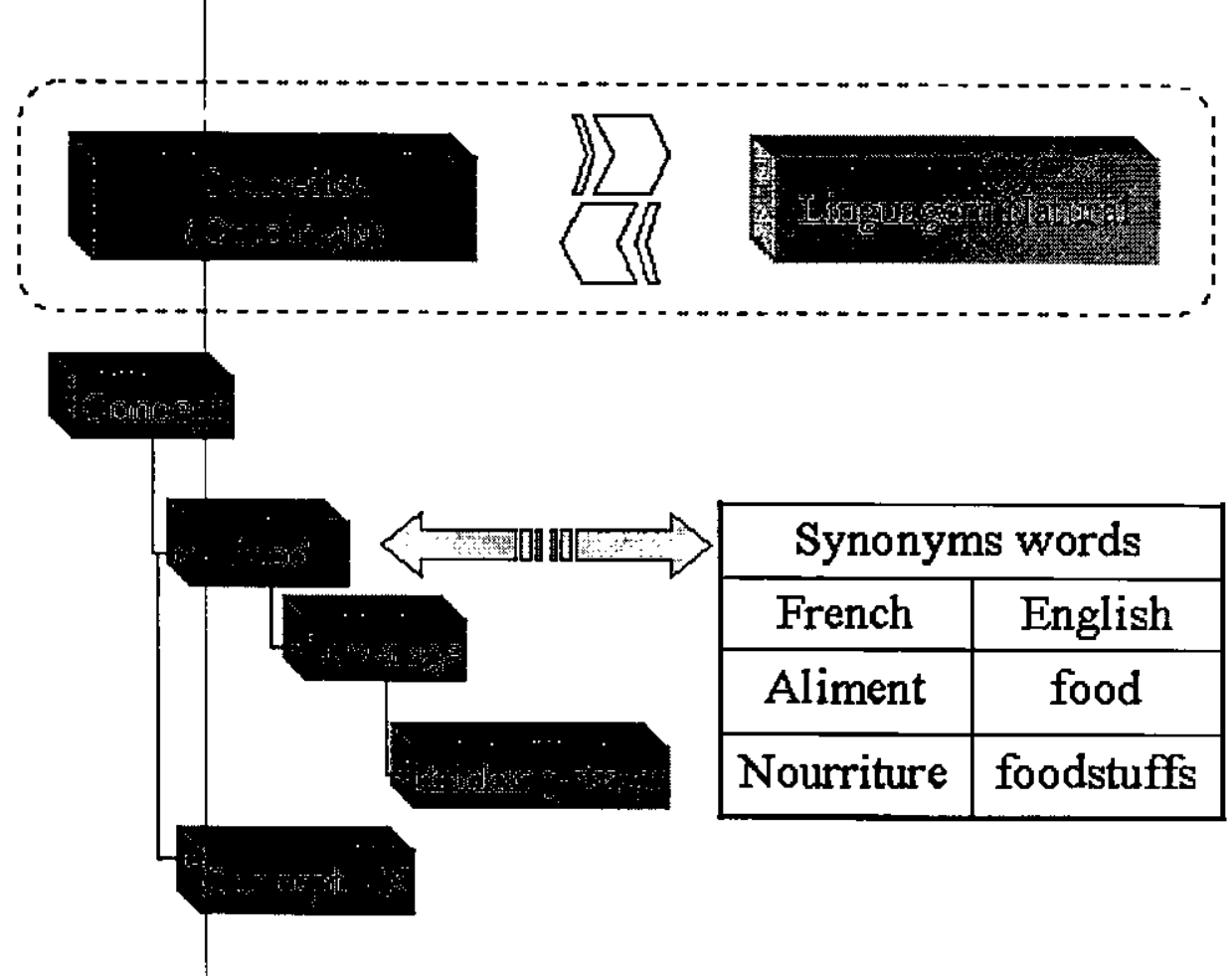

Figura 4.4 Associação da ontologia com a linguagem natural.

O programa ThoughTreasure tem aproximadamente 50,000 asserções relacionados a conceitos, assim como: a green-pea is a seed-vegetable, a green-pea is green, a grean-pea é parte de pod-of-pea, pod- 
of-peas é encontrado geralmente em uma loja de comestiveis. ThougTreasure tem ao redor de 100 scripts, descrevendo atividades típicas, que permitem entender o mundo real. O programa Though Treasure compfeende sete módulos, mas esse trabalho utilizou apenas cinco deles (Mueller, 1998):

\section{Representação de agência}

Esse módulo consiste do banco de dados, procedimentos básicos e estruturas para representar conceitos, espaço, tempo, atores e contextos. Esta é mais bem entendida através da Figura 4.5, que mostra o formato do banco de dados do ThoughtTreasure:

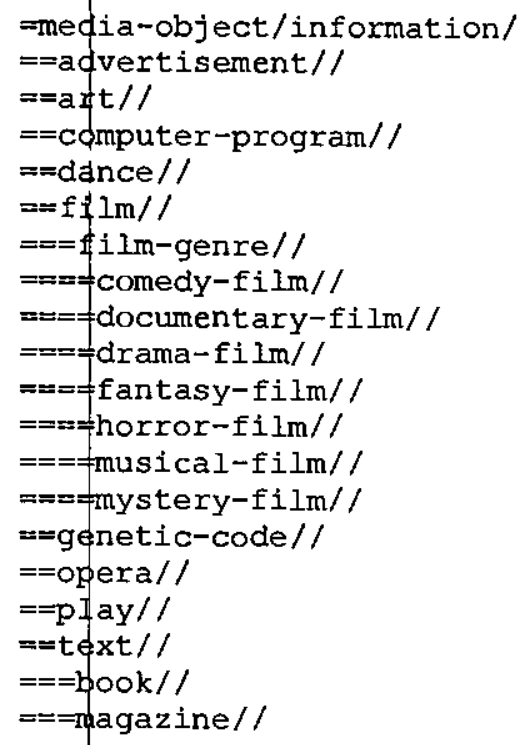

O nivel de distanciarnento das margens pelo símbolo "=" identifica a hierarquia. Neste caso, por exemplo, advertisement é um tipo de media-object. A hierarquia consiste em conceitos concretos, os quais se subdividem em entidades, situações, estados, ações, relações, atributos e enumerações.

Objetos podem ter pais explícitos representados por uma lista de conceitos, separados pelo símbolo "/". Por exemplo, media-objects tem como pai o conceito information. Conceitos no mesmo nível de hierarquia são considerados equivalentes; por exemplo, opera é equivalente a play dentro do conceito media-object. 
Um conceito amplo dentro da ontologia de ThoughtTreasure é a telação. Uma telação pode compreender subclasses, permitindo aos usuários adicionar relações de domínios específicos a suas ontologias proptietárias. A Figura 4.6 apresenta um exemplo:

-media-object-relation/relation/

$==$ author - of $/ /$

$==$ composer - of $/ /$

$==$ hewscaster $\rightarrow$ of $/ /$

$==$ piewer-of $/ /$

$==$ actor-of $/ /$

$==$ cinematographer-of $/ /$

$==$ director - of $/ /$

$==$ language - of $/ /$

$==M P A A=$ rating $-0 \mathrm{f} / /$

$==$ producer-of $/ /$

$==$ writer-of $/ /$

Figura 4.6 Relações em Thought Treasure.

$\mathrm{Na}$ Figura 4.6, o usuário define o conceito media-object-relation, que é uma relação declarada explicitamente. Assin, o usuário pode definir vátias relações para descrever o conceito mediaobjects.

O usuário pode fazer afirmações (assertions) sobre como um conceito se relaciona com outro. Por exemplo, na Figura 4.7 pode-se observar que as afirmações são codificadas na forma |relação = conceito $\mid$ e fazem parte de um conceito (neste caso, do conceito: filme The Big Lebowski)

\section{Componente Léxico}

Parte do formato da pase de dados permite que palavras sejam marcadas (com atributos) para representar características especificas de um idioma. Por exemplo: 
Esta entrada especifica que a frase medium-length film é composta por um adjetivo (A) e dois substantivos (por definição do idioma). Os símbolos "\#” significam que a palavra é usada como é (outra forma gramatical não é permitida). O símbolo "**" significa que outra forma e conjugaçăo da palavta podem ser usadas no lugar da que está especificada. Por exemplo, médium-lenght films e médium-lenght film são considerados conceitos equivalentes.

\section{Text agency}

Esse módulo é responsável por mapear ou examinar o texto de entrada em linguagem natural por palavras e frases predefinidas. Ele cria um nó para cada possível forma gramatical, coloca etiquetas nesses nós (com atributos característicos do idioma usado) e envia os resultados ao componente sintático.

\section{Componente sintático}

Este componente é responsável pela criação das árvores sintáticas a partir da saída (nós) gerada pelo módulo Text agency. Ele usa várias regras de produção e filtros para efectuar isto.

\section{Componente semântico}

Este é o mais importante de todos os módulos e consiste do parser semântico, o qual é responsável por transformat a árvore sintática em afirmações do ThoughtTreasure. Este usa várias construções gramaticais de alto nível para separar a árvore de informação em afirmações.

\subsubsection{Comparação do ThoughtTreasure com outros sistemas}

$\mathrm{Na}$ continuação, apresenta-se brevemente uma comparação do banco de dados do programa ThougbtTreasure (Mueller, 1998) em relação a outtos como: WordNet (Miller, 1995b), Cyc (Lenat, 1995), EDR (Yokoi, 1995), and LADL's electronic dictionary (Courtois \& Silberztein, 1990).

- Linguagens: Indica a quais linguagens o sistema é orientado (I = Inglês, $F=$ Francês, $\mathrm{J}=$ Japonês).

- Le: Indica o número de entradas léxicas, incluindo palavras, frases, e nomes próprios. Para sistemas bilíngües tais como ThougbtTreasure e EDR, o número mostrado representa $\circ$ total envolvendo as duas linguagens. $60 \%$ das entradas léxicas no 
ThoughTreasurp são para o inglês e $37 \%$ são para frases. $53 \%$ das entradas léxicas para LADL são frases.

- Infl: Indica o número de inflexões validadas. ThoughtTreasure contém 127,448 inflexões geradas automaticamente das quais somente 32,802 foram conferidas, em relação a qualidade e precisão do seu significado, por usuários especialistas.

- Obj: Indica ol número de conceitos atômicos.

- <lê, obj>: Indica o número de uniões (links) entre as entradas léxicas e objetos.

- Polissemia: In dica a porcentagem de entradas léxicas unidas a mais de um objeto.

- Asserções: Inqlica o número de asserções (fatos que contém conceitos atômicos) no sistema. As asserções do ThoughtTreasure que foram codificados na linguagem $C$ não são incluidas na tabela de acima.

- Esforço: Indica o número de pessoas utilizadas por ano para o desenvolvimento do sistema.

Tabela 4.1 Comparação do ThoughtTrasure com outros sistemas (Mueller, 1998)

\begin{tabular}{|c|c|c|c|c|c|}
\hline Características & $\mathrm{TT}$ & WordNet & Cyc & EDR & LADL \\
\hline Linguagens & $I, F$ & I & $I$ & $I, J$ & F \\
\hline Le & 50,133 & 118,000 & Ind & 600,000 & 170,000 \\
\hline Infl & 32,802 & Ind & Ind & Ind & 600,000 \\
\hline obj & 21,521 & 90,000 & 100,000 & 400,000 & Ind \\
\hline$\langle$ le, obj $\rangle$ & $45, \overline{739}$ & 166,000 & Ind & Ind & Ind \\
\hline Polissemia & 6.18 & $17 \%$ & Ind & Ind & Ind \\
\hline Asserçöes & 37,162 & 116,000 & $1,000,000$ & Ind & Ind \\
\hline Esforço & 2 & Ind & Ind & Ind & 100 \\
\hline
\end{tabular}

Existem campos de dados na tabela que não estavam disponíveis, em tal caso se colocou "Ind", indicando a indisponibilidade da informação. 


\subsection{Considerações finais}

Neste capítulo foram apresentados os conceitos e as principais características das tecnologias a serem usadas no projeto. Como foi citada, a XML permite definit, criar e guardar documentos, além de recuperar hierarquias de dados. Estas são características importantes, que foram consideradas para a adoção de XML neste projeto, para representar de forma conveniente às mensagens numa linguagem de comunicação para agentes. Para definir os tipos de elementos que podem ser usados numa linguagem desse tipo, assim como suas possíveis relações, um documento DTD (Document Type Definition) será usado.

Neste ponto, é importante ressaltar que este projeto não fez uso da linguagem UNL, porque esta linguagem não disponibiliza toda sua informação sobre sua linguagem. Como todas as linguagens para uso na Web (HTML, XMI, etc.) são derivadas da linguagem SGML, vai ser muito dificil que sejam escritos novos parsers para browsers (e outros softwares que compõem o WWWW que não șigam algum padrão derivado do SGML. Isso representa um grande obstáculo a adoção da linguagem UNL em browsers para o WWW, uma das metas do projeto UNL (e desse trabalho). Contudo serão usados os conceitos teóricos da linguagem UNL no desenvolvimento da linguagem de comunicação para agentes UCL, que será implementada em XIIL. A UCL também não usará a ontologia da UNL por esta não está disponível publicamente, será usada a ontologia disponível no progtama TbougbtTreasure para a representação conceltual das mensagens em UCL. 


\section{A LINGUAGEM UCL}

\subsection{Considerą̧ões iniciais}

Este capítulo contém a descrição da linguagem proposta neste trabalho para a comunicação entre agentes a UCL - Universal Communication Language. Inicialmente são situadas as características que foram consideradas para a elaboração da linguagem. Em seguida vem a metodologia que orientou o seu desenvolvimento e, por fim, a descrição completa da estrutura das mensagens especificadas nesta linguagem.

\subsection{A abordagem da linguagem UCL}

A linguagem UCL visa estabelecer uma comunicação de alto nível envolvendo agentes (de software ou humanos) com sentenças transmitidas representam de forma apropriada o domínio de conhecimento. Essa comunicação pode ocorrer:

- Via Internet: entre agentes de software e entre pessoas e agentes de softyrare (através de uma interface). Ela também pode ocorrer entre pessoas (que falem diferentes línguas) e ser mediada por agentes de software usando a UCL

- Via Linguagem Script: entre um programador, que escreve comandos em UCI, e um agente de software, que vai interpretar e executar esses comandos.

Muitos dos conceitos usados em UCL foram derivados da linguagem UNL (Uchida, 1999) e adaptados pata serem usados num ambiente XML. Algumas das principais características que guiatam a definição da linguagem foram: 
- Auxiliar a comunicação envolvendo agentes dando importância à semântica da mensagem;

- Ser de fácil utilização;

- Permitir sua integração aos padrões usados na Internet seguindo a compatibilidade com o padrão SGML, (Standard Generalized Markup Language).

Para definir uma linguagem seguindo as características acima, foi considerada a abordagem de uma linguagem baseada em mensagens (comandos) e argumentos. $O$ usuário expressa cada mensagem através de uma estrutura formada pelos conceitos relacionados ao domínio de conhecimento, esta estrutura contcm relações que envolvem estes conceitos. Além disso, cada conceito contém uma estrutura de atributos que descreve o conceito de forma que se evite a ambigüidade com outros conceitos. A linguagem UCL apresenta a vantagem de permitir uma descrị̧ão formal e semântica das mensagens. A principal desvantagem desta abordagem é exigir do usuário um aprendizado anterior sobre alguns aspectos da linguagem tais como: a sintaxe da mensagem, palavtas reservadas, notações especiais, etc.

Mesmo assim, considerou-se a utilização desta abordagem devido a importância que as mensagens têm para representar de forma mais apropriada o domínio de conhecimento. Por exemplo: um agente emissor que está em um domínio de conhecimento específico transmite uma mensagem a outro agente fazendo uma requisição de informação, o agente receptor deve saber que copceitos e características que formam a mensagem. Além do mais, considerou-se que $o$ usuário desta linguagem já tem alguma experiência no uso de computadores, bem como no uso de uma linguagem de programação, tornando-se desnecessário direcionar o usuário durante a utilização da linguagem.

Para minimizar os inconvenientes desta abordagem, bem como atender as características da linguagem listadas anteriormente, foram estabelecidos alguns critérios que devem ser seguidos na definição da linguagem:

- As mensagens, que são compostas por conceitos, atributos e suas relações, devem ser representadas de forma organizada e estruturada para que sejam de fácil leitura para o usuário. 
- Permitir a escalabilidade e extensibilidade da linguagem, de tal forma que se possa agregar novos conceitos relacionados ao domínio de conhecimento.

- Codificar a linguagem com uma meta-linguagem padrão que permita a comunicação entre sistemas heterogêneos e ao mesmo tempo que seja de fácil integração na Internet.

- Indiferença entre letras maiúsculas e minúsculas e minimização de pontuações especiais.

Incorporando estes aspectos à linguagem se pode oferecer uma representação mais legivel.

\subsection{Metodologia utilizada}

O desenvolvimento da linguagem UCL pode ser dividido em duas etapas: definição da linguagem e implementação de um programa protótipo que converte inglês para UCL e UCL para inglês.

\section{a) Definição da linguagem}

Nesta primeira fase, procurou-se especificar a linguagem, tendo como ênfase abranger os aspectos conceituais de como representar o significado das mensagens. Para esta representação, utilizou-se a base teótica da linguagem Universal Netzorking Language (UNL) (Uchida, 1999). Como foi dito anteriormente, a UNL é uma linguagem de representação semântica baseada em relações envolvendo predicados (conceitos), desta forma, a linguagem UCL proporciona os meios para descrever as mensagens.

No item 5.5 , será feita uma descrição mais detalhada desta fase.

b) Implementação do Protótipo

Utilizando a especificação inicial da linguagem, que se baseia nas características e critérios mostradas anteriormente, passou-se a preencher os aspectos gramaticais 
necessátios para a implementação de um parser para a linguagem. Para isso foi necessário:

- Estabelecer com rigor os critérios sintáticos da linguagem inicialmente definida, o que se traduziu em: definir palavras reservadas, separadores, estabelecer a gramática da linguagem;

- A utilização da meta-linguagem XML pasa definir a linguagem proposta. Esta metaflinguagem une a simplicidade da XML ao poder representativo da UNL e reduz as diffculdades de se escrever um interpretador para ela.

- Defintção da gramática (regras) em um arquivo DTD (Document Type Definition), que representa a estrutura lógica da mensagem envolvendo elementos, atributos e instâncias.

Como foi dito na introdução deste trabalho, a linguagem UNL não é adequada à filosofia de trabalho do nosso grupo, por não ser um padrão aberto, além de não derivar do padrão SGML (Standard Generalized Markup Language), o que dificulta o seu uso em programas criados para a Internet. Mas muitos dos conceitos teóricos de UNL (Uchida, 1999) foram usados por seu poder de representar mensagens. Como resultado desta fase, obteve-se uma definição da linguagem para representar mensagens relacionadas a um determinado domínio de conhecimento e um programa protótipo para conversão inglês - UCL e UCL - inglês (capitulo 6).

\subsection{Características da linguagem UCL}

A linguagem UCL representa a informação em sentenças (também chamadas de mensagens) que envolvem uma estrutura sintática e um conjunto de conceitos, telações e atributos que são definidos a seguir:

- UW (Univera! Word), que representa o significado de uma palavra ou conceito.

- Rótulo de relação, que representa uma relação entre Universal Words. 
- Rótulo de attibuto, que contém alguma informação adicional ou definição que se acrescenta à Universal Word e que está presente na mensagem.

Considerações gerais sobre a linguagem:

- Para que a linguagem proposta cumpra com a característica relacionada à representação semântica da mensagem, considerou-se a utilização de uma ontologia que define formalmente o domínio de conhecimento.

- A ontologia usada foi a definida no programa ThougbtTreasure já que a linguagem UNL tambépn não dispõe de uma ontologia explícita e aberta, $O$ vocabulário da linguagem corresponde a todas as entradas léxicas da Ontologia que usa o programa ThoughtTreasure.

- Considerando-se que as mensagens devem evitar ambigüidade, cada Universal Word (representaçấo de um conceito) é limitada na abrangência de seu significado por meio do uso de rótulos de relação. Desta forma evita-se que dois conceitos se justaponham.

- Definidos os conceitos que pertencem à mensagem, é necessário relacioná-los, utilizando rófulos de relação, para terminar a construção de uma mensagem.

\subsubsection{A notação utilizada}

Como foi visto anteriormente, a XML é uma meta-linguagem usada para definir outras linguagens. Para definir uma linguagem baseada em XML pode ser usado um arquivo contendo as regras de um DTD específico. A sintaxe de um DTD é essencialmente uma gramática de livre contexto, tal como, a forma BNF estendida (Backus Naur Form) usada para descrever linguagens de computador (Grosof \& Labrou, 1999).

Considerando que a linguagen UCL é baseada na meta-linguagem XML, a gramática formal da UCL é especificada utilizando-se a notação definida para DTDs. A seguir descreve-se brevemente alguns elementos dessa notação (Pimentel et. al, 1999): 
Element (elemento): Define os elementos do documento XML. Cada elemento tem um tipo, identificado por um nome e pode ter um conjunto de especificações de atributos a ele associado. Cada espeçificação de atributo compõe-se de um par nome/valor.

Attrlist (atributo): Un elemento pode ser classificado qualitativamente através de atributos. Um atributo é um par (nome, valor) presente no inicio de cada rótulo de elemento. Um atributo não pode aparecer mais de uma vez no mesmo elemento.

Entity (entidade): Em um documento, referências a outras entidades podem ser externas ou internas; uma referência a uma entidade acontece na forma \&nome_da_entidade; Entidades externas se referem a arquivos contendo documentos, imagens, etc. Entidades internas normalmente se referem a variáveis internas.

CDATA : Uma seção CDATA permite a inclusão de trechos que, contendo caracteres reservados para marcação, devem ter seu conteúdo ignorado pelo processador.

\subsection{Especificação da linguagem}

\subsubsection{UW (Universal Word)}

A Universal Word (UW) é a unidade mínima que representa um conceito, estas em conjunto denotam o significado específico de uma mensagem. $\mathrm{Na}$ sua representação são usadas palavras em inglês (algumas em japonês), que representem (o melhor possível) o significado ou conceito que a UW envolve.

Quando existe a necessidade de representar um conceito de forma mais exata, a linguagem possui métodos para que o conceito seja restrito no momento da definição de seu significado. Estes métodos são os rótulos de relação e rótulos de atributo que serão mostradas nos tópicos seguintes. Na Figura 5.1 é mostrada a estrutura (sintaxe) geral de uma Universal Wort.

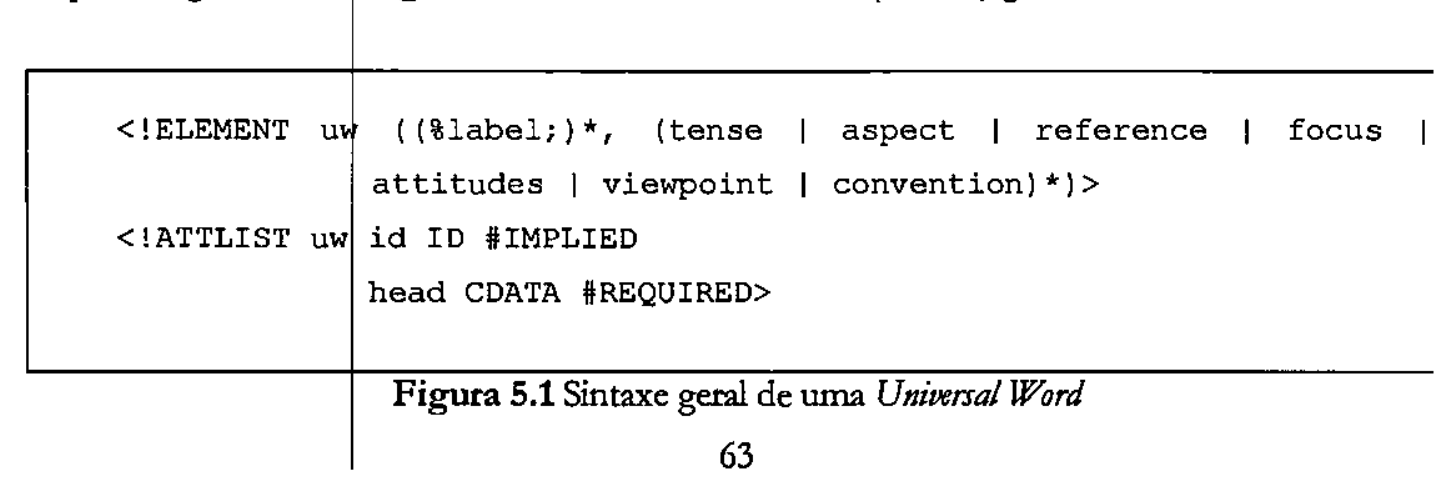


Na estrutura mostrada na Figura 5.1, pode se observar que cada uw definida deve ter um identificador id. Este identificador será formado por uma cadeia de caracteres alfanuméricos e servirá como único identificador do conceito em toda a mensagem. Este identificador pode ser referenciado em qualquer outra parte da mensagem, mas não pode ser redefinido.

O rótulo head corresponde ao lugar onde o conceito será incluído. Os conceitos utilizados sempre estarão relacionados à ontologia que se esteja usando, deste modo é neste ponto que a linguagem UCL se relaciona com a ontologia de um domínio especifico de conhecimento.

Na Figura 5.2 é apresentado um exemplo de documento UCL com a definição de conceitos, utilizando a sintaxe da Figura 5.1:

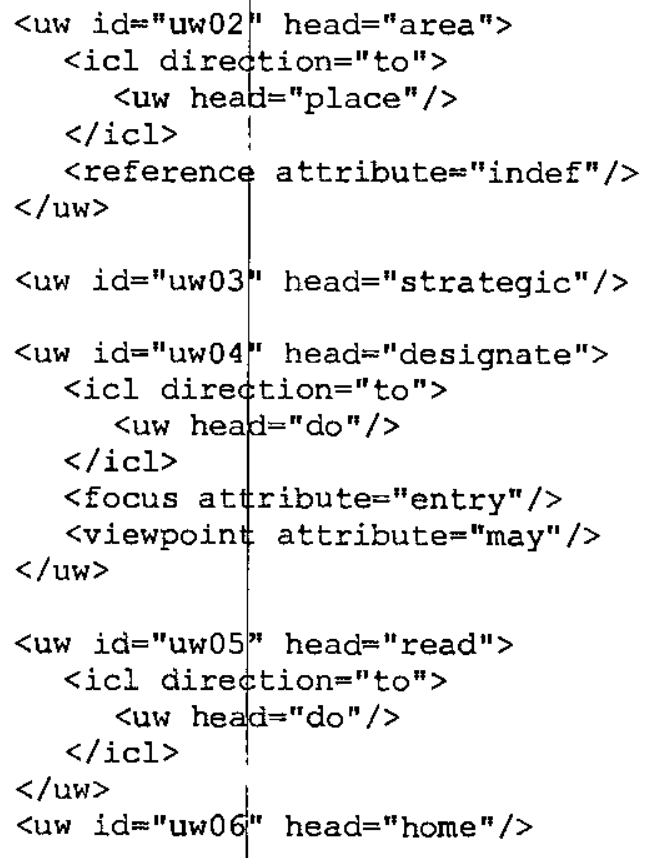

Figura 5.2 Definição de conceitos em um documento XML

Neste exemplo, pode-se observar a definição de cinco conceitos, cada um rotulado como uma uw. Cada conceito tem um identificador único no atributo $i d$, e um conceito básico no atributo head. Os rótulos de relação e atributo mostrados na estrutura são explicados nos tópicos seguintes. 


\subsubsection{Rótulos de relação}

A linguagem UCL representa mensagens que possuem um determinado significado envolvendo vários conceitos. Esta composição de conceitos é representada por um conjunto de relações binárias que permitem distinguir as diferentes relações envolvendo esses conceitos.

Em concordância com a teoria usada na definição da linguagem UNL para a representação de composição de conceitos, adotou-se os rótulos de relação definidos nessa linguagem. Estes rótulos estão formados com, no máximo, três caracteres de comprimento.

A sintaxe geral de um rótulo de relação é mostrada na Figura 5.3:

$$
<\text { !ENTITY }
$$

\section{Figura 5.3 Sintaxe geral de um Rótulo de relação.}

Os rótulos de relação estão representados por ơlabel; A seguir, mostra-se a lista e uma breve definição de cada uma das instancias de zlabel; .

- Icl (inclusão) representação de hiperonímia (super e subclasses) ou meronímia (relação parte-todo). Neste rótulo de relação se encontra o atributo "direction='to" que indica a relação parte-todo."

- Agt (agente), define um agente que causa uma ação volitiva, por exemplo, um objeto animado com intenções. 
And (união) define uma relação de conjunção envolvendo dois objetos ou conceitos. Aoj (objeto atributivo) define um objeto de um atributo.

Bas (para expressar grau) define um objeto usado como a base para expressar um grau de comparação.

Ben (beneficiário) define um beneficiário que está indiretamente relacionado com outro objeto ou evento.

Cag (concomitância/co-agência) define um objeto (não evidente) que inicia implicitamente um evento de forma simultânea.

Cao (concomitância/co-objeto com atributos) define um objeto (não evidente) dentro de um estado, efetuando-se de forma simultânea.

Cnt (conteúdo) define um conceito equivalente.

Cob (concomitância/co-objeto afetado) define um objeto que está diretamente afetado por um evento implícito de forma simultânea ou por uma condição.

Con (condição) define uma condição que causa (voluntária ou involuntariamente) a ocorrência de um evento.

Coo (co-ocofrência) define uma progressão simultânea de eventos.

Dur (duração) define um período de tempo de existência de um estado ou evento.

Fnt (alcance) Origem-destino) define uma abrangência de objetos ou eventos.

Frm (origem) define a origem de um objeto.

Gol (objetivo: estado final) define o local (fisico ou lógico) de um agente/objeto relativo a um evento.

Ins (instrumento) define o instrumento utilizado para levar a cabo um evento.

Man (maneira, modo) define a maneira de levar a cabo um evento ou caracterizar um estado.

Met (método) define um método para levar a cabo um evento.

Mod (modificador) define um objeto evidenciando-o de forma restrita.

Nam (nome) define o nome de um objeto.

obj (objeto afetado) define um objeto que está diretamente afetado por um evento ou estado.

Opl (lugat opjetivo) define um lugar onde um evento acontece.

Or (disjunção) define uma relação de disjunção entre dois conceitos. 
- Per (proportção, taxa ou distribuição) define uma base ou unidade de proporção, taxa ou distribuição.

- Plc (lugar) define o lugar onde acontece um evento ou está presente um objeto com um estado determinado.

- Plf (lugar inicial) define o lugar onde um evento começa ou define o lugar onde um estado começa a ser verdadeiro.

- Plt (lugar final) define o lugar onde um evento termina ou define o lugar onde um estado comeda a ser falso.

- Pof (parte-de) define um conceito que forma parte de outro.

- Pos (possuidor) define o possuidor de um objeto.

- Ptn (companheiro) define um objeto de forma não evidente, mas imprescindível para que se comece uma ação.

- Pur (propósito ou objetivo) define o propósito ou objetivo de um agente relacionado a um evento ou o propósito de um objeto que existe.

- Qua (quantidade) define a unidade associada à quantidade de um objeto ou grau de mudança.

- Rsn (razão) define a razão pela qual um evento ou um determinado estado aconteceria.

- Scn (cenário) define um mundo virtual onde acontece um evento, ou um estado se torna verdadeiro, ou onde um objeto existe.

- Seq (seqüêrncia) define um evento ou estado prévio ao evento ou estado que está sendo evidenciado.

- Src (estado inicial) define o local (físico ou lógico) ou estado de um agente/objeto relativo a um evento.

- Tim (tempo) define o tempo em que acontece um evento ou o tempo em que um estado é válido.

- Tmf (tempo inicial) define o tempo em que um evento começa ou o tempo inicial em que um estado começa a ser verdadeiro.

- Tmt (tempo final) define o tempo em que um evento termina ou o tempo em que um estado se torna falso.

- To (destino) define o destino de um objeto. 
- Via (lugar du estado intermediário) define o lugar ou estado intermediário de um evento.

Esses são todas os rótulos de relação incluídos na linguagem que foram definidos até o momento. Um exemplo utilizando rótulos de relação mostra-se na Figura 5.4 uma mensagem representa da na linguagem UCL, construídas a partir das seguintes sentenças.

UNL is a compon language that would be used for network communications

No exemplo apresentado na Figura 5.4, pode-se observar nas primeitas linhas a definição do arquivo Sentence.dtd, que validará a mensagem com a gramática definida. No seguinte tópico, mostrat-sc-ão os rótulos de atributos utilizados na UCL.

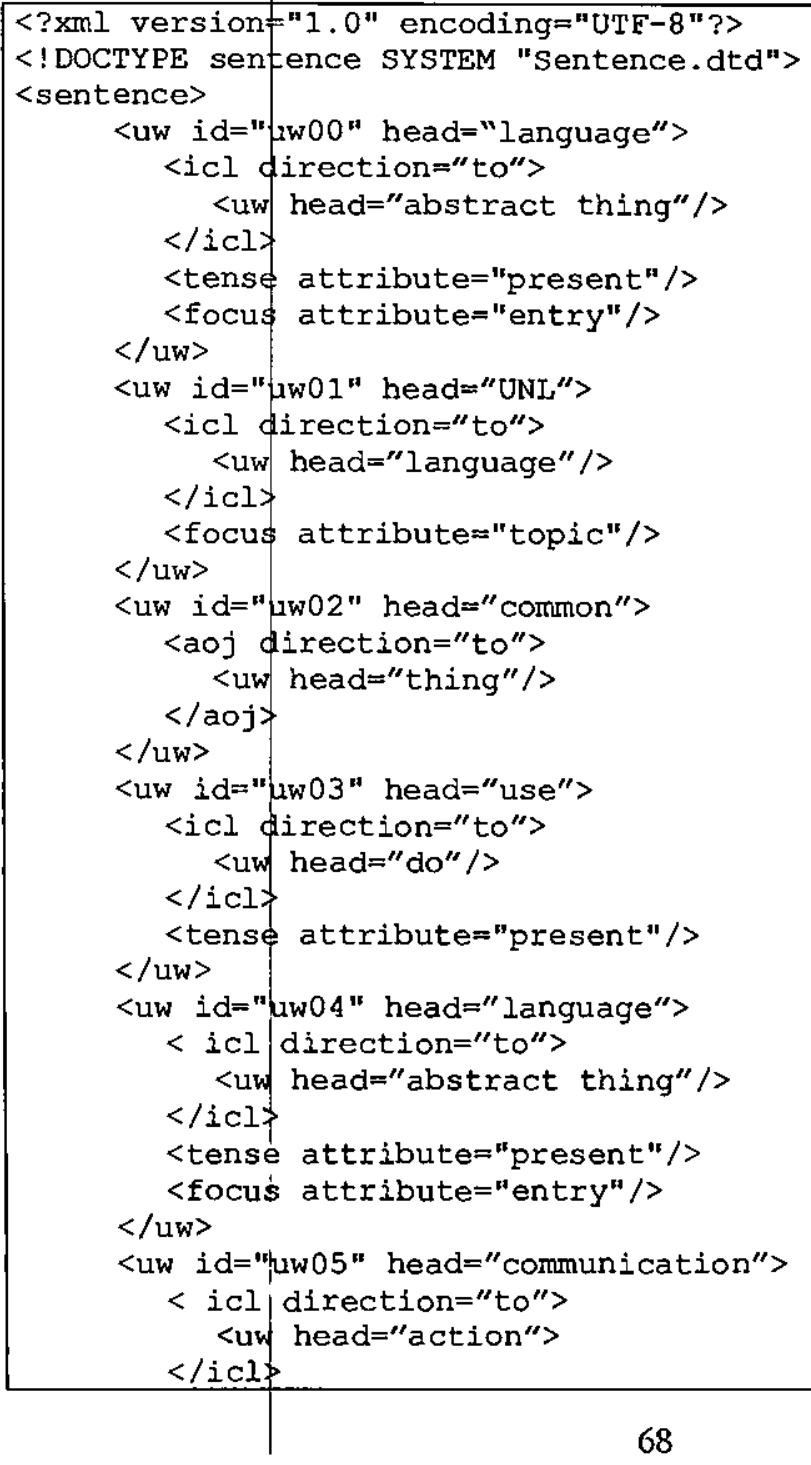




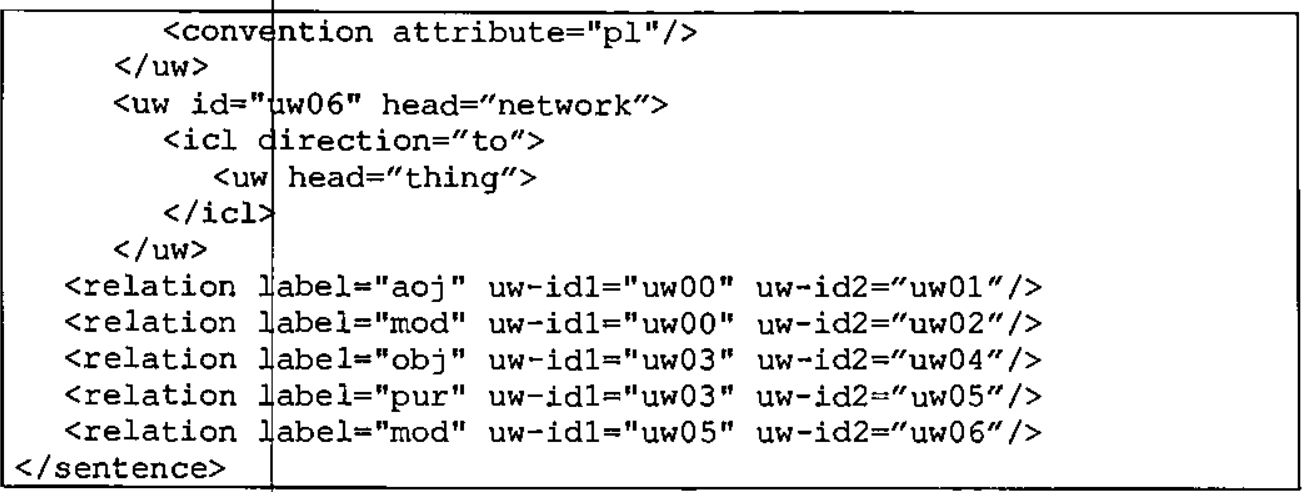

Figura 5,4 Definição de Rótulos de relação em um documento XML

\subsubsection{Rótulos de àtributo}

Os rótulos de atributos foram introduzidos para limitar o significado dos conceitos definidos no tópico 5.5.1. Com os rótulos de atributos pode-se particularizar o significado de uma uw. As representações destes atributos estão agrupadas de forma tal que se possa identificar as informações de tempo verbal, o aspecto do conceito ou estrutura da mensagem, entre outros. Estes rótulos podem ser inseridos dentro do escopo da tag uw (<uw $>\ldots</ u w\rangle)$ até se conseguir restringir seu significado como desejado. A sintaxe geral de um rótulo de atributo é mostrada na Figura 5.5.

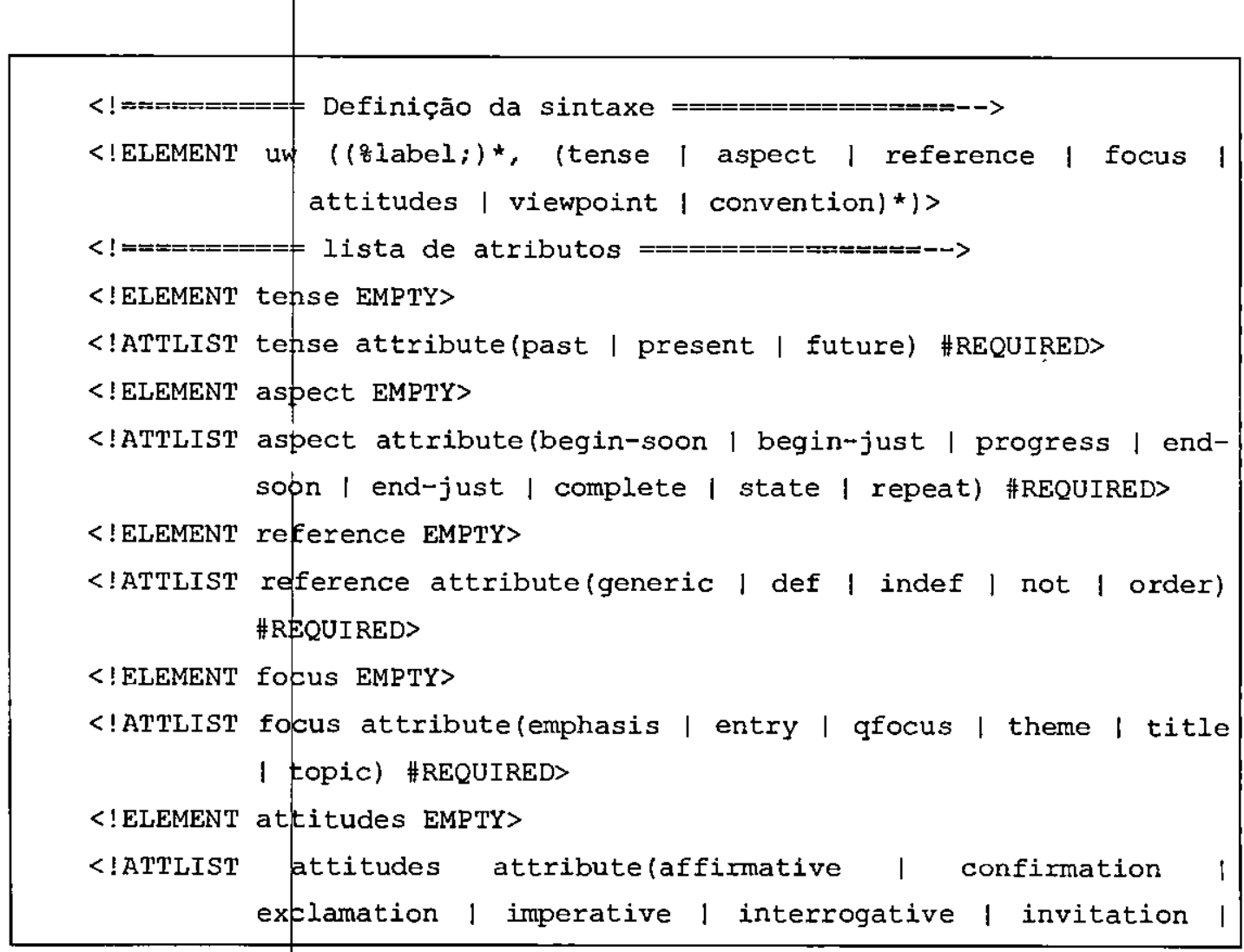




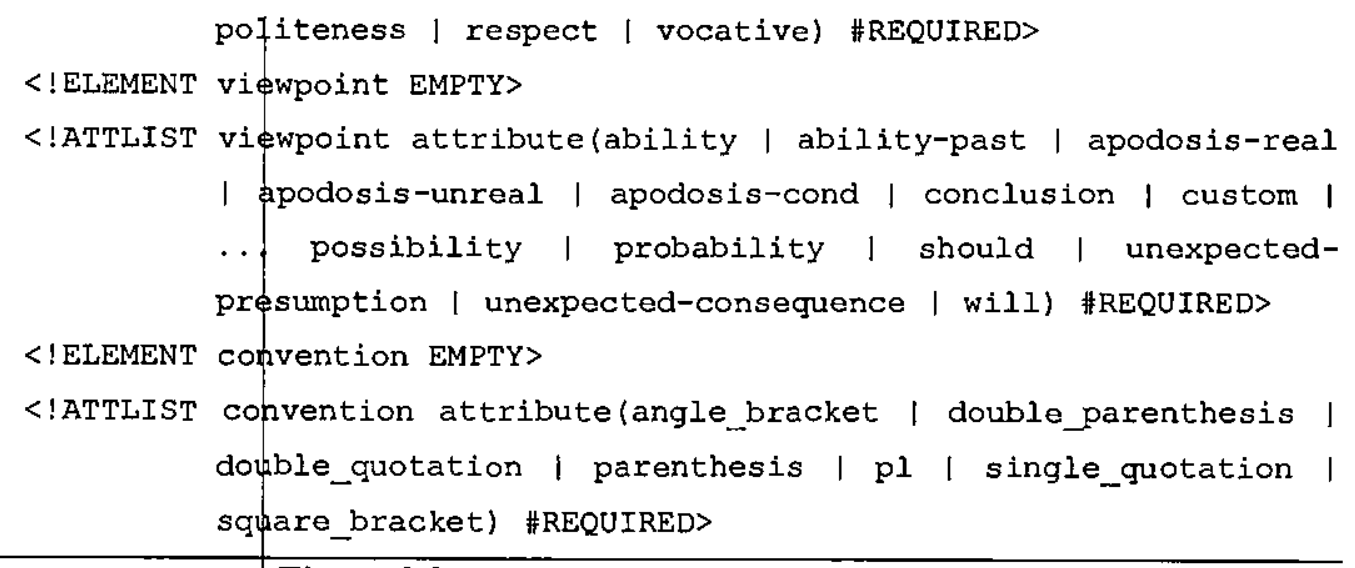

Figura 5.5 Sintaxe geral de um rótulo de atributo

Os rótulos de atributos estão agrupados em sete subgrupos, facilitando a escolha do atributo. A seguir, apresenta-se uma descrição deste grupo e os atributos envolvidos.

a) Tense, subgtupo que expressa tempo verbal. Estão agrupados os atributos que outorgam loçalização no tempo ao conceito. Temos três rótulos de atributo que estão envolvidos neste subgrupo:

- Past: refere-se ao evento que aconteceu no passado.

- Present: refere-se a um evento que está acontecendo.

- Future: refere-se ao evento que irá acontecer.

b) Aspect, subgrupo que se refere à noçāo de aspecto da língua inglesa. Está relacionado com o estado de um evento/objeto que forma parte da mensagem.

- Begin-soon: está relacionado com o evento que vai começar.

- Begin-just: está relacionado com o evento que recém começou.

- Progress: está relacionado com o evento que está em progressão.

- End-soon: está relacionado com o evento que está quase terminando.

- End-just: está relacionado com o evento que recém terminou.

- Complete: está relacionado com o evento já concluído.

- State: está relacionado com o estado final de um evento/objeto após a ocorrência de um outro evento.

- Repeat: está relacionado com a definição de um evento repetitivo, envolvendo o mesmo agente/objeto. 
c) Reference, subgrupo que indica se o conceito está descrevendo um objeto, ou um pequeno grupo, ou a todos. Os seguintes rótulos de atributos são usados para explicitar a referência de um objeto.

- Generic: descreve que o conceito é genérico.

- Def: descreve que o conceito já foi referido.

- Indef: descreve que o conceito não pertence a uma classe específica.

- Not: corresponde à negação.

- order: determina a ordem do conceito.

d) Focus, subghupo que permite a quem constrói a mensagem poder evidenciar ou enfatizar um conceito ou parte da mensagem. Desta forma, pode-se indicar na mensagem a importância do que se pretende descrever. Geralmente está relacionado com a estrutura da mensagem.

- Emphasis: enfatiza um conceito.

- Entry: descreve o conceito como o princípio ou ponto de início de uma mensagem. É indispensável em uma mensagem UCL.

- Qfogus: informa o conceito que recebe o foco na mensagem.

- Theme: informação temática.

- Title: aponta um conceito correspondente ao título, como forma sentencial.

e) Attitude, refere-se às atitudes ou emoções que um agente pode adotar, seja direta ou indiretamente. Isto inclui respeito, cortesia relacionado ao que se transfere na mensagem.

- Affilmative: afirma um evento.

- Confirmation: requer confirmação do evento.

- Exclamation: representa o sentimento de exclamação sobre algum evento.

- Imperative: declaração imperativa.

- Interrogative: declaração interrogativa sobre um evento.

- Invit tation: incentivar a fazer ou realizar algum evento.

- Poli teness: representa o sentimento de cortesia. 

- Respefct: reptesenta o sentimento de consideração ou respeito.

- Vocative: representação de expressões usuais.

Viewpoint, tefere-se a uma variedade de possibilidades para representar grau de crença, enfatizar alguma coisa, e estender alguma explicação sobre o assunto que se está tratando. Isto vai depender do estado em que se encontre o agente transmissor. Os seguintes tótulos de atributos são usados para esclarecer pontos de vista de informação.

- Abxlifty: representa a habilidade, ou capacidade de executar algo.

- Ability-past: representa alguma habilidade efetuada no passado.

- Apodosis-real: representa o apódose e refere-se a segunda parte de um periodo gramatical, em relação a primeira, de cujo sentido é complemento.

- Apod申sis-unreal: representa o apódose.

- Apodosis-cond: representa o apódose de forma condicional.

- Conclusion: representa uma conclusão de uma primeira parte da mensagem.

- Custom: ação habitual, e corresponde ao passado.

- Expectation: representa a expectativa sobre outros objetos/agentes.

- Grant: conceder permissão para executar algo.

- Granf-not: não conceder permissão para a execução de algo.

- Insis tence: insistência na execução de alguma ação.

- Intention: representa a intenção de fazer alguma ação no futuro.

- Inevi tabili ty: representa a suposição de que algum evento é inevitável.

- May: fepresenta a suposição de uma atual possibilidade.

- Obligation: obrigar a alguém a executar alguma ação.

- Obligation-not: proibir a alguém a executar alguma ação.

- Possibility: representa uma razoável possibilidade de que aconteça um evento.

- Probability: representa uma razoável probabilidade sobre algo.

- Should: representa o sentimento de imposição.

- Unexpected-presumption: pressuposição contrária ao que se esperava. 
- Unexplected-consequence: representa uma conseqüência contrária ao esperado.

- Will: representa o sentimento de querer executar algo.

g) Convention, este último subgrupo se refere à representação de símbolos convencionais.

- Angle_bracket: representa o uso dos símbolos $\langle>$.

- Double_parenthesis: representa o uso dos símbolos $(())$.

- Doubfe_quotation: representa o uso dos símbolos " ".

- Parenthesis: representa o uso dos símbolos ( ).

- P1: representa o plural.

- Single_quotation: representa o uso dos símbolos".

- Squafe_bracket: representa o uso dos símbolos [ ].

\subsection{Considerações finais}

Neste capítulo foi definida a linguagem de comunicação UCL. Ela pode ser situada, de acordo com a descrição apresentada no capítulo 3 , entre as linguagens de comunicação envolvendo agentes de software (ACL). Por UCL ser uma linguagem derivada do XML, sua integração com linguagens que suportam a comunicação entre agentes, como KQML e FIPA-ACL, derivadał do Lisp fica mais dificil (mas não impossível). Por outro lado, a sua integração com linguagens de suporte a comunicação, específicas para Internet, como a SOAP (Simple Object Access Protocol) (SOAP, 2000) derivada da XML, é muito facilitada. Essas linguagens, especialmente a SOAP, estão se tornando o padrão para comunicação de mensagens na Internet.

A notação utilizada para especificar a linguagem UCL foi definida em função da metalinguagem XML: foi usado um documento no formato DTD para definir sua sintaxe. $\mathrm{Na}$ especificação da linguagem UCL tentou-se manter o poder tepresentativo herdado da UNL na expressão de sentenças ao mesmo tempo que se adicionou a portabilidade e a compatibilidade com padrões da Internet da linguagem XML. 
A linguagem UCL é фompativel com a linguagem UNL, desta forma, no futuro, mensagens codificadas na linguagem UNL poderão ser representadas em UCL e vice-versa. Utilizandose a especificação da linguagem UCL apresentada neste capítulo, implementou-se um protótipo que transforma sentenças do inglês para UCL e de UCL para o inglês, que será descrito no próximo capítulo. 


\section{UM ENCONVERTER-DECONVERTER UCL}

\subsection{Considerações iniciais}

Neste capítulo é mostrada a implementação de um protótipo de um progtama EnconverterDeconverter. Esses termos, enconverter e deconverter, vieram do projeto da UNL (Uchida, 1999) e significam, respectivamente, um programa que converte sentenças de uma linguagem natural para uma interlíngua e um programa que converte de uma interlíngua para linguagem natural. No caso desse trabalho a interlíngua é a UCL e o protótipo trabalha com a língua inglesa como linguagem natural (ele também trabalha com o francês).

O detalhamento do desenvolvimento da linguagem está baseado na descrição da sua especificação e dos recursos apresentados nos capítulos anteriores. Também é mostrada uma arquitetura de um sistema que utilizaria a linguagem UCL.

\subsection{Gramática}

Para discutir a implementação do protótipo, setá necessário situar alguns conceitos manipulados pela implementação.

A linguagem UCL é especificada através de regras que descrevem a estrutura da mensagem. $O$ conjunto destas regras compõe a gramática da linguagem. O reconhecimento de uma mensagem UCL é feito pelo interpretador JAXP da Sun (Sun, 2001). A leitura de cada item, denominado "token", é feita pelo analisador léxico do JAXP.

A seguir, na Tabela 6.1, são mostradas as principais etiquetas que representam a estrutura de uma mensagem UCL, que contem informações sobre a sentença, conceitos (UWs) e relações. 
Tabela 6.1 Principais etiquetas para a construção de mensagens UCL

\begin{tabular}{|c|c|l|}
\hline Etiqueta & & \\
\hline$<$ sentence $>$ & Inicio & da mensagem \\
\hline$</$ sentence $>$ & Fim da menscrição \\
\hline$<$ uw $>$ & Inicio de um conceito/objeto. \\
\hline$</$ uw $>$ & Fim de um conceito/objeto. \\
\hline$<$ relation $>$ & Definição de uma relação envolvendo dois conceitos previannente definidos. \\
\hline$</$ relation $>$ & Fim de uma relação que envolve dois conceitos \\
\hline
\end{tabular}

Além das etiquetas mostradas acima, temos também: os rótulos de atributo e rótulos de relação que foram especificados no capítulo 5. O Apêndice B mostra a gramática completa da linguagem UCL definida em um documento DTD.

\subsection{Implementando o protótipo}

O protótipo é implementado seguindo as características mostradas no capítulo 5. Elas podem ser resumidas em: a) (permitir que a linguagem seja de fácil integração à rede Internet; b) ser de fácil utilização; c) permitir sua escalabilidade e estensibilidade. A estrutura das mensagens UCL está baseada no DTD definida e descrita no capítulo 5. Para validar os documentos $\mathrm{XML}$ com o DTD, precisou-se de um interpretador de documentos XML, no caso o JAXP que usa a API DOM.

Para a representação semântica da linguagem, precisa-se de uma ontologia que represente os conceitos envolvidos na mensagem. Neste ponto, adotou-se a ontologia usada no programa Thougbtrreasure. Ela ihclui a utilização de bibliotecas que permitem manipular os conceitos da ontologia, realizar consultas na rede de conceitos, e analisar a hierarquia. 
Além disso, implementou-se em Java uma API UCL que permite gerar e manipular as mensagens UCL. Na Figura 6.1 são mostradas as classes que foram utilizadas e a interface que foi implementada|no protótipo.

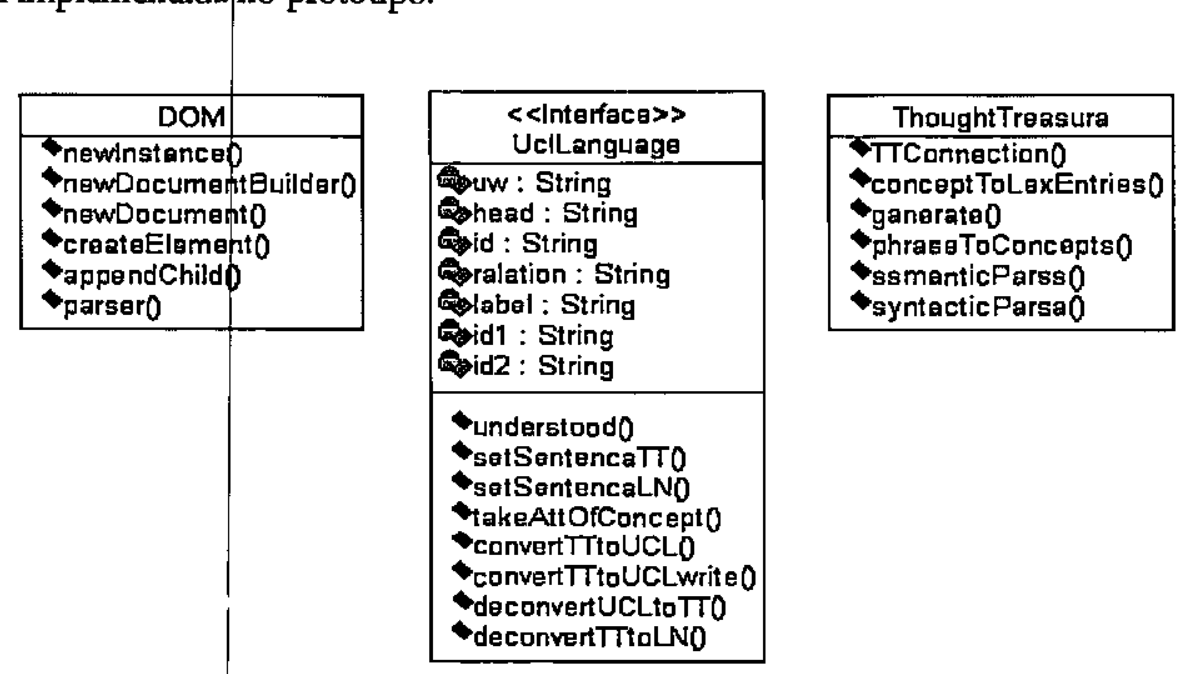

Figura 6.1 Classes e interface do protótipo.

Na Figura 6.2 é mostrado o diagrama de classes da implementação do protótipo, este diagrama mostra quais são as relações entre a Interface UclLanguage com as Classes.

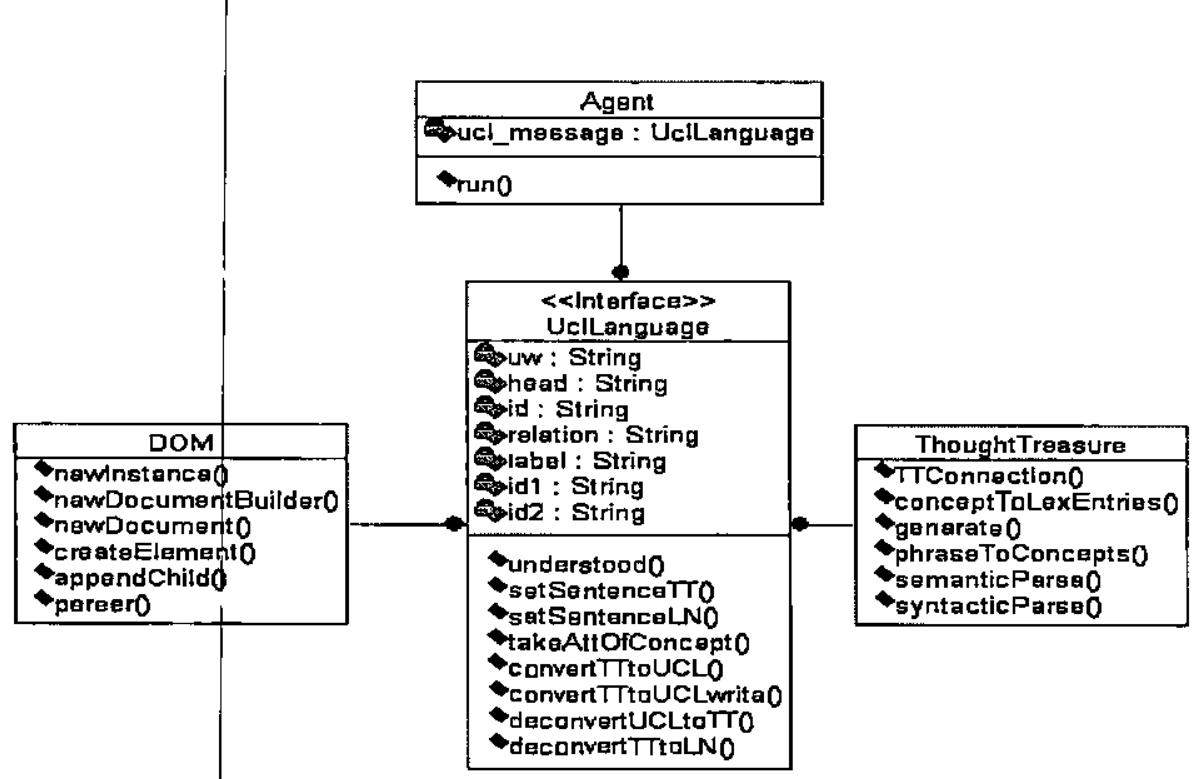

Figura 6.2 Diagrama de Classes. 


\subsubsection{0 enconverter}

O processo de codificação, feito pelo enconverter, segue a seqüuência de eventos mostrada no diagrama da Figura 6.3. Nele o protótipo faz uso da interface UclLanguage para gerar mensagens UCL. O processo começa quando o enconverter chama o método understood da interface $U_{c l \text { Language, }}$ desta forma se interpreta a sentença em linguagem natural e são retornadas várias interpretações desta sentença (dependendo de como a sentença foi entendidas pelo progatama Thought Treasure). Na continuação, o usuário escolhe a interpretação mais adequada. A partir desta interpretação escolhida é realizado um processo de codificação para a linguagem UCL, resultando numa mensagem UCL. Esta mensagem pode ser manipulada e/ou enviada a outro agente.

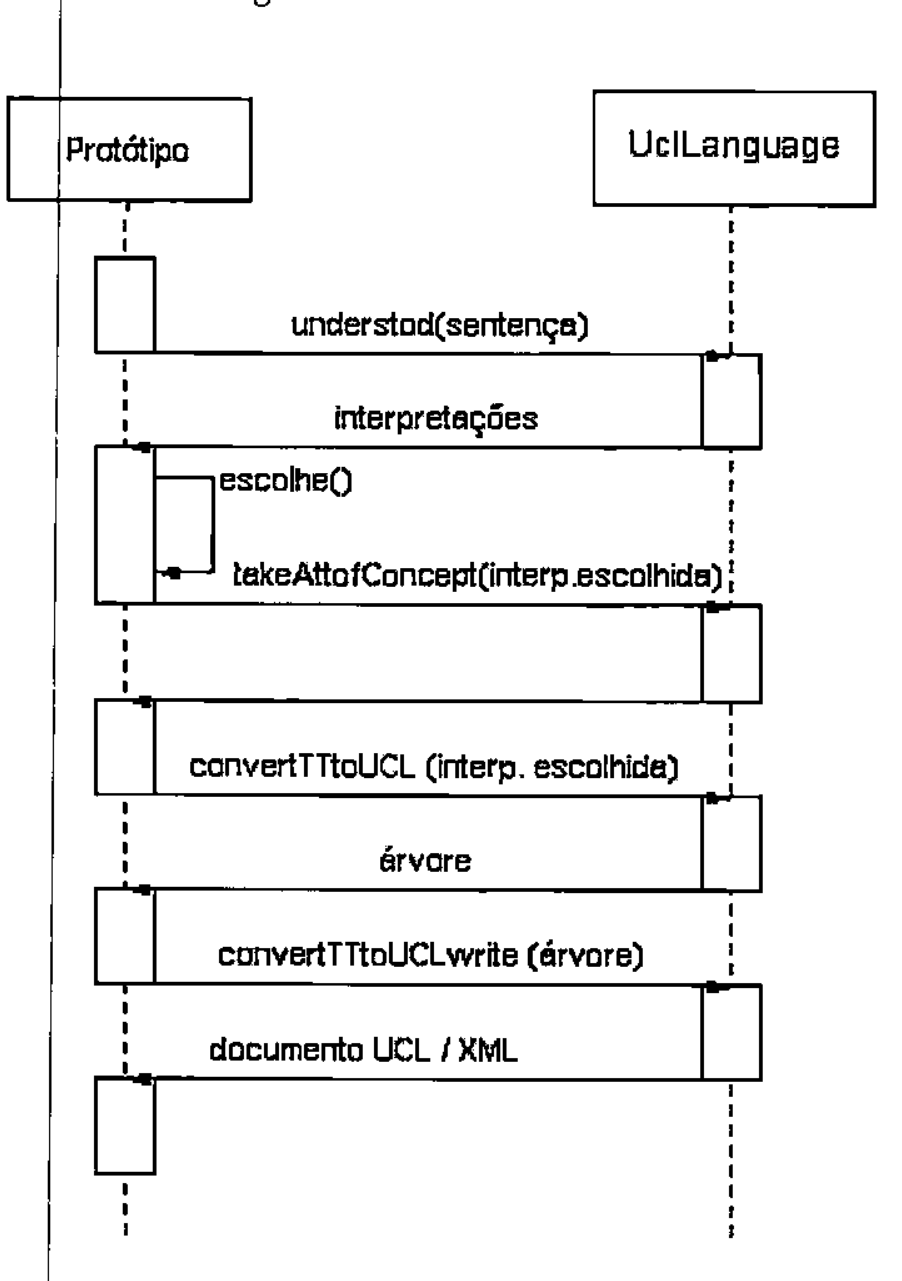

Figura 6.3 Diagrama de seqüência de eventos.

Segue uma descrição mais detalhada do processo de geração das mensagens UCL e uma descrição do funcionamento de cada método no processo. 


\section{Intexpretando uma sentença em linguagem natural}

O método Understood f́ chamado para realizar a interpretação de uma sentença em linguagem natural, e tetorna uma lista de sentenças que expressam a mensagem inicial. Como resultado da aplicação deste méłodo, pode-se obter dois tipos de resultados (Figura 6.4). No primeiro caso, o resultado podł ser nulo, significando que alguma entrada léxica não está cadastrada na ontologia e, por isso, não foi conseguida nenhuma representação conceitual. No segundo caso, o resultado pode ser uma lista de alternativas, significando que a sentença que se deu como entrada têm vátias representações semânticas (ou várias representações que podem ser entendidas). Neste último caso o sistema não pode optar por uma delas, pois isso depende muito do contexto erp que se trabalha. Neste caso, deixa-se para o usuário a escolha de qual das interpretações é a mais apropriada.

Para poder avaliar sintaticamente e semanticamente a sentença, que está em linguagem natural, são criadas internamente duas estruturas. A primeira tefere-se a uma árvore de nós representando a avaliação sintática e a segunda é outra árvore de nós representando a avaliação semântica.

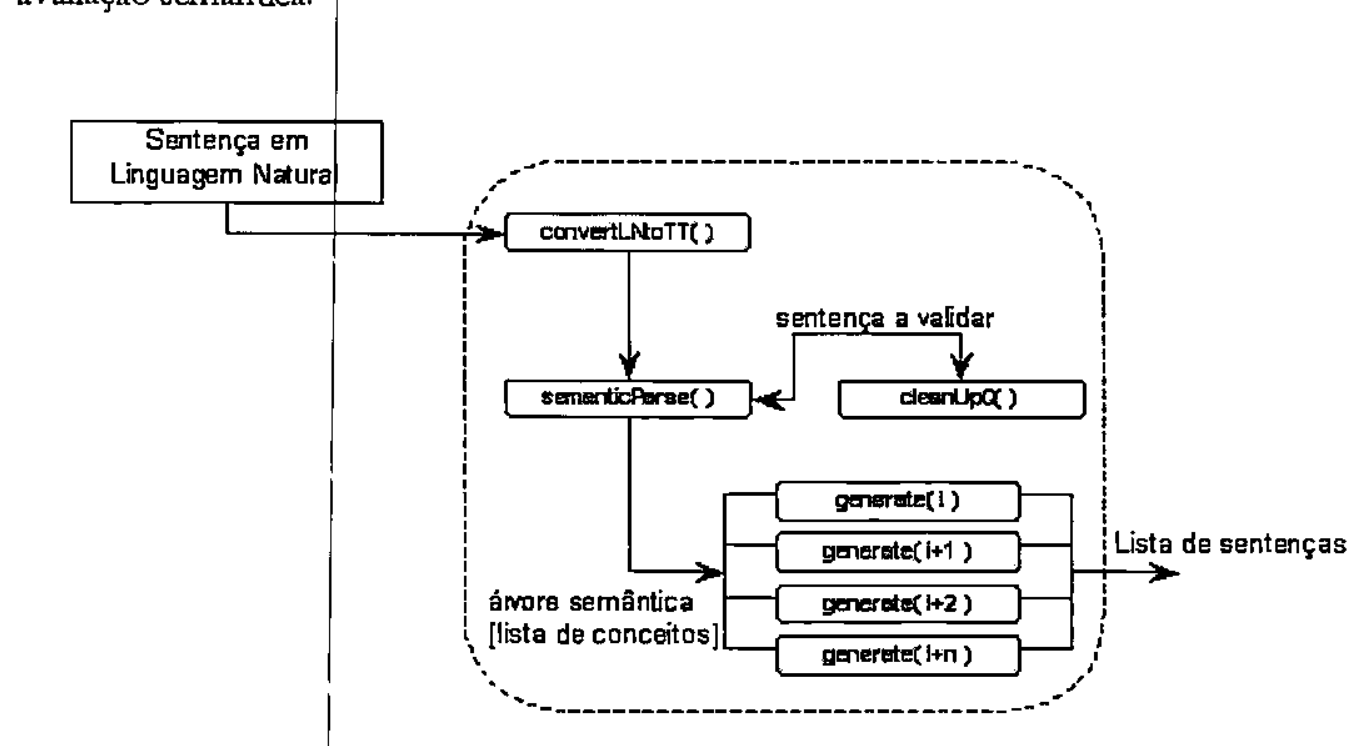

Figura 6.4 Interpretando uma sentença em linguagem natural

\section{Cadastrar a lista de conceitos}

Este método (setSentenceTT) cadastra a lista de conceitos dentro do enconverter. Esta lista de conceitos foi obtida do método understood apresentado anteriormente.

Obter os atributos de cada conceito 
Este método (takeAtt) fConcept) procura todos os atributos gramaticais das entradas léxicas que pertencem aos cohceitos que foram cadastrados no enconverter. Estes atributos gramaticais são posteriormente inferidos em cada conceito da mensagem UCL. Em conseqüência, podese descrever com maior precisão o significado de cada conceito.

Considerando a árvore semântica, que contém os conceitos envolvidos na mensagem, extraise cada conceito pała posteriormente procurar na ontologia as entradas léxicas e seus atributos gramaticais.

\section{Transformar a lista de conceitos na mensagem $U C L$}

Este método (Converf TTtoUCL) cria a mensagem UCL baseado nos conceitos anteriormente cadastrados no enconterter. Este método utiliza a API DOM do JAXP para criar a árvore de nós que representará posteriormente a mensagem UCL. A construção desta árvore baseia-se na gramática $d_{a}$ linguagem UCL especificada no capítulo 5. A Figura 6.5 mostra que este processo se realiza em duas etapas.

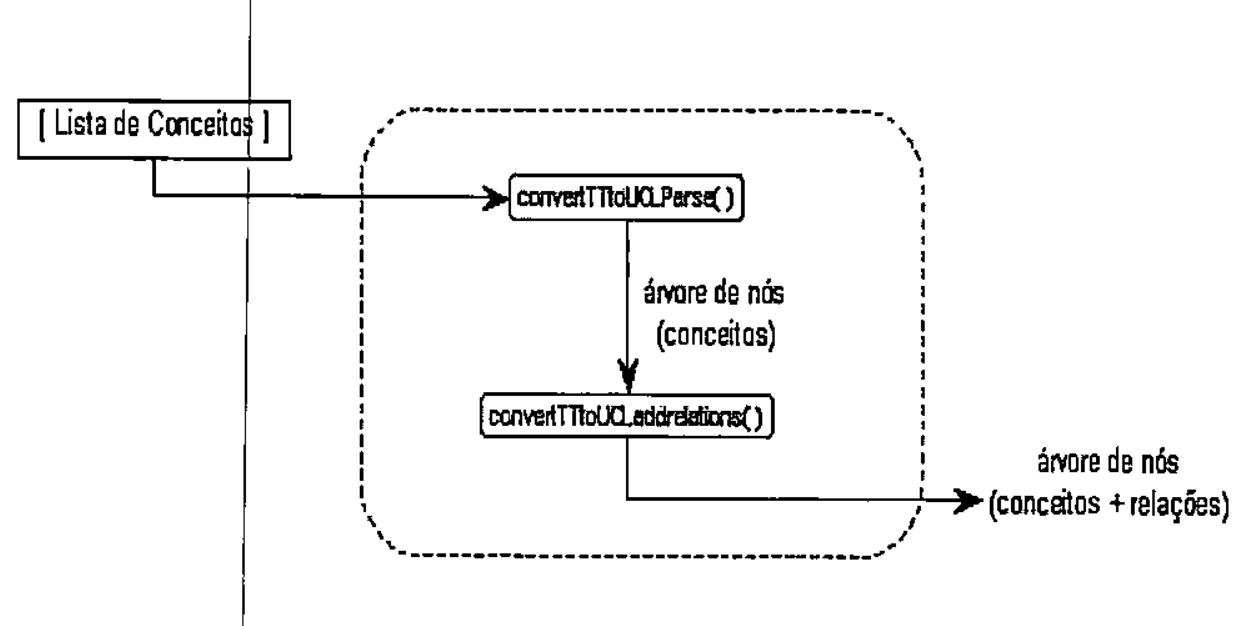

Figura 6.5 Transforma a lista de conceitos na mensagem UCL

Na primeira etapa são gerados os conceitos na forma de UWs. Além disso, é inserido um identificador único para cada conceito. Como é mostrado na Figura 6.6, a entrada inicial é a lista de conceitos, a partir dela se verifica a existência de cada conceito na ontologia e se obtém o conceito pai de cada um (desta forma se descobre a que hierarquia o conceito pertence). É usada a tag icl para indicar o conceito pai de cada um.

$\mathrm{Na}$ segunda etapa, as relações existentes entre os conceitos são determinadas e elas são explicitadas através da tag relation. Este processo dá forma e estrutura à mensagem. Para 
explicitar estas relaçõłs, são utilizados os identificadores definidos na primeira etapa. Cada conceito definido anteriormente é referenciado.

O resultado da primeira etapa mais o resultado da segunda etapa formam uma única árvore de nós que representa a mensagem UCL.

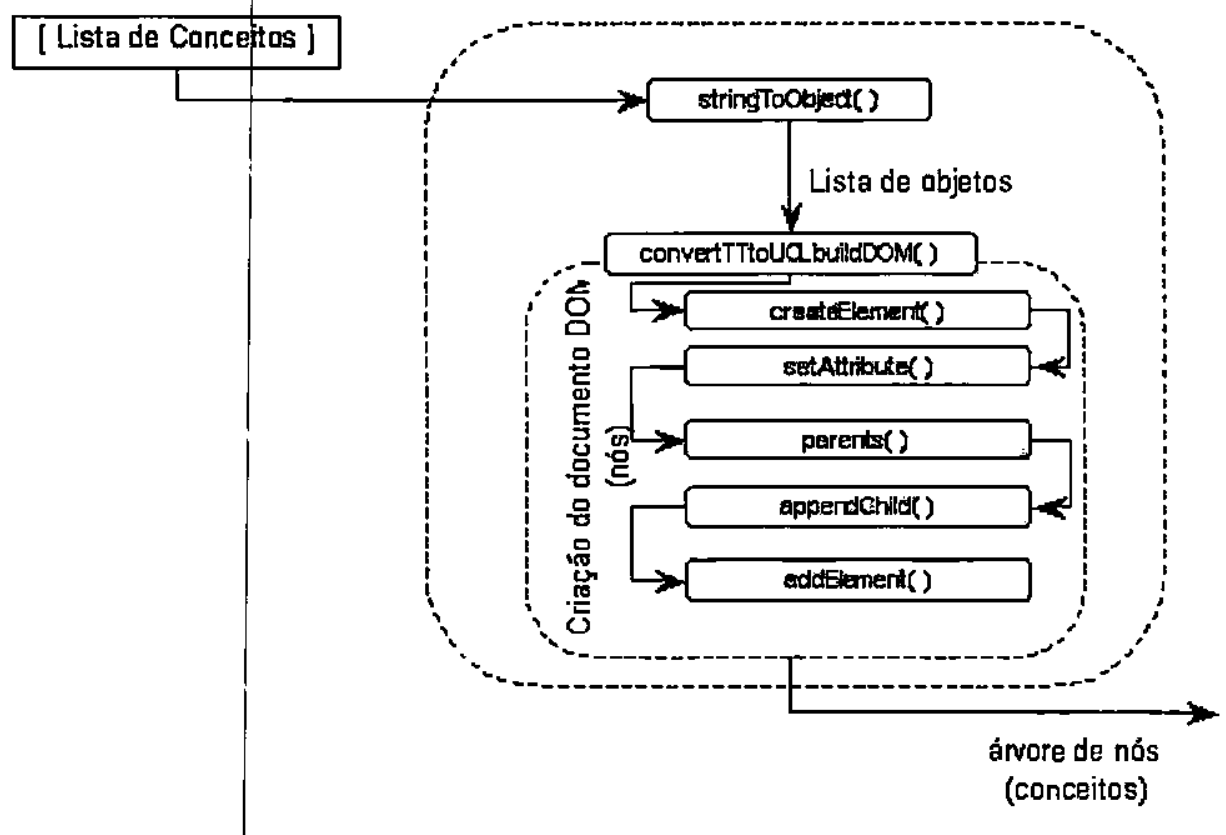

Figura 6.6 Criação de árvore de nós de um documento UCL.

Criar fisicamente a mensagem UCL como documento XML

Este método (convert f TtoUCLurite) escreve fisicamente a mensagem UCL em um arquivo que pode ser enviado a outro agente. Inicialmente, tem-se a estrutura da mensagem em uma árvore de nós criadá pela API DOM, onde estão embutidos os conceitos da mensagem e suas relações. Para criar o documento XML, a partir desta árvore, chama-se o método urite da API DOM do JAXP, obtendo-se desta forma um documento contendo a mensagem na linguagem UCL.

\subsubsection{O deconverter}

O processo decodifickação é iniciado com a recepção de uma mensagem codificada em UCL, para posteriormente ser transformada em uma sentença em linguagem natural equivalente.

Transformar a mehsagem UCL na lista de conceitos 
Este método (deconverfUCL toTT), como mostrado na Figura 6.7, decodifica a mensagem UCL transformando- $a$ em uma lista de conceitos. Para se obter esta lista de conceitos, primeiro precisa-se exprair da mensagem UCL as relações existentes, estas relações são as que indicam a seqüência e prioridade dos conceitos. Após a obtenção destas relações, se constrói a lista de conceitos percorrendo o conjunto de relações. Neste processo, utiliza-se o identificador (atributo id) de cada conceito para obter seus nomes.

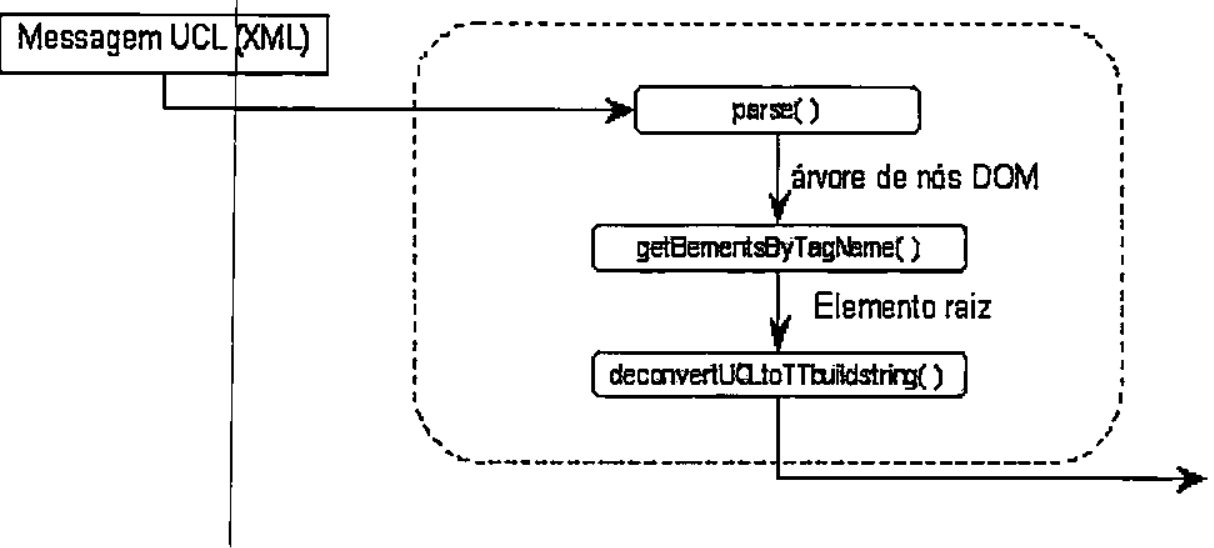

Figuta 6.7 Transforma a mensagem UCL na lista de conceitos

Transformar a lista de conceitos em uma sentença em linguagem natural

Como pode ser obsqrvado na Figura 6.8, este método (deconverterTTtoLN) transforma a lista de conceitos em uma sentença em linguagem natural, que representa a sentença UCL original. A sentença em linguagem natural, obtida deste método, pode ser em Inglês ou em francês, isto porque q ontologia utilizada contém entradas léxicas para as duas línguas.

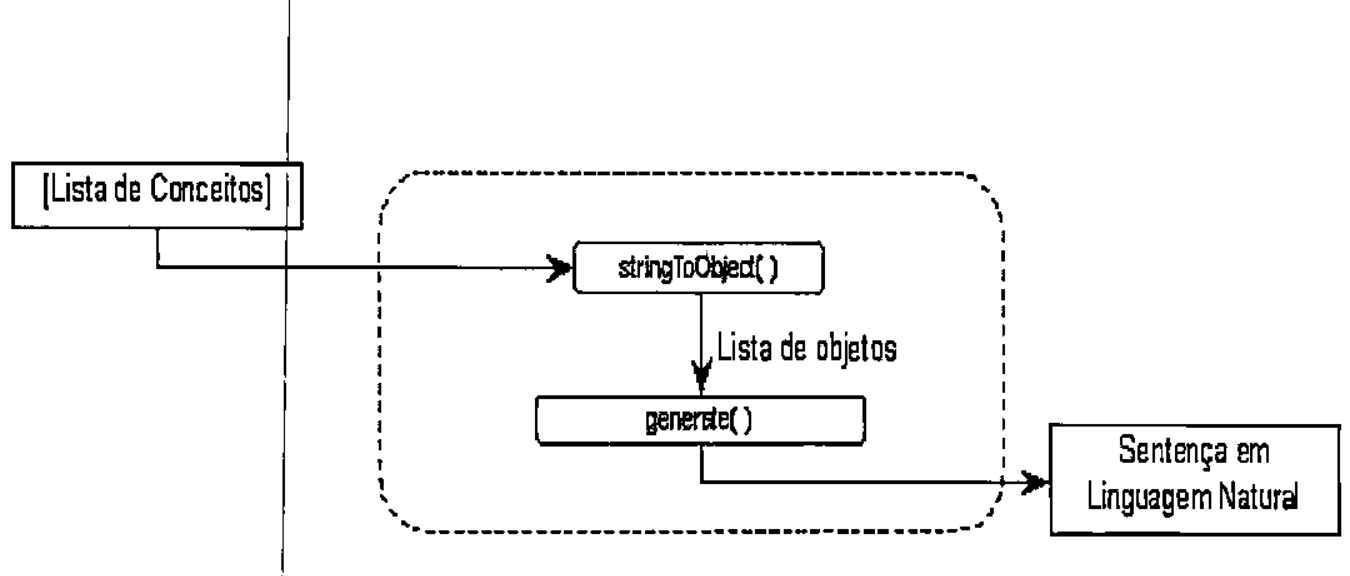

Figura 6.8 T fansformar a lista de conceitos numa sentença em linguagem natural 


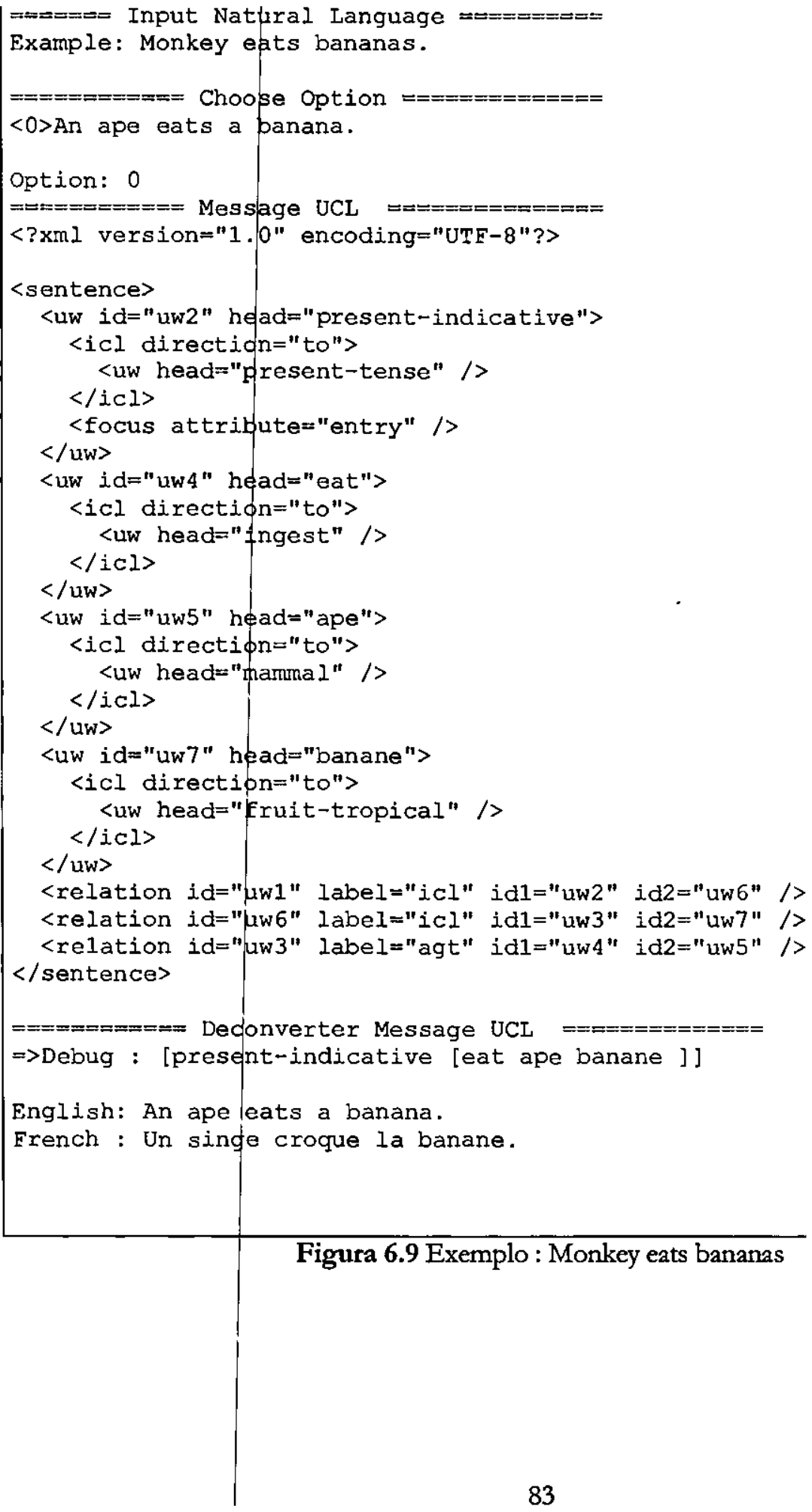

Figura 6.9 Exemplo : Monkey eats bananas 


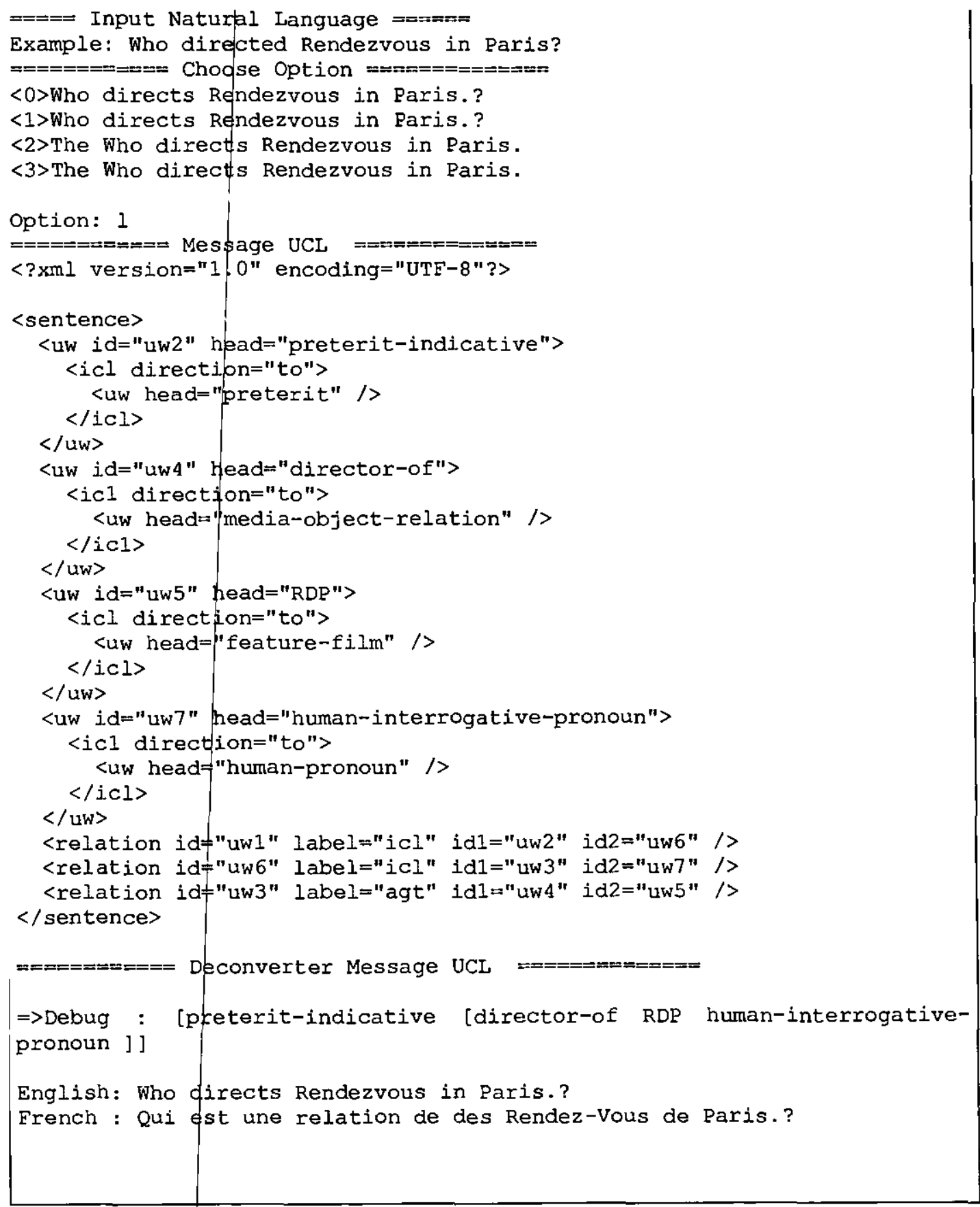

Figura 6.10 Exemplo: Who directed Rendezvous in Paris? 


\subsection{Arquitetura de um sistema de comunicação em UCL}

A utilização da linguagem UCL, entre dois agentes de software, pode ser implementada através da arquitetura mostrada na Figura 6.9.

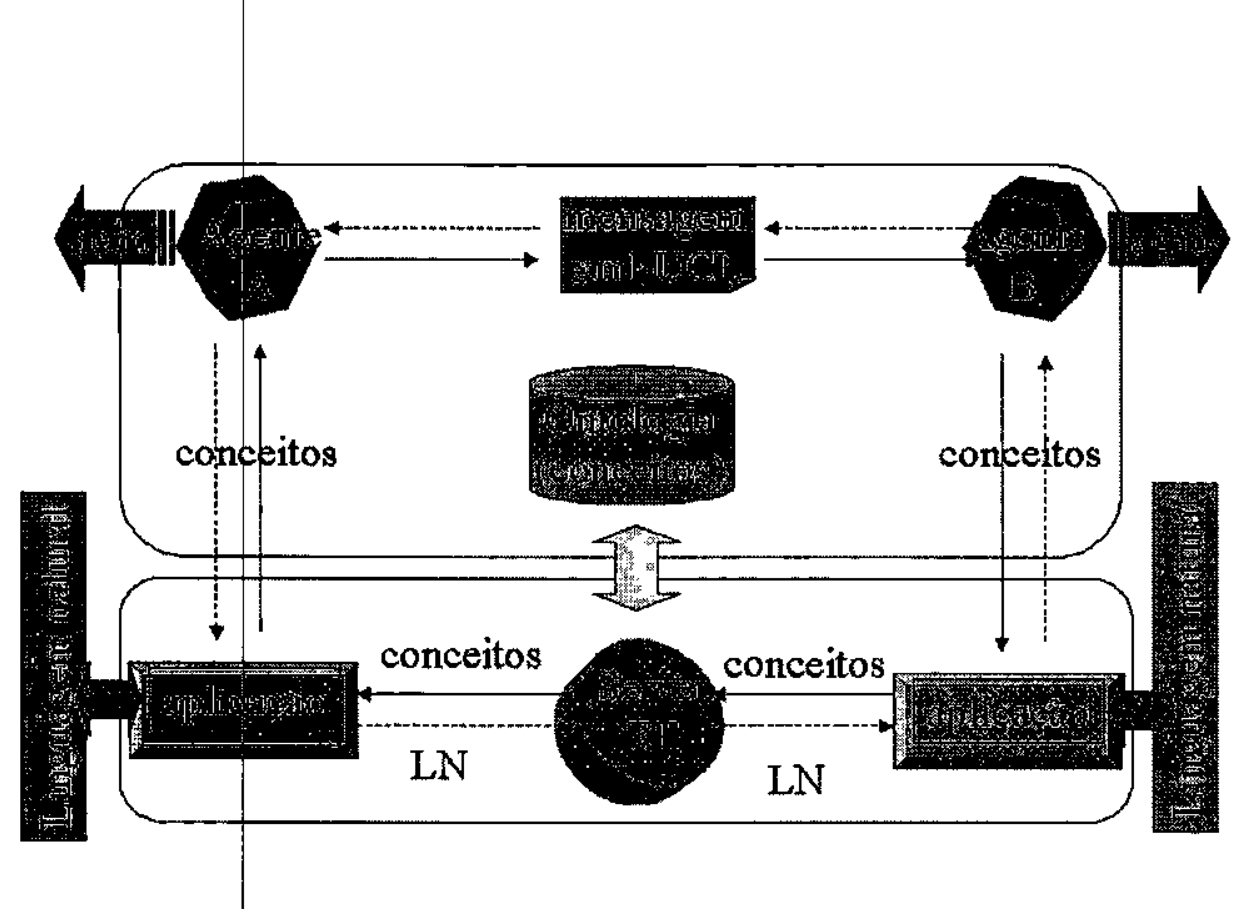

Figura 6.11 Arquitetura de um sistema que utiliza a linguagem UCL

No caso em que o agente A precisa se comunicar com o agente $B$, existem as seguintes possibilidades de comunicação:

- O usuário quer se comunicar com o Agente A: O fluxo inicia-se quando o usuátio cria, em lingagem natural, uma mensagem que vai ser dirigida ao Agente A. Esta mensagem é a entrada para o enconverter (dentro da interface de usuário), que inicia a comunicação com o servidor TT (ThoughtTreasure) para efetivar o parser da sentença. A seguir, obtén-se do servidor TT a lista de conceitos da sentença. Com esta lista de conceitos, é construída a mensagem UCL, para finalmente ser enviada ao Agente A. O Agente A, em função da mensagem, pode efetuar alguma ação.

- O usuário quer se comunicar com o Agente B por meio do Agente A: De forma similar ao caso anterior, o fluxo inicia-se quando o usuátio cria, em linguagem natural, uma mensagem que vai ser dirigida ao Agente B. A Interface realiza a comunicação com o servidor TT, para obter a lista de conceitos, e posteriormente gera a 
mensagem UCL que será enviada ao Agente A. Este envia a mensagem ao Agente B que o processa.

- O usuário quer se comunicar com outro usuário: Neste caso, a entrada para a aplicação é uma sentença em linguagem natural sobre a qual o enconverter realiza o processo de codificação para UCL. Desta forma; o Agente A envia a mensagem codificada ao Agente $\mathrm{B}$, este último realiza a comunicação com o servidor TT e por meio do deconverter gera a sentença em linguagem natural para o segundo usuário.

- O Agente A se quer comunicar com o Agente B: Neste caso, o Agente A, que é proativo, inicia uma requisição ou consulta ao Agente B por meio de mensagens UCL. Não é preciso nenhuma codificação ou decodificação para linguagem natural, pois os agentes se comunicam com mensagens baseadas em UCL.

\subsection{Considerações Finais}

Este capítulo mostrop a implementação de um programa enconverter-deconverter usando UCL. A implementação consjderou as características requeridas para ser de fácil integração na rede Internet, ser legivel, também como permitir sua escalabilidade e estensibilidade.

Foi feito uma deschição da API UCL implementada em Java que auxilia a geração de mensagens UCL. Além disso, foi considerada uma arquitetura de sistema utilizando a linguagem UCL.

Ficou demonstrado que a linguagem UCL atende os requisitos exigidos para atuar como interlíngua e como linguagem de comunicação entre agentes de software. O protótipo de enconverter-deconverter, feito em Java e usando a versão de servidor do programa ThoughtTreasure, foi usado para testar a viabilidade da UCL como linguagem de comunicação. 


\section{CONCLUSÃO}

\subsection{Considerações iniciais}

Neste capítulo é feita a sintese dos resultados deste trabalho. Ressaltam-se algumas decisões de projeto, contribuições e sugestões de futuras pesquisas que podem vir a ser desenvolvidas a partir deste trabalho.

\subsection{Decisões de Projeto}

Neste item são feitas as descrições de algumas das decisões de projeto assumidas durante este trabalho, de forma a ressaltar aquelas já descritas no texto e complementar outras que não foram anteriormente citadas.

Durante a definição da linguagem UCL (Universal Communication Language) procurou-se abranger todos os conceitos teóricos da linguagem modelo, que neste caso foi a UNL (Universal Networking Language) (Uchida, 1999). Desta forma se tentou preservar o poder representativo desta linguagem.

Os vários requisitos de uma linguagem para comunicação entre agentes, tais como: uma linguagem com ênfase na semântica da mensagem, facilidade de utilização, e compatibilidade com as linguagens usadas na Internet, dentre outros, levaram a optar por recursos como a linguagem XML, o uso de ontologias e a base teórica derivada da UNL.

Sendo a linguagem UCL definida para ser utilizada na comunicação entre agentes, foi importante ressaltar como as mensagens iriam representar conceitos do mundo real, neste caso optou-se por ut lizar ontologias como meio de representação. Existiam algumas bases de dados ontológicas que poderiam ser usadas, tais como WordNet (Miller, 1995b), Cyc (Lenat, 1995), ThougbtTreasure (TT) (Mueller, 1998). Algumas destas bases ontológicas eram 
proprietárias, o que dificultava a utilização das mesmas, em outras não existia uma forma clara de acessar os dados (por exemplo através de uma API). Neste sentido a única que cumpria os requisitos de disponibilidade (não proprietária) e oferecia uma API para acesso à base de dados ontológica foi a base do programa ThoughtTreasure.

Uma outra razão para a utilização da base ontológica do ThoughtTreasure, foi porque o programa continho, juntamente com os conceitos ontológicos, vários atributos para representar linguagem natural que pode ser processada através da sua API TT em Java. Desta forma foi possível não só a especificação da linguagem proposta (UCL), como a escrita de um programa enconverter-deconverter para sentenças em linguagem natural (em inglês e francês).

\subsection{Contribuições}

As pesquisas em linguagens de comunicação entre agentes vêm acompanhando a evolução dos sistemas multi-agentes, na medida que permitem aos agentes comunicar e cooperar entre si para resolver um płoblema.

Em tal sentido, este trabalho contribui com a especificação de uma linguagem, a UCL, que considera a importância da semântica nas mensagens a serem representadas. Esta linguagem facilita a representaçăo de sentenças (mensagens) em linguagem natural, utilizando ontologias para reduzir confusões conceituais e terminológicas que por ventura existirem na construção da sentença. Além disso, a utilização de ontologias na linguagem auxilia na interoperabilidade entre diferentes aplicą̧ões que trocam mensagens. A UCL é uma concorrente direta da UNL, tendo as vantagens de:

1. Ser um software aberto, usando a GNU Public License.

2. Ser baseada numa linguagem padrão, a XML, já amplamente difundida na Internet, o que facilita sua integração em browsers (que já trabalham com XML ou HTML).

3. Ter como alvo não só o papel de interlíngua, mas também o de linguagem de comunicação e programação (Scripting) de agentes de software.

O protótipo de enconverter-deconverter, descrito no capítulo 6 , serve como ferramenta para experimentação e teste da proposta de linguagern apresentada. Esse protótipo usou 1 
ferramentas e prograpnas abertos, estando disponível para uso de todos sob a GPL (GNU Public License) para futuros aprimoramentos.

\subsection{Sugestões para Trabalhos Futuros}

Neste item apresentam-se sugestões de outros estudos que podem ser motivados a partir desta pesquisa.

Uma extensão deste trabalho é implementar um interpretador da linguagem UCL para agentes de software. Desta forma a UCL poderá operar como uma linguagem de programação (scripting), permitindo aos agentes de software executar as semânticas das ações efetuando algum tipo de tarefa. Apesar da UCL ter sido especificada também para esse tipo de aplicação, o protótipo implementado não testou esta faceta da linguagem, deixando-a para trabalhos futuros dentro do grupo.

O protótipo do enconverter-deconverter pode ser melhorado para se tornar uma fertamenta para comunicação entre pessoas de línguas diferentes. Reusando material do projeto UNL da UNU (United Nations University), a medida que este se tome disponível publicamente, ou partindo para soluçposes próprias, baseadas ou não no ThoughtTreasure, no processo de desenvolvimento nonmal de um software aberto.

\subsection{Considerações Finais}

O objetivo deste trabalho foi a especificação de uma nova ACL, a Universal Communication Language (UCL), que se preocupa com a descrição da estrutura das mensagens, com o modelo semântico e com suporte a protocolos para interação entre agentes (de software ou humanos) na Internet.

Este capítulo apresentou as conclusões deste trabalho, bem como suas contribuições para a comunidade e sugestões para a sua continuação.

A principal contribuyção deste trabalho foi a especificação da UCL e a demonstração de seu funcionamento através de um protótipo de enconverter-deconverter. 


\section{APÊNDICE A - DESCRIÇÃO DA LINGUAGEM UNIVERSAL NETWORKING LANGUAGE (UNL) (UCHIDA, 1999)}

Notação utilizada para descrever a sintaxe da UNL:

\begin{tabular}{|c|c|}
\hline $\begin{array}{l}> \\
=\end{array}$ & $\begin{array}{l}\text { simbolos não terminais / variáveis } \\
\text { cadeia de caracteres } \\
\text {... é definido como ... } \\
\text { disjunção, "ou". } \\
\text { elemento opcional } \\
\text { elemento alternativo } \\
\text { repete-se mais de zero vezes. }\end{array}$ \\
\hline
\end{tabular}

Estrutura Interna de relações binárias

<Binary relation> : : = <Relational Label> [":"<Compound UW-ID>] " $\{$ " $[<U W 1>$ |": "<Compound UW-IDI $>$ "," \{<UW2>|": "<Compound UW-ID2>\} ")"

Formato de UNL

A estrutura de um documento UNL é expresso usando as seguintes etiquetas:

[D] Início do documento

[/D] Fim do documento

[P] Inicio do parágrafo

[/P] Fin do parágrafo

[S] Inicio da sentença

[/S] Fim da sentença

Um documento UNL é construído da seguinte forma:

[D] Início do documento

[P] Início do parágrafo

[S] Início da sentença

... expressão UNL

[/S] Fim da sentença

... Repetiçāo de [S] ... [/S]

[/P] Fim do parágrafo 
... Repetição de [P] ... [/P]

[/D] Fim do documento

... Repetição de [D] ... [/D]

Uma expressão é identificada com as seguintes etiquetas:

\{unl\} Inicio da expressão UNL

$\{/$ unl $\}$ Fim da expressão UNL

Em uma expressão UNL existem três tipos de informação como, relações binárias, Uws, relações binárias codificadas. $\mathrm{Na}$ continuação, mostra-se as etiquetas que são usadas pata diferenciar esta inforrhação:

A sintaxe das relações binárias, Uws e relações binárias codificadas são as seguintes:

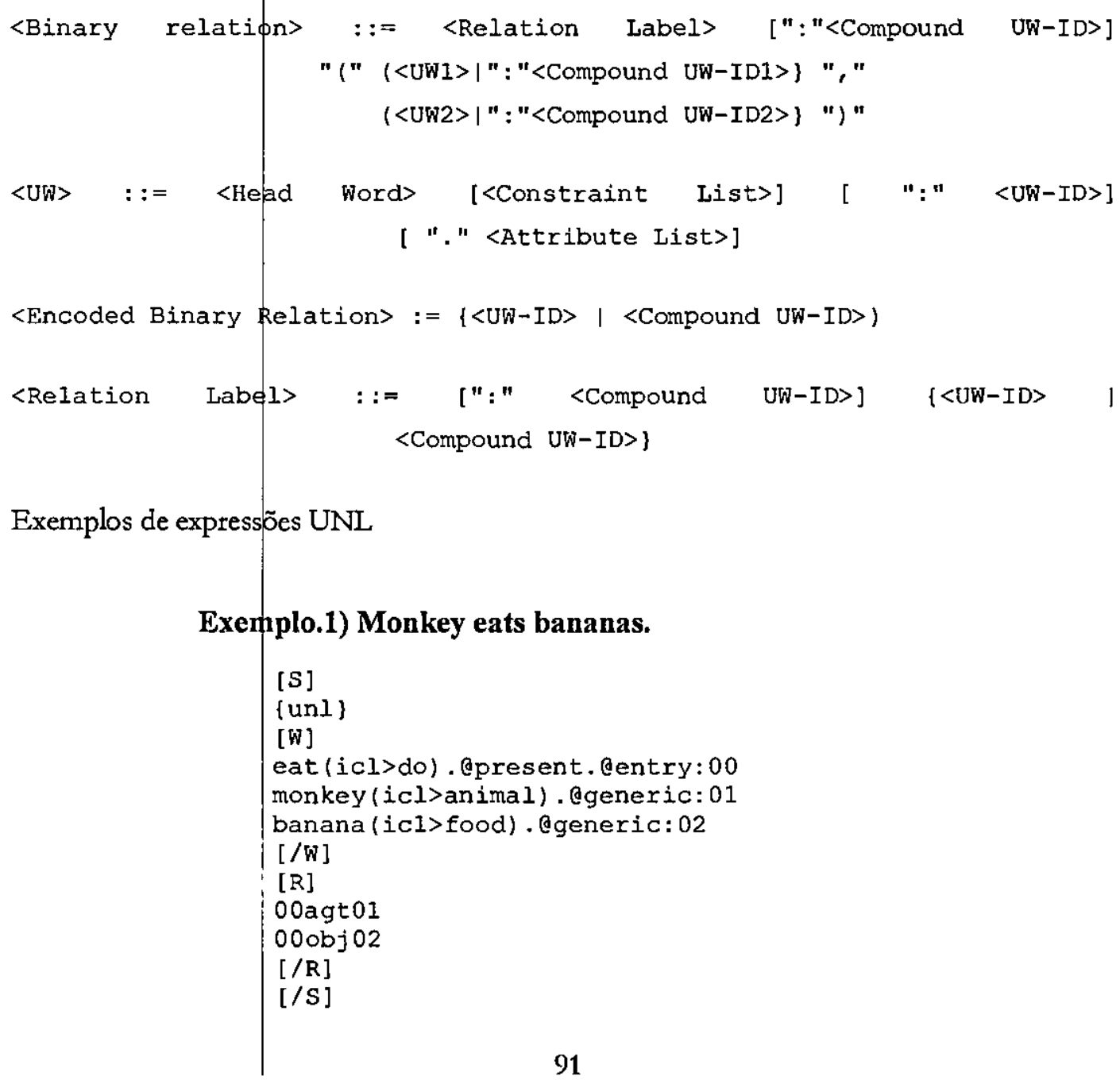

Exemplos de expressões UNL

Exemplo.1) Monkey eats bananas.

[S]

\{unl\}

[W]

eat (icl>do). (epresent. dentry:00

monkey (icl>animal). Ogeneric: 01

banana (icl>food). egeneric : 02

[/W]

[R]

00agt01

00 obj 02

[/R]

$[/ \mathrm{S}]$ 


\section{Exemplo.2) UNL is a common language that would be used for network communications.}

$$
\begin{aligned}
& \text { [S] } \\
& \text { \{ unl }\} \\
& {[W]}
\end{aligned}
$$

language (icl>abstract thing). epresent. @entry:00

UNL (icl>language). @topic: 01

common (aoj>thing) : 02

use (icl>do). Apresent: 03

language (icl>abstract thing). @present. @entry:04

communication (icl>action). epl:05

network (icl>thing): 06

[/W]

\section{Universal Words (UWs)}

Uma UW (Universal Word) representa um conceito simples ou um conceito composto. Os simples são conceitos unitátios chamados de Uws (Universal Words). Na continuação se mostra a sintaxe de una UW.

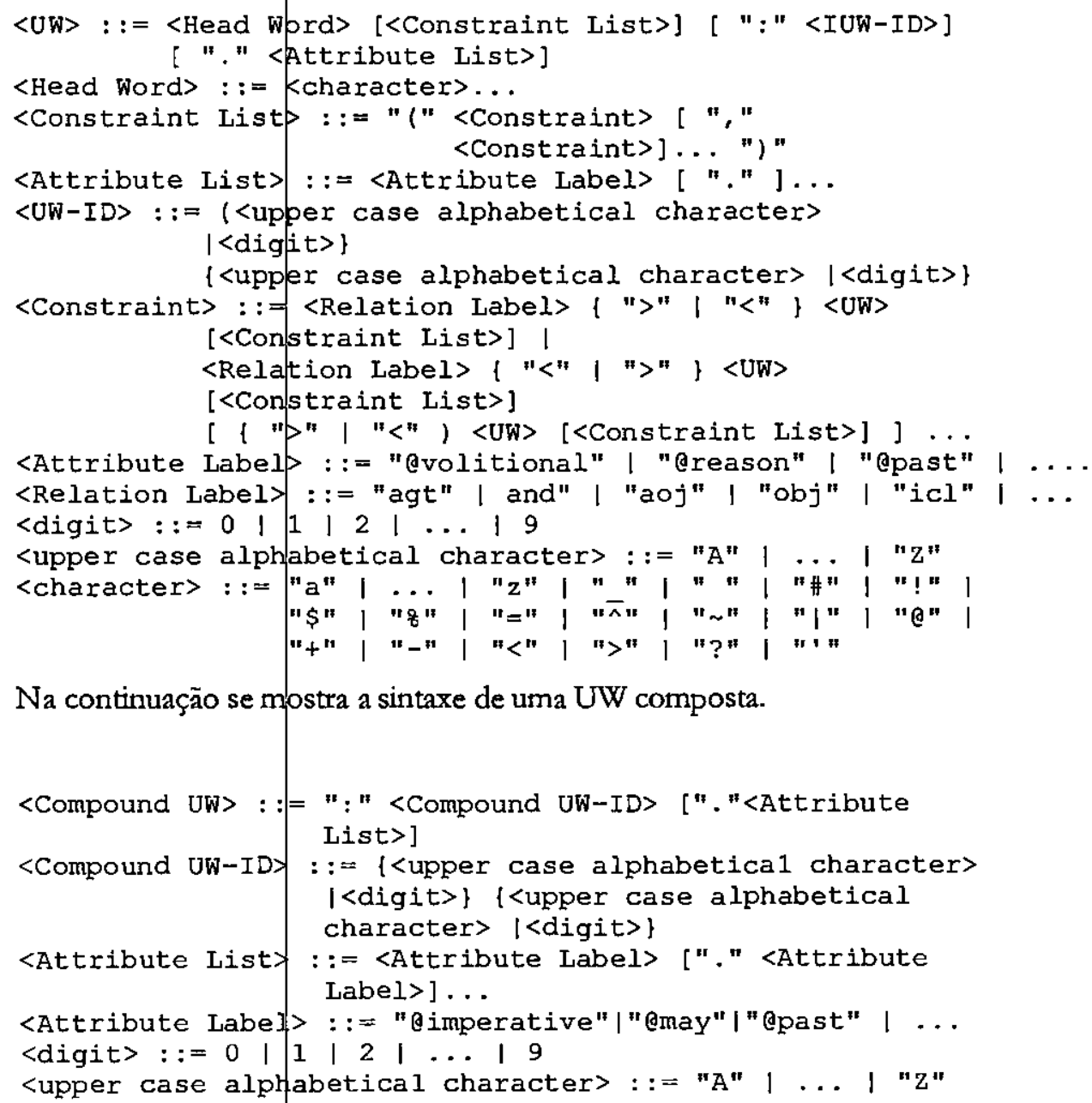




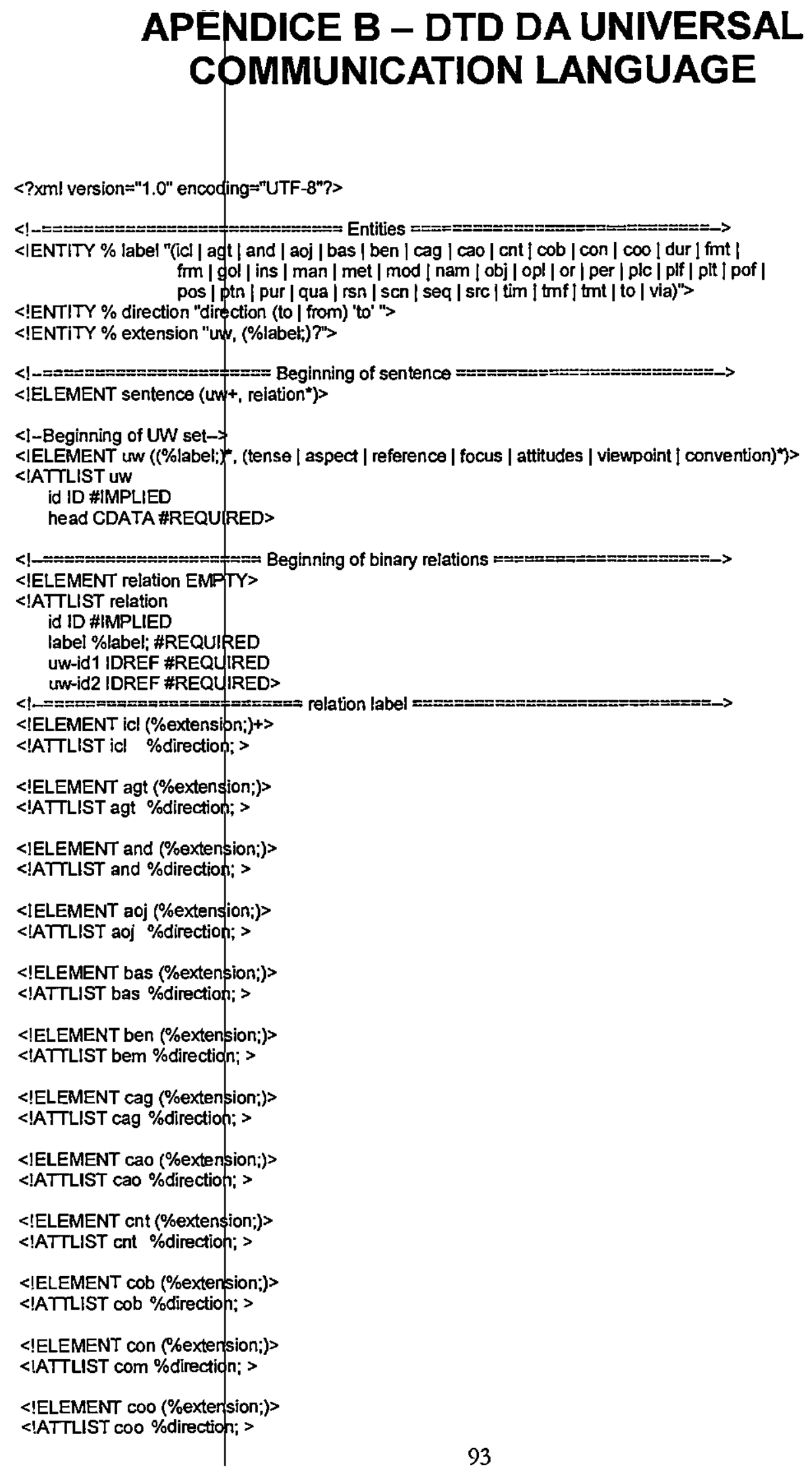




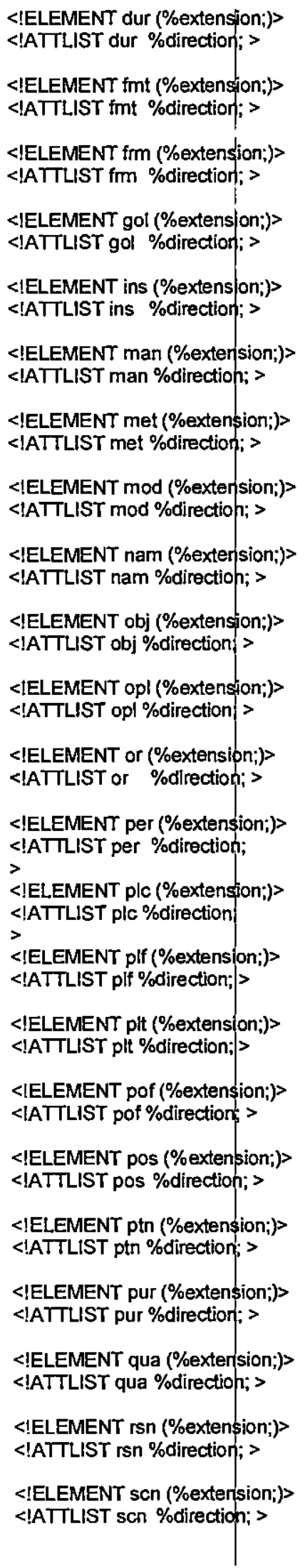

<!ELEMENT fimt (\%extension;)> <IATTLIST fimt \%direction; >

<IELEMENT frm (\%extension;)> <IATTLIST fm \%direction; >

<IELEMENT gol (\%extension;)> <!ATTLIST gol \%direction; >

<LELEMENT ins (\%extension;)> <!ATTLIST ins \%direction; >

<!ELEMENT man (\%extersion;)> <IATTLIST man \%direction; >

<LELEMENT met (\%extension;)> $<$ IATTLIST met \%direction; >

<!ELEMENT mod (\%extersion;)> $<$ IATTLIST mod \%direction; >

<!ELEMENT nam (\%extersion;)> $<$ IATTLIST nam \%direction; >

<!ELEMENT obj (\%extension;)> $<$ !ATTLIST obj \%direction; >

<EELEMENT opl (\%extension;)> $<$ !ATTLIST opl \%direction >

$<$ [ELEMENT or (\%extension;)> $<$ !ATTLIST or \%direction; >

<!ELEMENT per (\%extension;)> $<$ :ATTLIST per \%direction;

<!ELEMENT plc (\%extension;)> <!ATTLIST plc \%direction $<$ EELEMENT plf (\%extension;)> <!ATTLIST plf \%direction; >

$<$ LELEMENT pit (\%extension;)> $<$ IATTLIST plt \%direction; >

$<$ [ELEMENT pof (\%extension;)> $<$ IATTLIST pof \%direction; >

<!ELEMENT pos (\%extension;)> <!ATTLIST pos \%direction; >

$<$ ELLEMENT ptn (\%extension;)> <!ATTLIST ptn \%direction; >

<!ELEMENT pur (\%extension;)> <ATTLIST pur \%direction; >

<!ELEMENT qua (\%extersion;)> <IATTLIST qua \%direction; >

$<$ EELEMENT rsn (\%extension;)>

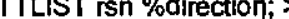

$<$ LELEMENT scn (\%extersion;)> 
$<$ !ELEMENT seq (\%exten\$ion;)>

$<$ IATTLIST seq \%direction; >

<IELEMENT src (\%extenslon;)>

<ATTLIST src \%direction; >

$<$ ELEMENT tim (\%extension;)>

<!ATTLIST tim \%direction; >

<!ELEMENT tmf (\%extension;)>

$<$ IATTLIST tmf \%direction $>$

$<$ ELLEMENT tmt (\%extension;)>

$<$ !ATTLIST tmt \%direction >

$<$ !ELEMENT to (\%extension;)>

$<$ !ATTLIST to \%direction; $>$

$<$ !ELEMENT via (\%extension;) >

$<$ IATTLIST via \%direction; >

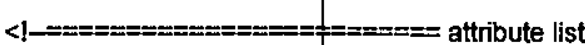

$<$ !ELEMENT tense EMPTY>

$<$ :ATTLIST tense

attribute (past | presen | future) \#REQUIRED>

$<$ !ELEMENT aspect EMPTY>

$<$ IATTLiST aspect

attribute (begin-soon | begin-just | progress | end-soon | end-just | compiete | state ( repeat) \#REQUIRED>

$<$ IELEMENT reference EMPTY>

$<$ !ATTLIST reference

attribute (generic | def | indef | not | order) \#REQUiRED>

$<$ !ELEMENT focus EMPTY>

$<$ !ATTLIST focus

attribute (emphasis | entry | qfocus | theme | title | topic) \#REQUiRED>

$<$ lELEMENT attitudes EMPTY>

$<$ IATTLiST attitudes

attribute (affirmative | confirmation | exclamation | imperative | interrogative | invitation ( politeness | respect | vocative) \#REQUIRED>

$<$ !ELEMENT viewpoint EMPTYY

$<$ IATTLIST viewpoint

attribute (ability | ability-past | apodosis-real | apodosis-unreal | apodosis-cond | conclusion | custom | expectation / grant | grant-not | insistence | intention | inevitability | may | obligation | obligation-not | possibility | probability | should | unexpected-presumption / unexpected-consequence ( will) \#REQUIRED>

<!ELEMENT convention EMPTY>

$<$ IATTLIST convention

attribute (angle_bracket | double_parenthesis | double_quotation | parenthesis | pl | single_quotation | square_bracket) \#REQUIRED> 


\section{BIBLIOGRAFIA}

(ARPA, 1993)

(Bray et. al., 2000)

(Brown, 1989)

(Cohen \& Levesque, 1990b)

(Cohen \& Levesque, 1995)

(Connolly, 2000)

(Courtois \& Silberztein, 1990)

(David, 1999)

(Davis \& Smith, 1983)

(Dignum, 2000)
Knowledge Sharing Initiative ARPA. The Knowledge sharing effort approach. UMBC agent Web, 1993. Disponivel on-line: http://www.cs.umbc.edu/agents

Bray, T.; Paoli, J.; Sperberg-McQueen, C. M. Extensible Markup Language (XML) 1.0. (Second Edition) Outubro 2000. Disponivel on-line: http://www.w3.org/TR/REC-xml

Brown, H. Standard for Structured Documents. The Computer Journal, v.32, n.6, p.505-514, 1989.

Cohen, P. R., and Levesque, H. J. Performatives in a rationally based speech act theory. In Proceedings of the 28 th Annual Meeting of the Association for Computational Linguistics, Pittsburgh, Pennsylvania. 1990b.

Cohen, Philip R; Levesque Hector. Communicative Actions for Artificial Agents, p.419-436. AAAI press/The MIT press, Junho 1995. J. M.

Connolly, D. Extensible Markenp Language (XML). Fevereiro 2000. Disponivel on-line: http://www.w3.org/XML/

Courtois, B., and Silberztein, M. (Eds.). Dictionnaires électroniques $d u$ franfais. Langue française, 87, 1-127. 1990

David Reilly, Agent Communication., Fevereiro 1999. Disponível on-line:

http://www.webdevelopersjournal.com/articles/agent_commun ication.html

Randal Davis and Smith. Negotiation as a metaphor for distributed problem solving. Artificial Intelligence, 20:63-109, 1983

Dignum, Frank; Greaves, Mark. (ed.). Issues in agent communication. - (Lecture notes in computer science; Vol 1916: Lecture notes in artificial intelligence) Berlin; Heidelberg; New York; Barcelona; Hong Kong; London; Milan; Paris; Singapore; Tokyo: Springer, 2000 . 
(Embury \& Gray, 1995)

(Farquhar et. al., 1995)

(Finin et al., 1993)

(FIPA, 1999)

(Franklin \& Graesser, 1996)

(Fraser et. al., 1995)

(Fuchs \& Wheadon,

(Gómez-Pérez, 1995)

(Gómez-Pérez, 1990)

(Gouveia et al., 1998)

(Gómez-Pérez et. al. 1995)
Embury, S.; Gray, P. compiling a declarative high-level language for semantic integrity constraints. Technical Report AUCS/TR9506, University of Aberden, 1995.

Farquhar, A; Fikes, R; Pratt, W.; rice, J. Collaborative ontology construction for information integration. Technical teport KSL-95-63, Stanford University Knowledge Systems Laboratory, 1995.

Finin, Tim; Yannis Labrou; Mayfield, James. KQML as an Agent Communication Language, p.291-315. AAAI press/The MIT press, 1993.

Foundation for Intelligent Physical Agents FIPA. Fipa spec 2 agent communication language. Technical Report Draft, version 0.1, Foundation for Intelligent Physical Agents, 1999, Disponivel online: http://www.fipa.org/spec/fipa99.html

Franklin, S.; Graesser, A. Is it an agent or Just a Program?: $A$ Taxonomy for Autonomous Agents. In Proceedings of the Third International Workshop on Agent Theories, Architectures and Languages, $1996 . \quad$ Disponível on-line: http://www.msci.memphis.edu/ franklin/AgentProg.html.

Fraser. J., A. Tate, and M.Uschold. The enterprise toolset - an open enterprise architecture. In the Impact of Ontologies on Reuse, Interoperability and Distributed Processing, pages 42-50. Unicom Seminars, London, 1995. Further information about the Enterprise Project and Ontology is available on the World Wide Web from : http://www.aiai.ed.ac.uk/ enterprise/enterprise.

Fuchs, J.; Wheadon, J. Prospective applications of ontologies for future space missions. In The Impact of Ontologies on Reuse, Interoperability and Distributed Processing, p83-96. Unicom Seminats, London, 1995.

Gómez-Pérez, a.; Juristo, N. Pazos, J. Evaluation and assessment of knowledge sharing technology. In N.J. Mats, editor, Towards Very Large Knowledge Bases - Knowledge Building and Knowledge sharing 1995, p289-296. IOS Press, Amsterdam, 1995.

Gómez-Pérez, A. Some ideas and examples to evaluate ontologies. In Proceedings of the Eleventh conference on Artificial Intelligence Applications. IEEE computer society Press, 1995.

Gómez-Pérez, A. Guidelines to verify completeness and consistency in ontologies. 1996. to appear at the Third World congress on Expert Systems.

Gouveia, D; Neto, A. B.; Silva, M. J. ACE:Um Agente de compras na Internet. XII Simpósio Brasileiro de Engenharia de Software, Anais, p.281-296, 1998. 
(Grosof \& Labrou, 1999)

(Gruber, 1993)

(Gruber, 1995)

(Gruninger \& Fox, 1995)

(Idris, 1999)

(Jennings \& Wooldridge, 1995)

(Johnson, 1999)

(Jones et. al, 1995)

(Ketchpel \& Genesereth, 1994)

(Labrou \& Finin, 1997a)
Grosof, Benjamin N.; Labrou, Yannis. An Approach to using XML and a Rule-based Content Language with an agent communication Language. IBM Research Report. RC 21491 (96965), 28 May 1999, Disponivel on-line: http://www.research.ibm.com

Gruber, T. A translation approach to portable ontology specifications. Knowledge Acquisition, 5(2): 199-220, 1993.

Gruber, T. Towards principles for the design of ontologies used for knowledge sharing. International Journal of Human-Computer Studies, 43(5/6):907-928, 1995

Gruninger M.; Fox, M. S. Methodology for the design and evaluation of ontologies. In Workshop on Basic Ontological Issues in Knowledge Sharing. International Joint Conference on Artificial Intelligence, 1995.

Guarino, P. Giaretta, P. Ontologies and knowledge bases - towards a terminalogical clarification. In N. J. Mars, editor, Towards Very Large Knowledge Bases - Knowledge Building and Knowledge Sharing 1995, p.25-35. IOS Press, Amsterdam. 1995.

Idris, N. Should I use SAX or DOM? Maio 1999. http://developerlife.com/saxvsdom/default.htm

Jennings, N. R.; Wooldrige, M. Agent Theories, Architectures, and Languages: a Survey. Intelligent Agents, p.55-67, 1995.

Johnson, M. XML for the Absolute Beginner. Disponivel on-line: http://www.javaworld.com/javaworld/jw-04-1999/jw-04xml.html. Abril 1999.

Jones, M.; Wheadon, J.; Whitgift, D.; Niezatte, M.; Timmermans, R.; Rodriguez, I.; Romero, R. An agent based approach to spacecraft mission operations. In N.J. Mars, editor, Towards Very Large Knowledges Bases - Knowledge Building and Knowledge sharing 1995, p259-269. IOS Press, Amsterdam, 1995.

Ketchpel, S.; Genesereth, M. Software Agents. Communications of ACM, Vol37, Nro 7, p.48-53, julho de 1994.

Labrou, Y.; Finin, T. A proposal for a new kegml specification. Technical Report TR-CS-97-03, University of Maryland, Baltimore Country (UMBC), Disponivel on-line: http://www.cs.umbc.edu/kqml/papers, 1997. 
(Labrou et. al., 1999)

(Lange \& Mitsuru, 1998)

(Lee et. al., 1995)

(Lenat, 1995)

(Mace et al., 1998)

(Maes, 1994)

(Mamadou et al., 2000)

(McGrath, 1999)

(Megginson, 1998)

(Miller, 1995b)

(Moreira \& Walczowski, 1997)

(Mueller, 1998)

(Nunes et. al., 1999)

(Nunes, et.al., 1997)
Labrou; Yannis; Finin, Tim; Yun Peng. Agent Communication Languages: The Current Landscape. IEEE Intelligents Systems, p4552, March/April 1999.

Lange, D.; Mitsuru, O. Programming and Deploying Java Mobile Agents with Aglet. Addison Wesley, August 1998. ISBN-0-20132582-9.

Lee J., Yost G., PIF Working Group. The pif process interchange format and framework. Technical Report 180, MIT Center for Coordination Science, 1995.

Lenat, D. B. CYC: $A$ large-scale investment in knowledge infrastructure. Communications of the ACM, 38(11), 33-48. 1995

Mace, S.; Flohr, V.; Dobson, R.; Graham, T. Weaving a Better Web.Byte, p58-68, Março 23, 1998.

Maes, P. Agents that Reduce Work and Information Overload. Communication of the ACM, p.31-40, julho de 1994.

Mamadou, T. K; Shimazu, A.; Tatsuo, N. The State of the Art in Agent Communication Languages. Japan Advanced Institute of Science and Technology., Japan, 1999.

McGrath, S. XML Aplicafões Práticas - Como Desenvolver Aplicafões de Comércio Eletrónico. Editora Campus, 1999.

Megginson, D. SAX 1.0: The Simple API for XML. Maio 1998. http://www.megginson.com/SAX/SAX1/index.html

Miller, G. A. WordNet: $A$ lexical database for English. Communications of the ACM, 38(11), 39-48. 1995.

Moreira, D. A.; Walczowski, L. T. Using Software Agents to Generate VLSI Layouts. IEEE Expert Intelligent Systems, p.26-32. Nov/Dez. de 1997.

Mueller, Erik T. Natural Language processing with ThughtTreasure. New York: Signiform. Disponível on-line:

http://www.signiform.com/tt/book/

Nunes, M.G.V.; Dias da Silva, B.C.; Pino, L.H.M.; Novais de Oliveira Jr, O; Martins, R.T.; Montilla, Gisele. Introdução ao Processamento das Línguas Naturais, N38, Notas didácticas do ICMC, São Carlos, Junho 1999.

Nunes, M.G.V.; Sossolote, C.R.C.; Zavaglia, C.; Rino, L.H.M. As Manifestações Morfosintácticas da Linguagem UNL no Portugês do Brasil. Nilc-97-TR-2, Série de Relatórios do Núcleo Interinstitucional de Linguistica Computacional. 28 de Outubro de 1997. 
(Parks, 1997)

Parks, D. Agent-oriented programming: A practical evaluation. Technical Report 94720, University of California Berkley, Disponível on-line: http://http.cs.berkley.edu/davidp/cs263/, 1997.

Pimentel, M.G.C., Teixeira, C. ${ }^{\mathrm{a} C}$ C., Pinto, C. C. - Hiperdocumentos Estruturados na WWW: Teoria e Prática. IN: XVIII Jornada de Atualização em Informática. JAI99 -SBC. Julho de 1999. p. 367424.

(Sadek et al., 1997)

(Schreiber et. Al, 1995)

(Shoham, 1993)

(Sierra et. Al., 2000)

(Singh, 1998)

(Singh, 1999)

(Skuce, 1995)

(SOAP, 2000)

(Sun, 2001)

(Torrance, 1998)
Sadek, D.; Bretier, P.; Panaget, F. France telecom artimis technology, arcol agent communication language and $m c p$, cap and sap agent's cooperativeness protocols. Technical report, FIPA, Disponivel on-line: http://drogo.cselt.stet.it/ fipa/cfp1/propos97.htm,1997

Schreiber, G; Wielinga, B.; Jansweijer, W. The kactus view on the 'o'word. In workshop on Basic Ontological Issues in Knowledge sharing. International Joint Conference on Artificial Intelligence, 1995

Shoham, Y. Agent-oriented programming. $\square$ ichael $\square$ al Intelligence, 60(1), p.51-92, 1993.

Sierra, Carles; Wooldridge, Dichael; Sadeh, Norman. Agent Research and Development in Europe. IEEE Internet computing, p81-83, September/October 2000.

Singh, M. P. Agent communication languages: Retbinking the principles. IEEE Computer, 31(12), p.40-47, December 1998.

Singh, M. P. A Social Semantics for Agent Communication Languages. ACM Press, August 1999. Stockholm, Sweden.

Skuce, D. Conventions for reacbing agreement on shared ontologies. In Proceedings of the $9^{\text {th }}$ Knowledge Acquisition for Knowledge Based Systems Workshop, 1995

Technical Report : SOAP - Simple Object Access Protocol 1.1, World Wide Web Consortium (W3C) disponivel on-line:

http://www.w3.org/TR/SOAP/

Specifications Java API for XML Processing Specification, final Version 1.1. disponivel on-line:

http://java.sun.com/xml/download.html

Torrance, M. Agent-0: $A$ language for agent oriented programming, 1998 Disponivel on-line: http://www.scs.ryerson.ca/drimsha/courses/cps720/agent0.ht $\mathrm{ml}$ 
(Trindade, 1997)

(Uchida, 1999)

(Ushold \& Gruningef, 1996)

(White, 1994)

(Wielinga et. al, 1994)

(XSL, 2000)

(Yokoi, 1995)
Trindade, C. C. Minimal Hyperlink Documents: Especificafão e Apresentagão de Estruturas Clásicas de Hipertextos. São Carlos, Dissertação (Mestrado) - Instituto de Ciências Matemáticas e de Computação, Universidade de São Paulo.

Uchida, H.; Zhu Meiying; Della Senta, T. (1999). Universal Networking Language: a gift for amillenium. Tokyo: United Nations University. Disponível on-line: http://www.unl.ias.unu.edu/publications/index.html Uschold, M. Gruninger, M. Ontologies: Principles, Methods and Applications. Knowledge Engineering Review, v.11, Number 2, June 1996. University of Edinburgh, 1996.

White, E. J. Telescript technology: The foundation for the electronic marketplace. Technical report, Genetal Magic, Inc., Disponivel on-line: http://www.generalmagic.com/technology, 1994.

Wielinga, R; Schreiber, G; Jansweijer, W; Anjewierden, A; van Hamelen F. Framework and formalism for expressing ontologies. Technical report, University of Amsterdam, 1994. Esprit Project 8145 Deliverable DO1b1, Disponivel on-line: http://www.swi.psy.uva.nl/projects/Kactus/Reports.html

Learning XSL. [online]. Disponivel na Internet em: www.w3.org/Style/XSL. 2000.

Yokoi, T. The EDR electronic dictionary. Communications of the ACM, 38(11), 42-48. 1995. 